UNIVERSIDADE DE SÃO PAULO

FACULDADE DE FILOSOFIA, LETRAS E CIÊNCIAS HUMANAS

DEPARTAMENTO DE ANTROPOLOGIA

PROGRAMA DE PÓS-GRADUAÇÃO EM ANTROPOLOGIA SOCIAL

\author{
Alvaro Antônio Russo Júnior
}

NA BOCA DA MATA:

Diálogos entre santo daime e umbanda

Dissertação apresentada à Universidade de São Paulo, como parte das exigências do Programa de Pós-Graduação em Antropologia Social, para obtenção do título de mestre.

Orientador: Prof. Dr. Vagner Gonçalves da Silva

Versão Corrigida

São Paulo

Fevereiro de 2016 


\title{
NA BOCA DA MATA: Diálogos entre santo daime e umbanda \\ Resumo
}

Esse estudo tem como principal objetivo a análise de rituais afro-brasileiros que utilizam a bebida sacramental denominada daime e concepções relativas à doutrina religiosa do santo daime, uma religião ayahuasqueira brasileira. O diálogo entre dois sistemas religiosos, santo daime e umbanda, manifesta-se de forma pronunciada através de rituais específicos denominados giras com daime, que serão privilegiados nesta pesquisa. A partir de uma abordagem do espaço e das práticas rituais, da musicalidade, do panteão e do transe religioso pretende-se evidenciar as concepções do grupo religioso e demonstrar como essa ontologia opera a partir de um princípio transformacional. Busca-se neste trabalho compreender onde e como tais transformações ocorrem e, dessa forma, compreender como a prática ritual pode iluminar a concepção do ser característica dos grupos que realizam esses rituais.

Palavras chave: ayahuasca, daime, gira, santo daime, umbanda

\section{ON THE EDGE OF THE WILD: Dialogues between santo daime and umbanda}

\begin{abstract}
This research aims to analyse afro Brazilian rituals that engage the sacramental beverage called daime and conceptions from the religious doctrine of santo daime, a Brazilian ayahuasca religion. The dialogue between two religious systems, santo daime and Umbanda, appears intensely throughout specific rites knowns as giras with daime, that are the main subject of this research. From an approach of spatiality and ritual practices, musicality, pantheon and religious trance, the religious groups' notions are highlighted unravelling how this ontology acts through a transformative principle. This account describes where and how those transformations happens and, therefore, how the ritual practice can enlighten the particular notion of being among these groups that carry on those rituals.
\end{abstract}

Key words: ayahuasca, daime, gira, santo daime, umbanda 
RUSSO JR, Alvaro Antônio. Na Boca da Mata: Diálogos entre santo daime e umbanda. Dissertação apresentada à Faculdade de Filosofia, Letras e Ciências Humanas da Universidade de São Paulo como pré-requisito para obtenção do título de Mestre em Ciência Social (Antropologia Social)

Banca examinadora:

Aprovada em: 


\section{Agradecimentos}

A realização dessa pesquisa não seria possível sem a contribuição de algumas pessoas que de diferentes formas também estão presentes nesse trabalho. Agradeço aos responsáveis pelos centros religiosos onde realizei as observações que sempre me receberam de forma muito calorosa e acolhedora: Natalina Borges, Gê Marques, Dalmo Ribas, Jorge Scritori e Jamil Rachid. Essa pesquisa também não seria possível sem a inestimável contribuição de algumas pessoas que se dispuseram a compartilhar suas experiências espirituais e sua trajetória de vida comigo. Deixo aqui um agradecimento especial ao meu amigo Henrique Yokote, que me apresentou ao mundo Astral, e a sua esposa, Bia de Jesus, que ofereceu contribuições inestimáveis para essa pesquisa. Agradeço também a Eduardo Lenon e Regiane Almeida que me acompanham há bastante tempo nessa jornada. Sou imensamente grato pela amável recepção da madrinha Brilhante, de sua família e dos moradores da comunidade do Céu do Mapiá. Desejo também agradecer a Clara Yura por compartilhar gentilmente seu conhecimento sobre espiritualidade, que foram fundamentais para realização dessa pesquisa. Agradeço a Marcelo Mercante, sobretudo por sua leitura cuidadosa e por ter me apresentado à barquinha. Aos meus amigos Guilherme Meneses, Ana Fiori, Alice Haibara, Nadja Marin e Carlos Nascimento por me acompanharem na floresta acreana. Agradeço a Fernando Aquino pelo compartilhamento de suas experiências e indicações que auxiliaram nos rumos dessa pesquisa, a Frederico Reis e a Luiz Pellon pela amável recepção na igreja Flor da Montanha. Agradeço a querida Ana Paula Morel por ter tornado real o desejo de conhecer as giras de Lumiar e por todo seu apoio, ao qual serei eternamente grato. Agradeço ao meu orientador Vagner Gonçalves da Silva, pela sua paciência e inestimável contribuição para a construção dessa pesquisa. Agradeço aos professores Marina Vanzolini, Edward MacRae e Julia Sauma pela leitura atenta e pelas valiosas observações nas bancas de qualificação e de defesa da dissertação. Agradeço também aos inúmeros frequentadores desses centros que, de diferentes maneiras, me ajudaram durante a pesquisa e que cometo aqui a injustiça de não conseguir nomeá-los. Essa pesquisa também lhes pertence. 
Na boca da mata

Tem chave de ouro

Tem pedras de prata

E aves de agouro

Tem um doce mistério

Que eu não sei contar

Só sei dizer pra você

Que meu pai mora lá

(Jovelina P. Negra, Labre e Carlito Cavalcante. Água de Cachoeira)

É na boca da mata

É na boca da mata que eles moram

Quando os caboclos se despedem

E vão embora

(Ponto de umbanda. Autor desconhecido) 


\section{Sumário}

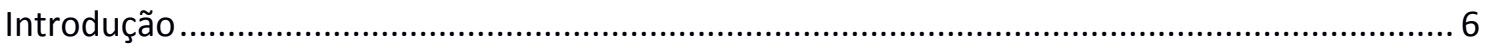

Santo daime, catolicismo popular e religiões afro-brasileiras ................................................. 11

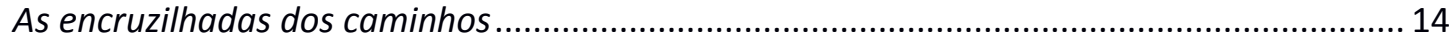

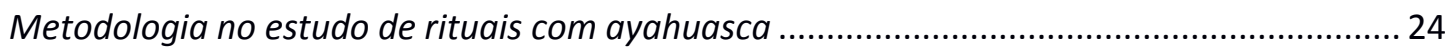

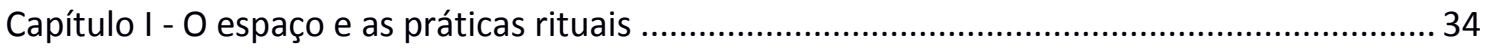

Quando a estrela vira o congá, ou o congá vira a estrela: uma análise do espaço ritual .......34

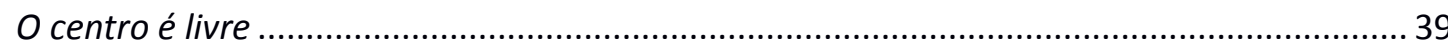

Santo daime e umbanda para trabalhar - uma análise dos ritos........................................... 41

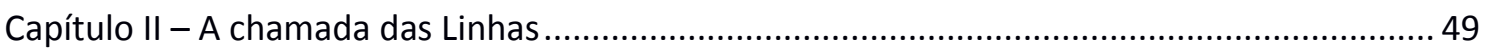

O dono do ponto é o guia, o hino tem autoria - uma análise da música e da dança.............. 49

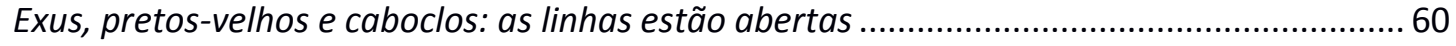

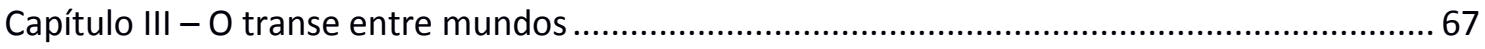

As interpretações acerca do transe nas religiões afro-brasileiras: breve panorama................67 67

Breve panorama sobre a abordagem do transe nas religiões ayahuasqueiras ....................... 74

A umbanda ensina abrir a porta, o daime abre - uma análise da experiência ........................ 83

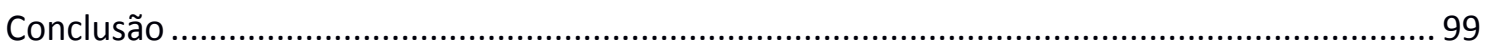

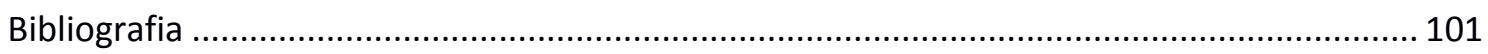




\section{Introdução}

Esse estudo tem como principal objetivo a análise de rituais afro-brasileiros que utilizam a bebida sacramental denominada daime, bem como concepções relativas à doutrina religiosa do santo daime, uma religião ayahuasqueira brasileira. Em alguns dos grupos analisados, este encontro entre dois sistemas religiosos, santo daime e umbanda, manifesta-se de forma mais pronunciada através de rituais específicos que serão privilegiados na abordagem analítica. Atualmente, tal manifestação religiosa não pode ainda ser considerada representativa em termos quantitativos no campo religioso afrobrasileiro, por se tratar de práticas e rituais relativamente recentes quando atentamos ao longo processo histórico das religiões no seio das quais essa transformação se manifesta. Acredita-se, porém, que o presente estudo se justifica pela relevância que tais rituais apresentam para os diálogos inter-religiosos, sobretudo entre as denominações de origem amazônica, com forte influência cabocla, e aquelas surgidas no contexto das grandes cidades do Sudeste, com forte influência das religiões africanas.

Emprega-se, neste caso, o termo nativo caboclo, para referir-se às populações ribeirinhas e agroextrativistas situadas no piemonte amazônico. $\mathrm{O}$ termo, quando utilizado fora de contexto religioso, define populações extremamente variadas remetendo, quase sempre, aos antigos habitantes da terra ou de uma região geográfica específica. O termo caboclo, por possuir uso bastante vasto dentro e fora do contexto religioso em praticamente todo o território nacional, merece certa atenção com relação a suas utilizações podendo, sobretudo, ser interpretado como uma categoria ontológica que decorre em grande medida de um diálogo, nem sempre pacífico, com os povos ameríndios e africanos.

Esse encontro entre populações caboclas, indígenas e também africanas, de diferentes maneiras e envolvendo distintas concepções do ser, revestem essa noção de uma complexidade e, talvez por isso mesmo, coloque-a como objeto privilegiado para a compreensão de questões afroindígenas em determinados contextos. O fato de uma noção como essa ser construída, em grande parte dos casos, por uma negação ontológica sugerindo que o caboclo não é indígena e também não é remanescente de populações africanas remete, sobretudo, a imprecisão de categorias com que essas populações são tratadas pela sociedade englobante que, atrelada a uma ideia de impureza do ser, parece 
querer impor que não se trata de populações suficientemente indígenas e suficientemente africanas.

Os referidos rituais aos quais este estudo se dedica ocorrem tanto em terreiros de umbanda quanto em igrejas de santo daime, porém com idiossincrasias correspondentes a cada local de culto e a trajetória de cada liderança religiosa e sua consequente inserção em uma rede místico-política. Foram três os centros religiosos observados para a realização dessa pesquisa, todos eles localizados na cidade de São Paulo, que dividem-se da seguinte maneira: dois centros umbandistas e um centro daimista, denominados na respectiva ordem: Templo Sagrado Jesus de Nazaré São João Batista-Caboclo Sete Pedreiras; Instituto Cultural Sete Porteiras do Brasil; Reino do Sol. A observação dos rituais concentrou-se, no decorrer da pesquisa, no Reino do Sol e no Sete Pedreiras, como serão definidos de agora em diante. Embora tenha-se dedicado a dois centros religiosos, a pesquisa proporcionou a observação de rituais em outros centros religiosos, sobretudo terreiros, igrejas de santo daime e da barquinha ${ }^{1}$ dos quais destacam-se, respectivamente: Templo de Umbanda São Benedito em São Paulo/SP; Flor da Montanha em Lumiar/RJ; Centro Espírita Obras de Caridade Príncipe Espadarte em Rio Branco/AC.

Não existe, entre as lideranças e os adeptos dos centros estudados, um consenso sobre a terminologia utilizada para denominar os rituais em questão. O termo umbandaime $^{2}$, apesar de bastante difundido para denominar tais rituais, no âmbito das práticas religiosas que articulam santo daime e umbanda, em muitos centros espalhados pelo Brasil, encontra certa resistência em outros centros, como é o caso da igreja de santo daime objeto desse estudo. Em alguns casos, como na igreja observada durante a pesquisa, opta-se pela designação giras ${ }^{3}$ com daime, ou apenas giras. A designação gira delimita uma fronteira de pertencimento religioso que marca diferentes tradições ou linhas de estudo que, dependendo do ponto de vista de quem opera tal classificação, podem assumir uma forma ou outra, porém nos dois casos tratam-se de rituais de

\footnotetext{
1 A barquinha é considerada uma das três matrizes das religiões ayahuasqueiras e possui um intenso diálogo com sistemas religiosos afro-brasileiros possuindo, inclusive, a realização de giras com daime em seu calendário.

2 O termo umbandaime encontra-se atualmente relativamente difundido, sendo utilizado em diversas cidades brasileiras e também por membros da igreja sede da doutrina Céu do Mapiá, no estado do Amazonas. (Clara Yura, comunicação pessoal)

${ }^{3}$ Gira é o nome dado à sessão de trabalho espiritual realizada nos terreiros de umbanda. (Silva, 1994)
} 
umbanda com daime. Como se tratam de perspectivas diferentes, porém situadas no escopo do diálogo entre santo daime e umbanda, procura-se pensá-las em conjunto, atribuindo continuidades e contrastes entre os ritos para fins analíticos.

Entre os três centros religiosos que foram definidos como objeto dessa pesquisa, apenas dois possuem rituais denominados como umbandaime em seus calendários: o Templo Sagrado Jesus de Nazaré São João Batista-Caboclo Sete Pedreiras e o Instituto Cultural Sete Porteiras do Brasil. O Templo de Umbanda São Benedito recebe em seu espaço adeptos e lideranças do Reino do Sol para realização de rituais denominados atendimentos. A igreja Reino do Sol, por sua vez, designa os estudos rituais da linha umbandista realizados em seu centro como giras com daime, ou apenas giras.

Situado na Rua Brasópolis, n 200, no bairro São Judas, o terreiro Caboclo Sete Pedreiras realiza rituais de "desobsessão" aos sábados e, aos domingos, os rituais com daime alternam-se semanalmente entre umbandaime e outros "trabalhos" calendário do santo daime, sobretudo "concentrações" e "curas" . O terreiro em questão encontra-se abrigado em um sobrado de dimensões modestas cujos cômodos na parte inferior serviam de moradia à mãe-de-santo ou madrinha Natalina Borges. O termo madrinha é uma classificação atribuída às lideranças religiosas femininas do santo daime, que Natalina passa a adotar em substituição à antiga classificação de mãe de santo, termo utilizado para denominar a liderança espiritual da umbanda e do candomblé, mas que acabam coexistindo, dependendo do contexto, sem gerar desatinos.

O segundo terreiro a compor o objeto dessa pesquisa é o Instituto Cultural Sete Porteiras do Brasil, localizado na Avenida Tiradentes 1290, no bairro do Bom Retiro. Fundado em 2006 por Jorge Scritori, o espaço ritual situa-se no andar superior de um prédio onde funciona uma agência bancária, sendo o acesso da rua feito por uma discreta porta de ferro ao lado do estabelecimento bancário. No ano de 2008 passou a

\footnotetext{
${ }^{4}$ Os rituais de desobsessão constituem a "maneira de trabalhar" de madrinha Natalina que os aprendeu com sua mãe. $\mathrm{O}$ ritual tem por finalidade afastar os espíritos obsessores através de passes mágicos que visam descarregar o consulente através da manipulação das energias negativas. (Comunicação pessoal, jan. 2010)

${ }^{5}$ Trabalho possui o mesmo significado seja no sistema umbandista, seja no sistema daimista. É um sinônimo para ritual, sessão espiritual ou culto religioso. (Silva, 1994)

${ }^{6}$ Concentração e Cura são rituais formatados pelo Mestre Irineu (ver abaixo) e que posteriormente receberam algumas modificações pelo CEFLURIS, grupo do Padrinho Sebastião. São realizados atualmente pelo CEFLURIS e possuem hinários específicos, podendo sofrer pequenas variações de acordo com o centro religioso onde é realizado. (Labate, 2002).
} 
introduzir a bebida sacramental e algumas práticas do santo daime em seu terreiro. Inicialmente os rituais eram reservados ao corpo mediúnico no formato de Concentrações e, após dois anos nesse formato, iniciou uma aproximação ritual maior entre as duas religiões, que se deu através da participação sistemática dos membros do terreiro em giras do Reino do Sol durante certo período e culminou na realização de algumas giras com daime no próprio centro.

O terceiro centro a compor este estudo é a igreja de santo daime Reino do Sol, situada no sítio São Francisco, na Rua Henrique Hessel, 1551, Parelheiros. O sacerdote responsável, Antônio Marques Alves Júnior ou Gê Marques, como é conhecido, conta que a igreja se consolidou no sítio onde atualmente se encontra há aproximadamente 12 anos. Antes desse período, o Reino do Sol, que ainda não possuía esse nome, constituíase enquanto um grupo de pessoas que não encontrava espaço nos ritos do santo daime para manifestação da "mediunidade", e se reuniam em um salão cedido pela igreja daimista Céu da Nova Era, situada em São Lourenço da Serra, para realizar essa prática.

Gê Marques via a necessidade de se tratar a incorporação em outros moldes que o modelo daimista não permitia realizar. Tem início então, nessa época, o desenvolvimento das giras com daime, sem a pretensão de se formar uma igreja ou sequer seguir o calendário ritual do santo daime.

Para entender o diálogo inter-religioso realizado pelo Reino do Sol faz-se necessário a análise das práticas rituais desse grupo em outro espaço, o Templo de Umbanda São Benedito, sob a liderança espiritual de pai Jamil Rachid. O grupo de Gê Marques possui grande proximidade com este terreiro, realizando trabalhos de atendimento mediúnico, sem a ingestão de daime, com frequência semanal há aproximadamente quatro anos.

Nos centros estudados foram encontrados desde rituais bastante consolidados, como as giras do Reino do Sol, até uma experiência única que envolveu a ingestão de daime no terreiro Sete Porteiras, em 2011, e que não voltou a se repetir, demonstrando um caráter ainda incipiente do diálogo entre as duas religiões neste espaço. Diferentes formas e níveis de aproximação vêm sendo realizadas entre santo daime e umbanda na

\footnotetext{
${ }^{7}$ Categoria nativa utilizada para definir a faculdade de incorporação que um médium possui. Diz-se médium desenvolvido aquele que é capacitado a controlar as incorporações com bastante desenvoltura. (Comunicação pessoal, março 2012)
} 
cidade de São Paulo e em outras cidades, dada a porosidade das duas manifestações religiosas que compõem o objeto desse estudo.

O santo daime é considerado uma das 3 matrizes das chamadas religiões ayahuasqueiras. A designação religião ayahuasqueira refere-se aos movimentos religiosos originários da Amazônia brasileira que fazem o uso ritual da ayahuasca, mas na maioria dos casos em que o termo religiões ayahuasqueiras é empregado, está se fazendo referência a 3 matrizes religiosas: santo daime; barquinha e união do vegetal (UDV) (Labate, 2002). Santo daime será a forma utilizada para fazer referência a dois grupos religiosos: o Alto Santo - fundado por Raimundo Irineu Serra, o mestre Irineu, e também à dissidência do grupo do Padrinho Sebastião Mota de Melo, conhecida pela sigla CEFLURIS (Centro Eclético da Fluente Luz Universal Raimundo Irineu Serra). Santo daime, ou apenas daime, é a forma como refere-se também a bebida sacramental utilizada nos rituais no sistema religioso do santo daime e também da barquinha.

Conforme apontado por Labate (2002), na produção textual a respeito das religiões ayahuasqueiras pode-se notar que os primeiros estudos eram voltados principalmente aos aspectos históricos, culturais e simbólicos dos grupos ayahuasqueiros, considerados matrizes da subsequente expansão do uso ritual da ayahuasca. O termo ayahuasca, de origem quéchua, foi o nome com que a bebida se consolidou em grande parte dos trabalhos acadêmicos, especialmente entre antropólogos. Encontra-se como possível tradução a designação "cipó das almas", mas recebe outros inúmeros nomes dependendo do contexto sociocultural em questão. (Labate, 2002)

Dessa forma, o uso ritual da ayahuasca transitando nacional e internacionalmente em diferentes apropriações se apresenta como campo profícuo para a compreensão dos diálogos e das novas concepções sobre religião que derivam desses desdobramentos. É justamente sobre esses novos diálogos, sejam eles inter-religiosos, sejam eles entre a religião e a sociedade englobante ou ainda entre as diversas áreas do conhecimento mobilizadas para apreender esse campo de estudos que a produção intelectual sobre as religiões ayahuasqueiras tem se dedicado nos últimos anos (Labate, 2008). 


\section{Santo daime, catolicismo popular e religiões afro-brasileiras}

A aproximação que ocorreu na década de 1930 entre o catolicismo popular, já embebido da influência de sistemas africanos, e o uso ritual da ayahuasca de comunidades ameríndias, é denominada por culto ao santo daime, que é ao mesmo tempo nome da bebida e da doutrina religiosa. Não se tratam de sistemas puros no sentido de matrizes originárias posto que, após séculos de interação e interpenetração entre concepções ameríndias, católicas e africanas, fica impossibilitada a delimitação de fronteiras rígidas de influência. Tal busca das origens pode ser perniciosa do ponto de vista antropológico, pois tais buscas normalmente acabam por inferir, mesmo que implicitamente, que algumas manifestações são mais "puras" e "preservadas" em contraposição a outras "descaracterizadas" ou "impuras".

Para compreender o diálogo presente atualmente na doutrina do santo daime faz-se necessário evidenciar parte da trajetória de seu fundador, Raimundo Irineu Serra, que chegou ao Acre em 1912 aos 20 anos de idade, vindo do Maranhão e trazendo como bagagem suas experiências em práticas afro-brasileiras, sobretudo maranhenses, como a pajelança e o tambor de crioula (Labate, 2002). Dessa maneira, destaca-se o que nos centros estudados seria não apenas um encontro pontual, inédito e casual entre umbanda e santo daime, mas um novo encontro de sistemas em que alguns índices afrobrasileiros já estavam em um longo processo de interação.

Um primeiro encontro entre a umbanda, ou uma variação do que hoje se entende por esse culto, e práticas ayahuasqueiras amazônicas, é citado na bibliografia como pratica pioneiramente desenvolvida por Chica Macaxeira, em Porto Velho. Clodomir Monteiro da Silva sugere inclusive a influência desse terreiro como algo marcante na constituição do ainda nascente culto do santo daime nas décadas de 1930 e 1940 (Monteiro da Silva, 2002, p. 416).

No bojo da expansão incipiente do culto daimista para os centros urbanos do Sudeste no final da década de 70, ocorre um fato de considerável importância para o desenvolvimento do diálogo com as práticas umbandistas no santo daime. O encontro do Padrinho Sebastião Mota de Melo com o "macumbeiro" José Lito, alcunhado como Ceará, representou uma expressiva influência no conjunto de crenças do grupo religioso, estabelecido àquela época na colônia Cinco Mil, na periferia de Rio Branco (Marques Júnior, 2007; 145). 
Ceará engendra uma introdução de práticas afro-brasileiras na colônia Cinco Mil que configurariam um momento marcante no diálogo entre a doutrina do santo daime e os sistemas afro-brasileiros. Esse personagem histórico adquiriu relativa projeção dentro da comunidade daimista através de suas práticas afro-brasileiras. $\mathrm{O}$ termo "macumbeiro", atribuído à Ceará, está ligado à sua personalidade controversa que gerou com o tempo atritos e desavenças na colônia Cinco Mil, que resultaram em sua morte (Marques Júnior, 2007).

Outro momento historicamente importante, no que diz respeito a inserção da umbanda no santo daime, mais especificamente no grupo sob a liderança do Padrinho Sebastião, foi apontado por Marques Júnior (2007) como o início do intercâmbio realizado com jovens mochileiros, que levaram ao Acre elementos provenientes da umbanda carioca, sobretudo durante a década de 1970. Nesse intercâmbio religioso ocorrido entre Rio de Janeiro e o Acre, Baixinha, mãe de santo carioca, possui um papel de grande importância primeiramente por acolher práticas daimistas no terreiro Tata Ojú e, posteriormente, viajar até o Acre onde ajudou na consolidação das giras de umbanda na comunidade de padrinho Sebastião, com quem desenvolveu um profícuo diálogo.

$\mathrm{O}$ terceiro momento deste encontro das duas religiões seria marcado pelo falecimento do Padrinho Sebastião e sua substituição no comando do CEFLURIS pelo Padrinho Alfredo Gregório Mota de Melo, que oficializou esse diálogo através da elaboração de novos rituais e, dessa forma, um subsequente aumento da aceitação dessa interpenetração religiosa passa a ser incrementado desde o final da década de 1990 (2007, p. 133).

Paralelamente ao diálogo entre santo daime e umbanda vale ressaltar que, entre as religiões ayahuasqueiras, a barquinha também é caracterizada por um diálogo com os sistemas afro-brasileiros. Seu fundador, mestre Daniel Pereira de Mattos, depois de conhecer o Santo daime por volta de 1936 através de um convite do próprio mestre Irineu, opta por seguir seu próprio caminho estimulado pelo próprio fundador da doutrina daimista. Acaba, dessa forma, desenvolvendo um culto cujas práticas possuem ênfase ritual na prática da caridade envolvendo a incorporação de seres denominados "encantados" e de uma parte significativa do panteão umbandista representado, sobretudo por pretos-velhos e caboclos (Mercante, 2012).

A umbanda possui especificidades segundo a vertente ou a região onde é 
praticada, e cada centro religioso se revela possuidor de inúmeras idiossincrasias, como um caso singular das diferentes trajetórias e filiações a determinadas tradições religiosas que são acionadas no discurso e nas práticas religiosas. $\mathrm{O}$ termo terreiro, assim como ilê, abassá e roça designam o local de culto das divindades das religiões afro-brasileiras. Atualmente esses termos possuem relativa difusão entre os praticantes dessas religiões, mas isso nem sempre foi assim. Basta considerar a repercussão desse termo na primeira metade do século $\mathrm{XX}$, quando surgia nas grandes cidades do Sudeste a religião umbandista, acompanhada do fenômeno que se caracterizou por afastar determinados elementos tidos como africanos, ou seja, um embranquecimento declarado do sistema religioso. Isso pode ser notado, sobretudo na classificação das casas de culto, que tentava dissociar sua ligação com uma religiosidade africana tida como menos evoluída. Termos como templo, tenda, cabana e centro eram empregados em grande parte das casas que surgiram nesse contexto e muitos desses termos continuam sendo utilizados atualmente.

Nesse mesmo período, no início do século passado, mestre Irineu lançava as bases da religião daimista, que denominava suas casas de culto como igrejas. Nesse contexto, colocou-se o termo terreiro como um dos polos de um espectro cujo polo oposto seria a igreja. Essa classificação por parte do grupo daimista reflete, em certa medida, não apenas a contribuição marcante do catolicismo popular em seu sistema religioso, mas também uma forma de legitimar um grupo estigmatizado por suas práticas, de certa forma semelhante aos obstáculos enfrentados pela umbanda durante seu processo de legitimação.

Durante o processo de legitimação da umbanda, Dantas (1982) ressalta a importância do papel desempenhado pela organização institucional, como as federações, que visava intermediar o controle da polícia e, no plano ideológico, a tentativa de "limpá-las", sobretudo do estigma da feitiçaria, o que geralmente ocorria deslocando-se o estigma a outras práticas religiosas como a Quimbanda, colocadas em um polo oposto, deslegitimado e desqualificado.

O santo daime passa por um processo de legitimação semelhante, guardadas as devidas proporções. A doutrina ainda em processo de construção sofria com os estigmas sociais sobre a comunidade religiosa, por tratarem-se em sua maioria ex-seringueiros que perderam sua inserção econômica com o fim do ciclo da borracha, além de fazerem 
uso de uma bebida pouco conhecida e, talvez por isso, vítima de inúmeros preconceitos.

A rede de alianças estabelecidas por seu fundador contribui em grande medida para mediar a intervenção das forças policiais, o que de certa forma deve ser pensado como uma forma de diálogo e negociação que influenciaram os contornos do sistema religioso em elaboração. Ressalta-se, sobretudo, a relação místico-política que caracteriza as alianças fundamentais não redutíveis a um simples acordo entre lideranças políticas, sobretudo pelo teor dessas relações, pois em grande parte delas havia a precedência do reconhecimento de mestre Irineu como um grande curador. $\mathrm{O}$ título de curador, respaldado por sua comunidade, foi também responsável pela consolidação de inúmeros aliados políticos, em muitos casos inclusive com o recebimento de curas de ordem física e espiritual que exerceram um fator decisivo para o estabelecimento de importantes alianças.

A doutrina ainda em elaboração teve seus contornos traçados com distanciamento de práticas consideras "feitiços" ou até mesmo "demoníacas" associadas, sobretudo, ao uso do chá realizado pela cultura vegetalista dos caboclos amazônicos (MacRae, 1992) que, de acordo com MacRae e Moreira (2011), fomentava preconceitos tanto entre os contemporâneos aos primeiros contatos de mestre Irineu com a bebida como nos depoimentos atuais analisados por esse pesquisador.

Os primeiros contatos de mestre Irineu com a ayahuasca foram, de acordo com depoimentos recolhidos por MacRae e Moreira (2011), mediados pelos irmãos Costa nos arredores de Brasiléia, Acre. Esse mito do primeiro contato com a bebida surge nas narrativas analisadas pelo autor como a descrição de sucessivos encontros com vegetalistas peruanos, que passaram a ocupar uma posição antagônica em relação ao culto que Irineu iniciaria mais tarde. O culto de Irineu tendera, pelo menos no âmbito narrativo, a um distanciamento de práticas realizadas por brujos e hechiceros.

\section{As encruzilhadas dos caminhos}

Diante da relevância dos contrastes e continuidades estabelecidos no microcosmo das relações místico-políticas para a compreensão das idiossincrasias de cada casa de culto, propõem-se realizar uma descrição desses respectivos contextos a partir das narrativas das lideranças religiosas de cada um dos centros que compõem o 
objeto deste estudo que realizam diferentes diálogos entre a umbanda e o santo daime. Para esclarecer em que medida se dá essa intersecção entre os dois sistemas religiosos, farei a exposição da trajetória religiosa dos sacerdotes responsáveis pelos centros onde esse diálogo ocorre. Para construir essa trajetória religiosa individual que, de certa forma, lançará luz sobre a composição que possibilitou a formatação do culto realizado atualmente, serão utilizadas as entrevistas com os líderes religiosos que foram gentilmente concedidas para esta pesquisa.

Desses três centros religiosos, apenas dois possuem rituais denominados como umbandaime em seus calendários: o terreiro Templo Sagrado Jesus de Nazaré São João Batista-Caboclo Sete Pedreiras e o Instituto Cultural Sete Porteiras do Brasil. O terreiro Caboclo Sete Pedreiras realiza rituais de desobsessão ${ }^{8}$ aos sábados e, aos domingos, os rituais com daime são intercalados semanalmente entre umbandaime e trabalhos $^{9}$ referentes ao calendário do Santo daime, principalmente concentrações e curas ${ }^{10}$. As instalações físicas do centro religioso se resumem a um sobrado de dimensões modestas cujos cômodos na parte inferior serviam de moradia à mãe-de-santo ou madrinha, como também é chamada, Natalina.

Pode-se considerar este terreiro como o menor centro religioso que compõe este estudo, seja em dimensões físicas ou em número de frequentadores. O corpo de médiuns da casa era constituído por 6 pessoas, das quais apenas 3 participam dos rituais que envolvem o daime. O corpo de médiuns desse terreiro possui alta rotatividade, alterando-se por diversas ocasiões no decorrer do acompanhamento dedicado ao centro em questão. Os rituais possuem uma frequência de público bastante variável, o que dificulta o estabelecimento de um quórum médio de participantes, mas pode-se estabelecer uma faixa de variação compreendida entre 6 e 30 pessoas.

Madrinha Natalina é natural de São José do Rio Preto e chegou à cidade de São Paulo com idade aproximada de 17 anos. Ela teve os primeiros contatos com a

\footnotetext{
8 Os rituais de desobsessão constituem a "maneira de trabalhar" de madrinha Natalina que os aprendeu com sua mãe. O ritual tem por finalidade afastar os espíritos obsessores através de passes que visam descarregar o consulente através da manipulação das energias negativas.

9 Trabalho possui o mesmo significado seja no sistema umbandista, seja no sistema daimista. É um sinônimo para ritual, sessão espiritual ou culto religioso.

${ }^{10}$ Concentração e Cura são rituais formatados pelo Mestre Irineu e que posteriormente receberam algumas modificações pelo CEFLURIS, grupo do Padrinho Sebastião. São realizados atualmente pelo Alto Santo e pelo CEFLURIS e possuem hinários específicos, podendo sofrer pequenas variações de acordo com o centro religioso onde é realizado.
} 
mediunidade em sua própria família, possuindo influências marcantes de seu pai, que realizava rituais que ela define como um misto de candomblé e umbanda, e de sua mãe, que realizava consultas espirituais classificadas como atendimentos dentro de rituais denominados mesa branca.

Sua vidência manifestou-se cedo, com 7 anos, quando teve suas primeiras visões envolvendo Santa Rita de Cássia e Santa Teresinha. Frequentou outras manifestações religiosas como uma igreja pentecostal e posteriormente se tornou filha de Maria, buscando sempre, através dessas experiências, uma maneira de cessar sua clarividência que se tornara um incômodo. De acordo com sua própria interpretação, ela não se tornou mãe de santo, foi designada para essa ocupação através dos próprios orixás.

Segundo ela, seu processo de iniciação no candomblé foi equivocado, alegando ter sido "raspada ${ }^{11}$ errada" e, diante de um erro dessa magnitude, teve que lavar sua cabeça em uma cachoeira como medida paliativa para que não morresse, destino esse que ocorreu ao pai-de-santo responsável por sua iniciação. A madrinha alega já ter nascido feita ${ }^{12} \mathrm{e}$, nesse caso, não haveria a necessidade de se fazer o santo novamente.

Mãe Natalina trabalha há 40 anos em uma linha denominada desobsessão, na qual sua principal atuação é cuidar de pessoas loucas e com falsas loucuras, segundo ela. Afirma também já ter sido mãe de santo de 1500 filhos em seu antigo centro no Jabaquara. Esse período específico aparece em seu discurso como o apogeu, aparentemente econômico e espiritual, descrito como um momento em que se considerava "bem de vida". Na entrada de seu terreiro atual, recortes de jornal fixados na parede compõe um cenário nostálgico e contribuem de certa forma para certificar sua eficácia na cura da loucura, com destaque para uma manchete em que o Caboclo Sete Pedreiras é citado, em tom sensacionalista, como o responsável para desfazer uma determinada "macumba".

Seu contato com o daime ocorreu há aproximadamente 15 anos, entre 1998 e 1999, em seu próprio terreiro, através de um ex-filho de santo que lhe ofereceu o chá. A madrinha afirma, de forma contundente, que através dessa primeira experiência o

\footnotetext{
${ }^{11}$ Termo utilizado por adeptos do Candomblé para designar a iniciação na religião.

12 Ser feito ou feito no santo são designações recorrentes, sobretudo em alguns candomblés, para fazer referência ao processo iniciático, a própria feitura do santo.
} 
potencial da bebida ficou evidente e afirmou inclusive que essa bebida, o daime, expande muito a vidência e a clarividência, faculdades essas que ela já possui por conta de suas experiências espirituais anteriores. Nesse seu primeiro contato com a bebida é ressaltado o caráter de transcendência, até certo ponto inédito, quando afirma ter vislumbrado a presença simultânea de inúmeros orixás no quarto de santo onde realizava a ingestão do chá.

O ritual do santo daime era até então desconhecido de mãe Natalina. Somente alguns meses mais tarde ela visitou a igreja Céu de Maria ${ }^{13}$ e tomou contato com a doutrina daimista, além de obter também uma aproximação no astral ${ }^{14}$ com seus fundadores, Mestre Irineu e Padrinho Sebastião. Ela se fardou, ou seja, iniciou-se oficialmente na doutrina daimista algum tempo depois, quando realiza uma visita à igreja matriz da doutrina, o Céu do Mapiá, no município de Pauiní-AM realizando uma viagem desejada por um grande número de daimistas, sobretudo por residir nessa igreja grande parte da responsabilidade histórica pela difusão da doutrina do santo daime.

Ela frequentou os cultos daimistas por aproximadamente 10 anos até chegar o momento em que passou a utilizar o daime em seu terreiro, iniciando os rituais públicos de umbandaime. Madrinha Natalina não considera a entrada do daime em seu terreiro como uma decisão de sua responsabilidade, afirmando que o início do umbandaime foi realizado pelo Padrinho Sebastião junto ao Mestre Irineu através de uma ordem do astral.

O culto do umbandaime no terreiro da madrinha Natalina acontece há aproximadamente 5 anos. Atualmente ocorre uma vez por mês, aos domingos, alternando quinzenalmente com trabalhos da doutrina daimista como Cura, Concentração e festas para os santos, como São Miguel e Oxóssi. Todo ritual com daime possui um custo de 30 reais aos participantes, destinados aos custos de produção e transporte do chá.

Aos sábados, o terreiro oferece atendimentos de desobsessão ao público em geral, como parte de um dos compromissos da religião com a prática da caridade.

\footnotetext{
${ }^{13}$ Céu de Maria, fundada por Glauco Vilas-Boas, foi uma das primeiras igrejas do Santo daime de São Paulo e atualmente é a maior, em número de adeptos, fora do Acre.

${ }^{14}$ Astral, na categoria daimista, refere-se ao plano espiritual cujo acesso é facilitado pelo daime. É onde habitam os seres espirituais e os mestres fundadores da doutrina e representa um plano aberto à comunicação com o plano terreno.
} 
Nesses trabalhos, que figuram como os principais trabalhos de umbanda desenvolvidos pela mãe de santo, os consulentes recebem passes que visam afastar os espíritos obsessores. Essa prática ritual, herdada de seu irmão, é realizada por ela dentro da formatação umbandista desde seus 18 anos de idade.

O segundo terreiro que compõe o objeto dessa pesquisa é o Instituto Cultural Sete Porteiras do Brasil. O espaço foi fundado em 2009 por Jorge Scritori, que anteriormente realizava seus trabalhos em um terreiro próximo à estação de metrô Carandiru, também na zona norte da cidade. Jorge decidiu fundar seu próprio terreiro após uma ruptura com sua mãe, responsável pelo atendimento espiritual na umbanda realizado em seu próprio terreiro. $\mathrm{O}$ sacerdote pertence à terceira geração de uma família dedicada às práticas umbandistas, iniciada pelo pai de sua mãe, um imigrante italiano dedicado ao benzimento e que também foi definido por Jorge como um juremeiro tombado, o que, em outras palavras, significa que ele foi iniciado e possuía considerável conhecimento sobre o sistema religioso da Jurema. Estes atributos, entre outros fatores, possibilitaram sua projeção como liderança espiritual em seu próprio terreiro no sul do Paraná.

Segundo ele, a ruptura com sua mãe fez-se necessária em decorrência de uma crise de gerações, pois as necessidades das pessoas atualmente não correspondem mais às necessidades de 30/40 anos atrás. Essa desatualização constatada nos conhecimentos herdados inviabilizava sua realização prática, o que demandou uma correção do descompasso entre as demandas que deveriam ser supridas e o modo de fazê-lo.

Uma longa escadaria leva até o salão que possui uma grande área envidraçada, praticamente sem divisórias, apenas com um pequeno escritório ao fundo em um dos lados e, do lado oposto, os banheiros. No grande salão é comum acomodar-se entre 200 e 300 pessoas em dias de atendimento espiritual de entidades da umbanda. Nos outros rituais, sobretudo nos trabalhos de desenvolvimento do corpo mediúnico do terreiro, em que não ocorrem atendimentos espirituais ao público, existe uma frequência variável entre 80 e 100 pessoas.

Este foi o terreiro de umbanda que realizou os rituais com maior número de participantes durante a realização dessa pesquisa, tanto em número de médiuns como de frequentadores em geral. O corpo mediúnico da casa é composto por cerca de 70 médiuns, segundo o sacerdote do centro, porém o maior número de médiuns observados 
presentes em um trabalho exercendo essa função foram 35 , um número ainda assim expressivo.

A primeira experiência de Jorge Scritori com o daime foi em 2006, e seu relato enfatiza a mudança ocorrida em sua vida a partir de então. Nessa experiência inicial em um pequeno grupo, Jorge teve uma experiência que classificou como uma miração ${ }^{15}$ protagonizada por mestre Irineu sem saber, contudo, quem era mestre Irineu naquela ocasião.

Jorge não se $\operatorname{fardou}^{16}$ na doutrina do santo daime, mas encara sua vivência de alguns anos nos rituais do santo daime como um processo equivalente a uma iniciação, porém sem ter passado por um rito propriamente iniciático. No ano de 2010 introduziu o santo daime em seu terreiro atual, localizado no Bom Retiro, através da realização de alguns rituais esporádicos. Inicialmente os rituais com daime eram reservados ao corpo mediúnico e, quase sempre, eram realizados no formato de concentrações até que, após dois anos nesse formato, inicia-se uma aproximação ritual com a umbanda de forma mais consistente.

Essas giras com daime não ocorreram durante o período desta pesquisa, portanto, não terei muito a relatar sobre esse ritual. Durante o período de dois anos, tempo em que me dediquei ao acompanhamento do calendário ritual deste terreiro, apenas um ritual de Concentração foi realizado, relatado no diário de campo. Esse fato provavelmente reforça o caráter incipiente do encontro entre esses dois sistemas religiosos através do caso concreto protagonizado por este centro religioso. O pai-desanto Jorge Scritori teve seu primeiro contato com as giras que envolviam a ingestão de daime na igreja Reino do Sol.

O Reino do Sol se consolidou como igreja de forma praticamente simultânea ao seu estabelecimento no sítio São Francisco, o que ocorreu por volta do ano de 2002. Antes desse período, o Reino do Sol, que ainda não possuía esse nome, constituía-se enquanto um grupo de pessoas que não encontrava espaço nos ritos do santo daime para

\footnotetext{
${ }^{15}$ As mirações possuem em sua etimologia a raiz na palavra em espanhol mirar, ou seja, ver. Essas mirações quase sempre estão relacionadas ao plano astral, mas podem também remeter à memória do adepto ou às visões de formas abstratas.

${ }^{16}$ Fardamento é o nome dado na doutrina daimista ao processo iniciático. A farda é o nome dado à roupa ritual e se divide em dois tipos: azul, para os trabalhos considerados mais ordinários como Concentrações e Cura, e branca, utilizada para os trabalhos considerados de caráter mais festivos como os bailados e as festas dos santos.
} 
manifestação da mediunidade, o que os levou a realizarem reuniões próprias no salão cedido pela igreja do santo daime chamada Céu da Nova Era, situada em São Lourenço da Serra, para praticar esse "estudo".

Estava à frente desse grupo Antônio Alves Marques Júnior, ou Gê Marques, como é conhecido, que se definiu como um membro do santo daime que via a necessidade de tratar a incorporação em outros moldes, que o modelo daimista não permitia realizar. Tem início então o desenvolvimento das "giras" com daime, por volta do ano 2000, no espaço cedido pela igreja do santo daime Céu da Nova Era. Esses trabalhos iniciais com a umbanda realizados pelo grupo ocorriam sem a pretensão de se formar uma igreja ou sequer seguir o calendário ritual do CEFLURIS.

Gê Marques inicia então esse processo a partir de uma instrução recebida, que apontava para a necessidade de se desenvolver as giras durante 7 ciclos, sendo cada ciclo composto por 7 giras, totalizando 49 giras abertas. As giras fechadas, contendo estudos específicos quase sempre restritos ao corpo mediúnico do grupo, não eram contabilizadas. Essas giras desenvolveram-se ao longo de 7 anos e, durante esse período, o grupo cresceu e passou a ter o espaço físico para realização dos rituais como um fator limitador.

O sacerdote então recebe, por volta da quarta gira realizada, um hino chamado "Casa própria", que se tornou o hino oficial da igreja Reino do Sol. Esse hino enunciava a necessidade de uma casa própria para os caboclos trabalharem e, por capricho do destino, o grupo entra em contato com um médium, Pai Dalmo, citado mais adiante, que ajuda a articular a mudança dos trabalhos para um novo espaço que é atualmente onde se situa a igreja Reino do Sol.

O grupo obtém licença de funcionamento junto ao CEFLURIS e passa a introduzir o calendário ritual do santo daime em seus trabalhos paulatinamente, pois foi considerado impraticável cumprir o extenso calendário ritual daimista de imediato. No início foram realizados poucos trabalhos da doutrinada daimista, que eram realizados sempre de forma alternada com as giras, com destaque para as Concentrações nos dias 15 e 30. Eram realizados também alguns bailados considerados "mais oficiais" e alguns trabalhos de São Miguel que, como as giras, também eram trabalhos de "banca aberta" e proporcionavam o estudo da mediunidade.

O pequeno grupo que havia iniciado a prática das giras com daime cresceu até 
atingir, na última das 49 giras realizadas, o quórum de 350 pessoas, no ritual caracterizado como "encerramento de obrigação". Atualmente o número de adeptos com vínculo institucional está em torno de 300 pessoas, segundo Gê Marques. Durante o acompanhamento dos rituais constatou-se, em algumas giras com daime, a participação de 170 pessoas, o que caracteriza esse grupo como realizador dos rituais com daime que mobilizam o maior número de participantes dentre os centros religiosos estudados.

De acordo com a liderança espiritual do centro é notável, na composição do grupo, a presença de artistas, músicos, cantores, estudantes universitários, acadêmicos e intelectuais. O próprio Gê Marques possui um histórico acadêmico na Universidade de São Paulo, com graduação pela Escola de Comunicação e Artes e uma passagem pelos cursos de Ciências Sociais e Filosofia, sem concluí-los. Recentemente produziu uma dissertação de mestrado em Ciências da Religião pela Pontifícia Universidade Católica/SP, que inclusive faz parte da bibliografia analisada nesta pesquisa.

A aproximação que desenvolvi em relação ao Reino do Sol me levou, através das encruzilhadas dos caminhos, ao conhecimento de mais um terreiro, o Templo de Umbanda São Benedito $^{17}$, pertencente a Jamil Rachid, ou pai Jamil de Omolú, como também é conhecido. O grupo de Gê Marques possui grande proximidade com este terreiro, ao ponto de possuir a concessão do espaço para realizar trabalhos de “atendimento mediúnico sem daime" semanalmente, desde o ano de 2011.

Para compreendermos as circunstâncias que levaram o grupo daimista a realizar trabalhos no espaço do Templo São Benedito é necessário entender um pouco a trajetória do responsável por essa conexão, José Dalmo Ribeiro Ribas, ou pai Dalmo, como é conhecido. Trata-se de um babalorixá, filho-de-santo de pai Jamil, que realiza “atendimentos coletivos" no Templo de Umbanda São Benedito desde 1992, e que

\footnotetext{
${ }^{17}$ O Templo de Umbanda São Benedito é atualmente o terreiro de umbanda mais antigo da cidade de São Paulo em funcionamento, segundo Gê Marques. Sua fundação remonta ao ano de 1955, dois anos antes de Pai Jamil Rachid, o sacerdote responsável, tornar-se presidente da federação "União de Tendas de Umbanda e Candomblé do Brasil", em 1957, cuja sede é o próprio terreiro. Pai Jamil foi o responsável pela organização da festa de São Jorge por 50 anos, um dos eventos de maior visibilidade das religiões afro-brasileiras na cidade de São Paulo e que é resultado de uma promessa feita ao santo pelo sacerdote. Entre outras realizações, no plano institucional, ele contribuiu para a expansão da umbanda fora do país, participando ativamente da fundação de sedes umbandistas na Argentina, Uruguai, Paraguai e Portugal. Atualmente realiza giras de umbanda com frequência mensal em seu terreiro, sempre na primeira sextafeira do mês, porém devido a problemas de saúde nem sempre pode acompanhar pessoalmente os rituais.
} 
acontecem atualmente às sextas-feiras no período da manhã.

Sua iniciação na umbanda data de meados dos anos 60, no terreiro de Mãe Clara, localizado na região do M’boi-mirim. Segundo Dalmo, sua primeira visita ao terreiro resultou no que é descrito como sua primeira experiência de incorporação. Após alguns anos, seu caboclo lhe pediu para "montar uma casa". Pouco tempo depois, um grupo de médiuns resolve abrir um novo terreiro, visto que Mãe Clara havia realizado sua passagem ${ }^{18}$ e com isso seus filhos e filhas de santo procuravam um novo lugar para prosseguir com os trabalhos da umbanda.

É fundado então o Templo de Umbanda Sete Ondinas, em Pirituba, cuja função de pai-pequeno havia sido designada à Dalmo. Após uma nova divisão desse grupo, o caboclo de Dalmo apresenta novamente um pedido, dessa vez para que se torna um babalorixá de seu próprio terreiro. Pai Dalmo muda-se então para o Jardim Arpoador, por volta de 1984, e exerce a função de babalorixá em seu terreiro por 4 anos, até mudar-se novamente para a Rua Cristiano Viana, em Pinheiros, próximo ao terreiro do Pai Jamil.

Seu terreiro em Pinheiros situava-se em um imóvel que possuía dupla função, abrigando também seu consultório de terapia onde realizava consultas como psicólogo, área de sua formação acadêmica. Neste local ele exerceu atividades como liderança espiritual por aproximadamente 3 anos, até seu fechamento. Foi nesse momento que pai Dalmo recebeu o convite de Pai Jamil para realizar atendimentos no Templo de Umbanda São Benedito às sextas-feiras, atividade que realiza até o momento.

Pai Dalmo tomou "ayahuasca" pela primeira vez por volta de 1973, na união do vegetal, naquela que seria, segundo o sacerdote, a primeira igreja da UDV ${ }^{19}$ em São Paulo denominada Princesa Irunaiá. Pai Dalmo relata uma experiência profunda extraída desse primeiro encontro com o chá, que só voltaria a ocorrer após um intervalo de dez anos, na primeira igreja do santo daime de São Paulo chamada Flor Das Águas.

Em meados de 2002, Pai Dalmo relatou sua participação em uma cerimônia de ayahuasca com um xamã peruano chamado Vitor Nieto. Ele considera essa experiência como extraordinária e, em uma tentativa de tradução do contato com o inefável

\footnotetext{
${ }^{18}$ Termo utilizado entre adeptos do santo daime para referir-se ao processo de transição para outro plano desencadeado pela morte.

${ }^{19}$ A união do vegetal constitui uma das 3 matrizes das chamadas religiões ayahuasqueiras.
} 
proporcionado pela "catarse", define o ocorrido como "o céu se abrindo sobre sua cabeça".

Essa experiência teve também outras implicações na trajetória religiosa de pai Dalmo, pois é nesse ritual que ocorre o encontro com uma frequentadora do então incipiente grupo de práticas umbandistas de Gê Marques, que até então não possuía um nome. Surge então o convite a Dalmo para que ele conheça essa aproximação ritual da umbanda com o santo daime.

O envolvimento com o grupo é imediato e, no mês de setembro do mesmo ano, pai Dalmo participa do primeiro trabalho no local onde atualmente está situada a igreja do Reino do Sol, em Parelheiros. Pouco tempo depois começa a realizar um trabalho que envolve beber daime e a realização de práticas umbandistas na igreja.

Com o Reino do Sol já consolidado enquanto igreja do santo daime, ocorreu a necessidade da formatação de um trabalho de atendimento de umbanda. Necessidade suprida por um terreiro na confluência da Rua Rodésia com a Rua Harmonia, chamado Escola da Rainha.

Esse terreiro funcionou por 4 anos, mas a pressão exercida pelos vizinhos e pela prefeitura levou ao seu fechamento. Seguiu-se então um período de um ano sem a realização desse acolhimento, tido como equivalente a uma gira de umbanda, até que surge a possibilidade da utilização do espaço do Templo de Umbanda São Benedito, através da articulação feita pelo pai Dalmo que já realizava atendimentos como práticas umbandistas nesse local.

A utilização desse espaço pelo grupo do santo daime iniciou-se em 2011, e desde então o trabalho que vem sendo desenvolvido é definido como um atendimento mediúnico sem daime, mas com o modo de trabalhar do daime. A atividade realizada é classificada pelo grupo como um acolhimento em que as entidades espirituais conversam, aconselham e realizam passes mágicos nos consulentes. $\mathrm{O}$ atendimento realizado é visto pelo grupo como uma forma de desenvolvimento mediúnico, sendo realizado por médiuns que já possuem uma trajetória espiritual que os habilitam a realizarem as consultas. É um desenvolvimento mediúnico através das práticas umbandista, sem daime, realizado por um grupo daimista que significa a umbanda a partir do santo daime e, ao mesmo passo, transforma as práticas daimistas através de uma leitura da umbanda. 


\section{Metodologia no estudo de rituais com ayahuasca}

Foram realizadas 20 entrevistas, com os sacerdotes responsáveis e com frequentadores dos rituais que articulam santo daime e umbanda em 3 centros religiosos: Sete Pedreiras; Sete Porteiras e Reino do Sol - não foram realizadas entrevistas com os frequentadores dos rituais realizados pelo pai Jamil pois os mesmos não participam de rituais que dialogam com o santo daime. O plano de campo consistiu na gravação das entrevistas, que foram transcritas, e também a produção de registro audiovisual dos ritos públicos dos três terreiros e da igreja de santo daime.

Encontrei nestes locais de culto desde rituais bastante consolidados, como as giras do Reino do Sol, até uma única experiência com o santo daime em 2011 no terreiro 7 Porteiras, que desde então não voltou a se repetir, porém, com a possibilidade de ocorrer a qualquer momento de acordo com o sacerdote responsável, o que demonstra, entre outras coisas, o caráter incipiente do diálogo entre as duas religiões.

Constatei também que o interesse pela umbanda desenvolvido pelo grupo da igreja Reino do Sol vai muito além dos estudos realizados em suas giras. O grupo estende suas práticas para um dos mais antigos terreiros de umbanda da cidade de São Paulo, dirigido pelo Pai Jamil Rachid, localizado em Pinheiros.

Diferentes formas e níveis de aproximação vem sendo realizados dada a porosidade das duas manifestações religiosas que compõem o objeto de estudo. $\mathrm{O}$ interesse em investigar essas possibilidades de interação se deve ao fato de todas elas serem experiências recentes e, ao mesmo tempo, materializarem uma nova face de um diálogo que já ocorrera de outras formas e em outras ocasiões no decorrer da história desses sistemas religiosos.

Iniciei a observação dos rituais relatando a experiência em um diário de campo, onde as anotações eram realizadas após o ritual. Essa metodologia, conforme constatei, não apresentou um grande rendimento de informações nos primeiros rituais e, a partir dessa constatação, optei por fazer as anotações durante o próprio ritual. Esse diário me permitiu construir um quadro esquemático que pudesse dar conta dos ritos observados e ajudar na análise das categorias envolvidas nesse trânsito entre as duas religiões.

Adoto nesse trabalho uma abordagem conceitual do daime, enquanto bebida sacramental, a partir do próprio conceito nativo que o classifica como um ser divino transformado em líquido. Não optei pelos termos “droga" ou "alucinógeno" por estarem 
carregados de preconceitos e terem seu sentido completamente divergente da visão nativa (Labate, 2004).

Existe, porém uma definição já proposta por Labate (2004, p. 33) que sustenta a bebida ritual como um enteógeno, através da argumentação realizada por MacRae (1992, p.16) que embasa a definição na etimologia do termo cuja raiz advém do grego antigo entheos, que significa "Deus dentro"; o neologismo significaria algo como "o que carrega deus dentro de si”. Essa definição torna-se relevante por levar em conta o caráter divino da bebida o que, em certa medida, aproxima-se da percepção nativa do chá. Talvez o maior ganho analítico obtido com essa definição reside na contraposição a categorias problemáticas do senso comum, ainda que resulte em outras implicações.

Ao buscar na etimologia uma justifica para utilização de uma categoria analítica, afasta-se da concepção nativa dos adeptos das religiões ayahuasqueiras, sobretudo do santo daime, que definem em muitos casos a bebida como um ser divino e não como um receptáculo do divino. Pode-se afirmar que a definição nativa do daime informa que o chá possui agência e é ele mesmo um ser divino, diferentemente de algo que carregaria o divino dentro de si.

Dessa forma, opta-se pela utilização da concepção nativa do chá como um ser divino, pois tal nuance faz-se crucial para o desenvolvimento do trabalho antropológico através de seus inúmeros desdobramentos na percepção de mundo adotada pelo grupo. Existe um divisor de águas analítico quando se busca o encadeamento de ações provocadas por algo que é dotado de agência própria, no caso um ser, capaz de ações e interações e, talvez aqui encontremos realmente a pedra de toque da questão, animado por uma força divina.

Mercante (2012) se aproxima dessa concepção quando diz que na ayahuasca, ou daime, "espírito e matéria se tornam unos e se influenciam mutuamente". O autor argumenta em outra passagem que o daime cruzaria as fronteiras entre físico e espiritual e por se tratar de uma substância espiritual transformada em física o chá atuaria nos dois níveis, fazendo com que uma aparente dualidade entre espírito e matéria desaparecesse.

Essa definição é a que melhor trabalha a ideia do chá como possuidor de um princípio mediador, porém no plano analítico se afasta do que considero ser a principal atribuição da bebida, que seria, em suma, a capacidade de transmitir seu caráter divino ao corpo do participante ao qual adentra. Essa característica deve-se ao fato da 
ayahuasca ser detentora de uma dualidade intrínseca que ao possuir outro ser, no caso o próprio participante do ritual, transfere através de uma relação de continuidade, o princípio do duplo pertencimento, permitindo assim o trânsito entre dois mundos a quem dela comunga.

De acordo com muitas entrevistas formais e informais que foram realizadas ao longo dessa pesquisa, a ayahuasca possui um papel fundamental na intensificação da experiência religiosa ${ }^{20}$. Essa definição nativa da bebida encontrada no campo das religiões ayahuasqueiras, seja nas igrejas ou nos terreiros, é apontada por madrinha Natalina:

ALVARO: O que é o Santo daime para você?

NATALINA: É como diz aquele hino: "É um ser divino". É o Santo daime para mim. Eu acho que para todos que tomam né.

Essa concepção da bebida, sobretudo a agência contida na ideia de sua força intrínseca, a coloca como um dos pilares centrais das doutrinas ayahuasqueiras, conforme se torna perceptível também no relato de Gê Marques:

ALVARO: O que é o Santo daime para você?

GÊ MARQUES: Primeiro, o santo daime é a bebida. Não estou querendo dizer com isso que nós chamamos a bebida de daime. Estou querendo dizer que é central nas nossas concepções e nas nossas experiências a ideia da força e da miração. Que são as manifestações do estado alterado de consciência por aquilo que chamamos de enteógeno. Não preciso discorrer sobre o significado de enteógeno para nós, o que ele representa, que isso você sabe. Agora, a bebida é central. A alteração da consciência permite um insight, um mergulho interno, o vôo xamânico e a experiência da catarse que às vezes é a da incorporação.

O que é notável é o fato do conceito de enteógeno ter se tornado também uma categoria nativa. A "alteração da consciência" como algo concomitante à participação nos rituais que envolvam a ingestão da ayahuasca colocam novos horizontes na discussão metodológica do fazer antropológico.

Pelo fato do antropólogo ser iniciado na maioria dos casos como ogã ou

${ }^{20}$ A intensificação da experiência religiosa proporcionada pelo chá é uma espécie de "lugar comum" no discurso nativo, como pude verificar através de uma série de entrevistas desenvolvidas desde 2009. 
equede, como se constata nas etnografias sobre o candomblé, que não prescrevem a necessidade do transe, a crença do antropólogo dificilmente é colocada à prova. (Silva, 2006). Quando se estuda uma religião que envolve a ingestão de um enteógeno, que necessariamente envolve o transe, o problema se desloca de sua crença ser questionada pelo grupo pesquisado, para questionar o limiar entre transe e crença que é agora internalizado no antropólogo.

Labate (2004) e Mercante (2012) se identificam como membros do grupo estudado, como fardados, o que não representa um problema do ponto de vista metodológico, apenas uma abordagem que oferece um leque de possibilidades e exclui outras. A questão que coloco é se o compartilhamento de um sistema de crenças compromete a realização de uma antropologia crítica. De acordo com Silva (2006, p.112):

\begin{abstract}
A clássica dicotomia entre crença e ciência, ainda que existente, já não exige do pesquisador posicionamentos tão excludentes entre si, principalmente após a crise dos grandes paradigmas materialistas e racionalistas que predominavam, sobretudo nas abordagens em ciências humanas de influência marxista dos anos 60 .
\end{abstract}

A seu modo, o antropólogo "nativo" mobiliza de determinada forma o arcabouço simbólico do grupo, pois se presume que para ser nativo ele compartilhe determinados símbolos do grupo ao qual pertence, demonstrando algum grau de afinidade. Quando esse posicionamento é apontado e discutido nos trabalhos antropológicos, o resultado tende a ser um esclarecimento honesto para o leitor a respeito do lugar de onde se fala.

A discussão das implicações do envolvimento religioso do pesquisador passa a assumir um lugar privilegiado nos trabalhos recentes de antropólogos que estudam as religiões ayahuasqueiras. O que não necessariamente se observou no estudo das religiões afro-brasileiras.

[...] mesmo para os antropólogos que se permitem experiências subjetivas mais intensas com o universo pesquisado, as consequências desse envolvimento não são relatadas de forma sistemática ou incorporadas também como um objeto de reflexão nas etnografias que elaboram. (Silva, 2006, p.112)

Primeiramente não se trata de ser iniciado ou não. A iniciação religiosa do 
antropólogo em religiões afro-brasileiras não implicará necessariamente na experiência do transe religioso. $\mathrm{O}$ que podemos afirmar a respeito da iniciação é que ela abrirá novas redes de acesso no terreiro e permitirá a observação do que é velado ao público não iniciado.

Essa inserção no campo representaria um envolvimento em determinado grau, dada a proximidade e o estabelecimento de relações de confiança com os adeptos. Essas relações terão influência decisiva no rumo da pesquisa, uma vez que ao optar por acessar determinadas redes de relações, outras serão suprimidas, como aponta Mercante (2012).

\begin{abstract}
Após dez meses comecei a ver um universo completamente diferente descortinando-se diante meus olhos. Estava apenas começando a me tornar consciente da complexidade dos símbolos, ensinamentos, significados e seres da Barquinha. Ao mesmo tempo, outro grupo de questões estava emergindo: se não tivesse me fardado, se eu tivesse apenas "olhado pelo lado de fora", será que seria capaz de perceber esta complexidade? Ao final do trabalho de campo as pessoas estavam confiando mais em mim, e não era mais somente o pesquisador, era o irmão também. $\mathrm{O}$ quanto as pessoas teriam falado comigo se não tivesse me fardado? (Mercante, 2012 p. 60).
\end{abstract}

Um dos dilemas que enfrentei em meu trabalho de campo não dizia respeito à iniciação, em um primeiro momento. Eu não me considero um adepto da umbanda e, mesmo após ter frequentado terreiros por aproximadamente um ano e ter recebido um convite para me iniciar, não tive interesse em me integrar ao corpo de médiuns de nenhum terreiro.

Ao encarar essa discussão do ponto de vista da inserção no campo, posso dizer que a iniciação, no sentido de rito iniciático, não é algo muito claro no umbandaime. Os dois terreiros e a igreja de santo daime onde realizei minha pesquisa não possuem um rito iniciático formatado para esse ritual. O fato de não haver esse rito específico, as fronteiras do pertencimento de um adepto ao culto são difusas.

Levando em conta minha inserção no campo, o estabelecimento de relações desde minha primeira pesquisa enquanto aluno da graduação e minha frequência nos rituais de umbandaime posso afirmar que o fato de eu não ser um "adepto" não ofereceu limitações no acesso a pessoas e a informações.

Madrinha Natalina me classifica inclusive como um "corredor de gira", termo nativo para médiuns que transitam entre terreiros. O que nem sempre é bem visto nos 
terreiros de umbanda, mas é relevado dado meu interesse pela pesquisa antropológica.

Nas pesquisas antropológicas desenvolvidas antes dos anos 1940, especialmente no campo das religiões afro-brasileiras, o tratamento reflexivo dado à iniciação do pesquisador na religião estudada era praticamente inexistente. Isto se deve em parte à discriminação que essas religiões sofriam no espaço público e que acabavam coibindo o pesquisador a desenvolver discussões detalhadas a respeito (Silva, 2006).

Roger Bastide leva a novas fronteiras, no que diz respeito à empatia, a observação participante proposta por Malinowski. Sua viagem à Bahia descrita em Imagens do Nordeste Místico em Branco e Preto (1945) levou-o a defender uma metodologia em que o pesquisador se colocaria não mais do "lado de fora" da experiência, mas “dentro", tratando-a como se fosse sua (Silva, 2006).

Outra forma de inserção no campo foi experimentada por Pierre Verger que, sem se preocupar na realização de um diálogo teórico-acadêmico, realizou importantes trabalhos de pesquisa com um apurado nível de detalhamento. A realização das etnografias estava em um plano um pouco mais afastado que sua experimentação religiosa que, em parte, contribuiu com o acesso a informações e práticas veladas ao público não iniciado (Silva, 2006).

Depois dessas duas possibilidades de abordagem no campo das religiões afrobrasileiras, os anos 70 foram marcados por uma geração de antropólogos em que "tornar-se nativo" irrompe como palavra de ordem. Evidenciava-se no debate a existência de uma fronteira difusa entre a observação e a "comunhão" que, de certa forma, era amparado pelo contexto de visibilidade e aceitação conquistado pelas religiões afro-brasileiras (Silva, 2006).

De acordo com Silva (2006) a posição ambígua do antropólogo em relação à sua crença e à sua presença na religião é em parte devedora de não existir a exigência de uma conversão internalizada nas religiões afro-brasileiras que também não se impõem como exclusividade de opção religiosa.

Minha maior inquietação com relação ao trabalho de campo foi a viabilidade de realizar observações profícuas sob o efeito da ayahuasca. À princípio havia planejado realizar algumas observações ingerindo a bebida e outras sem ingeri-la. Coloco a questão dessa forma, pois não me foi autorizado participar de rituais sem tomar o chá, conforme relato no caderno de campo. 
Notei que havia um pressuposto óbvio nos grupos ayahuasqueiros que frequentei de que todos os participantes do ritual devem ingerir o chá, afinal como alguém quer participar de um ritual cujo pilar central é a bebida e não ingeri-la? Nesse caso caímos em uma situação onde participação do ritual e "daime" são coisas inseparáveis.

Notei isso no início da pesquisa e percebi que caso insistisse em não tomar o chá geraria atritos desnecessários para uma pesquisa que estava apenas se iniciando. $\mathrm{O}$ campo me impôs uma forma de abordagem que me fez muitas vezes duvidar de minha capacidade de realizar uma etnografia sob essas condições.

$\mathrm{Eu}$ arriscaria dizer que foi essa minha iniciação, visto que não existe um rito iniciático formatado pelo grupo e, de acordo com a concepção nativa, a iniciação está ligada a um controle da "mediunidade". Trata-se de um aprendizado, a realização de uma etnografia nessas condições não é nada óbvia. O que em um primeiro momento me pareceu uma experiência caótica e desestabilizadora foi tomando contornos sólidos ao longo da pesquisa, através do desenvolvimento de um autocontrole.

A questão em si não era acompanhar os rituais e depois etnografa-los em casa, como ocorre em grande parte das etnografias nesse campo. Descartei a ideia de gravar os rituais pois, se estava ali no momento em que as coisas aconteciam, porque tomar notas depois? Isso sem mencionar os dados que seriam perdidos, pois não conseguiria concatenar posteriormente o que foi visto, o que foi falado e quais foram minhas impressões no momento.

Como disse anteriormente, isso não foi algo simples. É sensível a melhora obtida na qualidade de minhas anotações de campo no decorrer da pesquisa. Isso em parte decorre de uma maior familiaridade com os rituais e as pessoas. A escrita durante o ritual passa a provocar um constrangimento menor em mim mesmo, pois sempre considerei as anotações durante os rituais como algo perturbador da dinâmica cerimonial.

O que ocorre é que dada a grande pluralidade de manifestações encontradas nestes cultos religiosos, que vão desde incorporações simultâneas de um grande número de pessoas a golpes de artes marciais executados individualmente, minha participação enquanto etnógrafo é aparentemente aceita ou, ao menos, a não aceitação, se existiu, não se fez de forma aparente. Houve inclusive a tentativa por parte de um rapaz em me 
classificar como "aquele que estava psicografando o ritual", antes mesmo que pudesse explicar meus reais objetivos. O conceito de psicografia é oriundo do universo kardecista e remete basicamente a uma prática de comunicação com espíritos de mortos que se manifestam escrevendo textos com mensagens bastante variadas através dos médiuns.

Essa classificação realizada pelo participante do ritual remete ao questionamento sobre a autoria do próprio texto etnográfico que, em última instância, produziu-se através de um orquestramento de forças que se manifestam durante o ritual e, dessa forma, nada impede que espíritos de antropólogos mortos tenham enviados insights que ficaram registrados em minhas páginas de forma quase sempre bastante ilegível.

A transformação da caligrafia durante a realização das notas de campo talvez corrobore para classificação feita pelo rapaz. Muitas vezes a letra contorcida se misturava à folha molhada pelas lágrimas de quem se esforçava para traduzir em palavras experiências arrebatadoras no momento em que elas ocorriam. É possível, inclusive, através da análise da caligrafia dos cadernos de campo identificar os momentos do ritual em que essas experiências eram mais intensas e, ao mesmo tempo, a natureza das anotações que elas produziam.

Minha relação com o caderno de campo e com a própria escrita etnográfica foi se transformando ao longo do campo. Sentia-me cada vez mais à vontade para escrever, seja "bailando" ou de joelhos, obviamente nesses casos eu tomava apenas pequenas notas. Era minha forma de apropriação do ritual ou, pelo menos, foi essa percepção que desenvolvi sobre o modo como as pessoas encararam minhas atividades de pesquisa.

$\mathrm{Na}$ Boca da Mata surge como título dessa dissertação por uma série de motivos que foram revelando-se ao longo da pesquisa. Primeiramente, da perspectiva do santo daime, a boca da mata remete a localização das populações caboclas responsáveis pela formação do sistema religioso em questão e ao mesmo tempo integrantes dos principais polos irradiadores da doutrina daimista que, atualmente, são objeto de peregrinação de inúmeros frequentadores e adeptos dessa e de outras religiões ayahuasqueiras.

Trata-se aqui de um meio físico, uma fronteira entre o local onde se estabelece a comunidade e a floresta que a circunda. A boca da mata não é a mata, mas o limiar entre o território seguro, conhecido e habitável e a floresta, morada de outros seres, do 
imponderável e de uma série de perigos. A Boca da Mata é a passagem entre um regime e outro e pressupõe, justamente, uma zona de sobreposição que não é a comunidade tampouco a floresta, mas que se realiza como as duas coisas ao mesmo tempo sendo, portanto, uma região de transformação de um espaço em outro.

As comunidades caboclas que habitam essa região fronteiriça e, portanto, detêm o conhecimento necessário para transpor esse limiar físico e cósmico que permite adentrar a outro regime de forças possuem, elas mesmas, a habilidade de realizar travessias ontológicas acessando diferentes concepções do ser em suas relações com outras populações, sobretudo populações indígenas e comunidades religiosas afrobrasileiras, fazendo dessas relações constantes travessias e cada travessia uma transformação por definição.

Tomando-se a Boca da Mata de uma perspectiva das religiões afro-brasileiras, sobretudo a umbanda, o que se nota é a atribuição dessa região a um lugar específico do mundo astral. O lugar onde moram os caboclos da religião que, nesse caso, trata-se de espíritos de índios. Nota-se que nesse caso os espíritos habitam a própria zona transição entre a aldeia do astral e a própria floresta mítica como se a natureza dos caboclos fosse justamente esse liminar, esse não pertencimento a aldeia tampouco à floresta, mas contendo-as simultaneamente e se realizando justamente como transformação de uma coisa na outra.

A Boca da Mata vista a partir do santo daime sugere que a boca é justamente por onde a bebida da mata penetra e que, ao passar esse liminar do corpo, se transforma, deixando de ser bebida e operando ao mesmo tempo uma transformação ontológica do corpo que a recebe. Esse mesmo corpo agora representa a transformação que permite com que ele circule pelo mundo astral e pelo mundo terreno, sendo esse corpo agora o próprio liminar desses mundos, não pertence mais ao mundo terreno nem ao mundo astral, mas se realiza das duas formas simultaneamente.

O interesse dessas populações caboclas amazônicas pelo caboclo umbandista pode ser entendido justamente como a busca de um princípio cosmológico transformador que possibilitasse o encontro do santo daime com a umbanda. Os caboclos do santo daime buscaram no caboclo da umbanda o conhecimento para realizar essa nova travessia, mas também a população urbana das grandes cidades continua seguindo por um caminho muito similar. Pretende-se demonstrar no decorrer deste 
trabalho que a travessia realizada por uma religião amazônica que agora encontra-se nas grandes cidades do Brasil, também é fruto de travessias de natureza cosmológica que produziram e ao mesmo tempo é produto desse diálogo entre os dois sistemas religiosos. 


\title{
Capítulo I - O espaço e as práticas rituais
}

\section{Quando a estrela vira o congá, ou o congá vira a estrela: uma análise do espaço ritual}

Os locais onde realizei a observação de ritos para a realização desta pesquisa são muito diferentes entre si. Não digo isso apenas para ressaltar as especificidades de cada local de culto, o que já é consagrado na bibliografia das religiões afro-brasileiras.

Trata-se de terreiros de umbanda, cujos sacerdotes possuem uma formação religiosa umbandista estabelecida durante um período de tempo variado e que, em determinado momento, estabelecem de diferentes formas o diálogo com o sistema religioso do santo daime.

No caso do Reino do Sol, o espaço ritual onde o grupo se constituiu não consistia em um terreiro, no sentido mais corriqueiro do termo. Mas sugiro que essa classificação possa ser aplicada aqui, considerando o papel central que as giras de umbanda com daime ocupavam nas práticas rituais do grupo.

\begin{abstract}
ALVARO: Você fundou uma igreja respeitando o calendário do santo daime. Como se deu a inclusão das giras no calendário?

GÊ MARQUES: Eu quase diria que foi a inclusão do calendário na gira. Porque nós nos satisfazíamos em ter esse trabalho diferenciado que era a gira e que ainda estava tomando formato, se adequando[...] porque me contentava em frequentar as igrejas nos seus outros calendários oficiais. Quando chegamos no espaço do Reino do Sol no entanto, verificamos que precisávamos do daime e resolvemos oficializar melhor a nossa existência.
\end{abstract}

O Reino do Sol atualmente é uma igreja de santo daime, cujo espaço ritual não possui um congá ${ }^{21}$ como nos terreiros, com seu peji $^{22}$ repleto de imagens de santos e entidades e os mais variados objetos rituais.

\footnotetext{
${ }^{21}$ Utiliza-se aqui a concepção nativa para o termo que faz menção ao espaço ritual que abriga o altar e outros elementos litúrgicos que variam muito entre um terreiro e outro. O congá é uma referência espacial nos terreiros. Os ritos de abertura realizam-se de frente para esse espaço assim como as saudações aos santos, esse ato denominado como "bater cabeça".

${ }^{22}$ Peji é o termo em yoruba utilizado para referir-se ao altar onde são colocadas as imagens dos santos e das entidades. São colocadas as imagens de santos católicos, orixás, entidades da umbanda e outros variados elementos litúrgicos como, por exemplo, velas e incensos.
} 
Quando as giras ocorrem, a mesa de centro ou estrela, como é chamada pelos adeptos, é deslocada para o canto do salão, funcionado como um congá, segundo Gê Marques. A estrela possui habitualmente fotografias do Padrinho Sebastião e de Mestre Irineu, ou alguma imagem deles, como ocorre no Reino do Sol, que junto com o Cruzeiro integram o repertório daimista. Santos católicos, flores, velas e incensos compõem o espaço sobre a mesa tradicional do santo daime.

No espaço ritual do terreiro Sete Pedreiras, a mudança que ocorre na realização das giras também envolve o elemento central da doutrina daimista, porém a estrela é trazida para o centro do espaço ritual. A estrela assume, dessa forma, um papel central no espaço ritual e na significação do umbandaime.

É possível notar uma relação entre a estrela e o espaço que ela ocupa. No centro do espaço ritual ela é estrela, na periferia ela é congá. No terreiro o umbandaime recebe a estrela. Na igreja de santo daime as giras recebem o congá. Isso é possível devido a semelhança estrutural entre os dois sistemas rituais, que permitem a comutação entre duas categorias mantendo-se a relação entre elas, independente do sistema religioso, seja no santo daime ou na umbanda.

O novo elemento que adentra o espaço ritual é o sistema simbólico com o qual será feito o diálogo durante o culto. Na igreja de santo daime a umbanda se faz presente no espaço com a transformação da estrela em congá e no terreiro, de forma análoga, realiza-se a mesma operação através da mesa em formato de estrela e dos objetos rituais daimistas depositados sobre ela.

A estrela está para o congá no santo daime, assim como o congá está para a estrela na umbanda. A relação entre a estrela e o congá mantêm-se, porém com termos alternados, seja no terreiro ou na igreja. Ocorre, nos dois casos, uma tradução entre dois sistemas que encontra nos dois modelos de gira diferentes formas de se pensar espacialmente os símbolos rituais. 


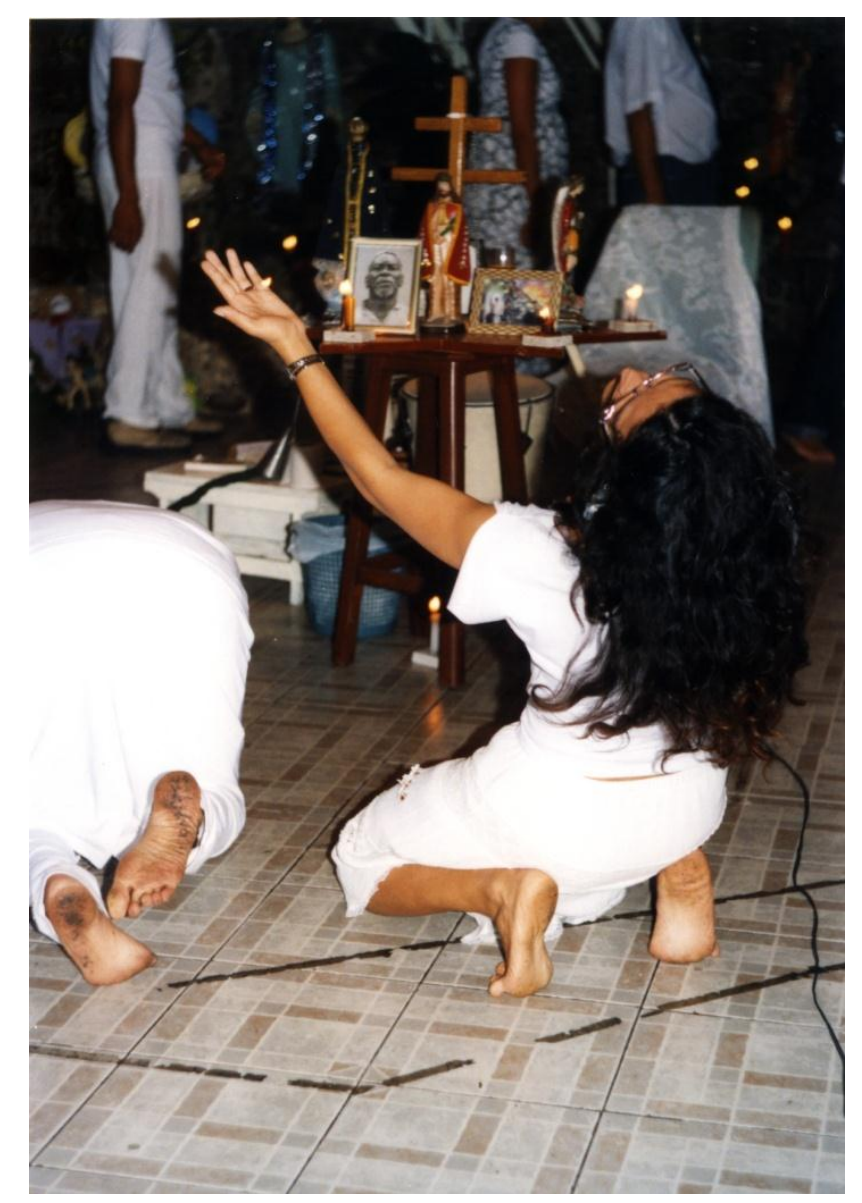

Figura 1 - Participante se ajoelha diante da estrela no terreiro 7 Pedreiras. Alvaro Russo, 2012. Sete Pedreiras

O modelo de apropriação do espaço ritual também pode ser dividido em duas formas, duas concepções de espaço que operam conceitos bastante reveladores da maneira como um sistema religioso se apropria do outro no diálogo entre santo daime e umbanda. Como será demonstrado a seguir, umas dessas formas é característica à igreja de santo daime e a outra ao terreiro de umbanda.

No terreiro, os rituais de umbandaime são realizados numa dinâmica de gira que possui movimento circular em sentido horário. A movimentação dos participantes, que pode se dar como ginga ou um simples caminhar, acompanha todo o ritual. Disso extraímos um formato circular de movimentação ao redor da estrela, posicionada no centro do salão.

A estrela representa o congá, o elemento espacial de referência central no umbandaime do Sete Pedreiras, portanto um elemento que representa a estrutura fixa no 
espaço, um parâmetro cuja centralidade confere certa rigidez à dinâmica ritual. É ao redor desse ponto de relativa fixidez que se dá a fluidez do ritual, através do movimento contínuo e das manifestações corporais das entidades.

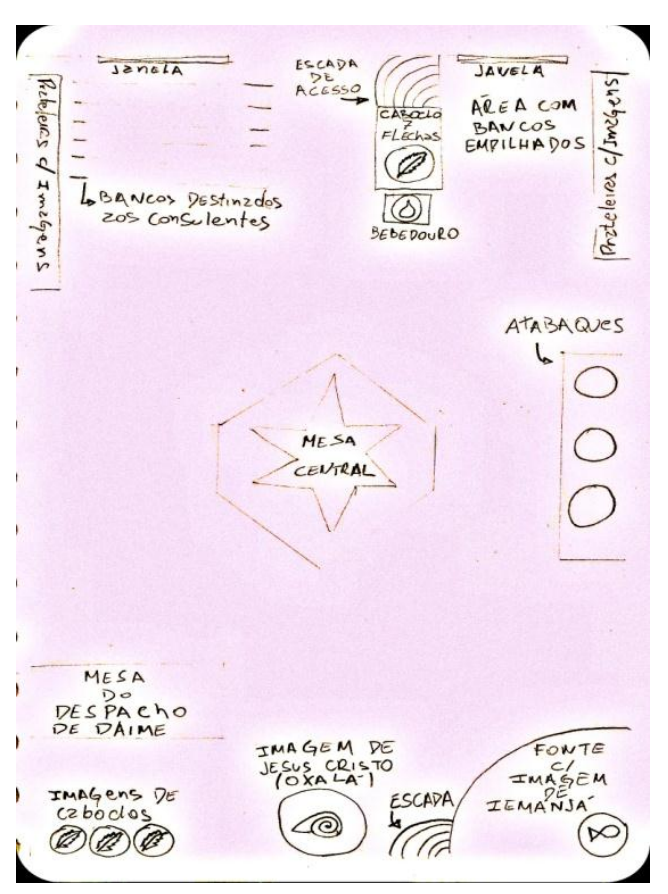

Figura 2 - Mapa do espaço ritual do terreiro Sete Pedreiras

O outro modelo espacial adotado é o que se manifesta no Reino do Sol. Com a estrela deslocada da posição central, as incorporações e os músicos passam a ocupar esse espaço. A estrutura da estrela de seis pontas permanece, na disposição espacial dos participantes, através do formato hexagonal. 


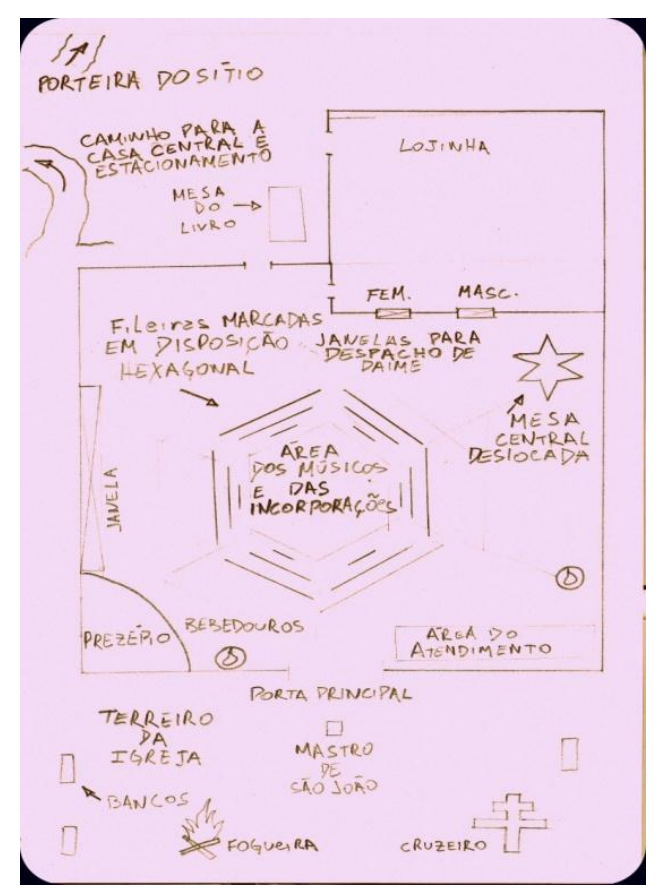

Figura 3 - Mapa do espaço ritual da igreja Reino do Sol

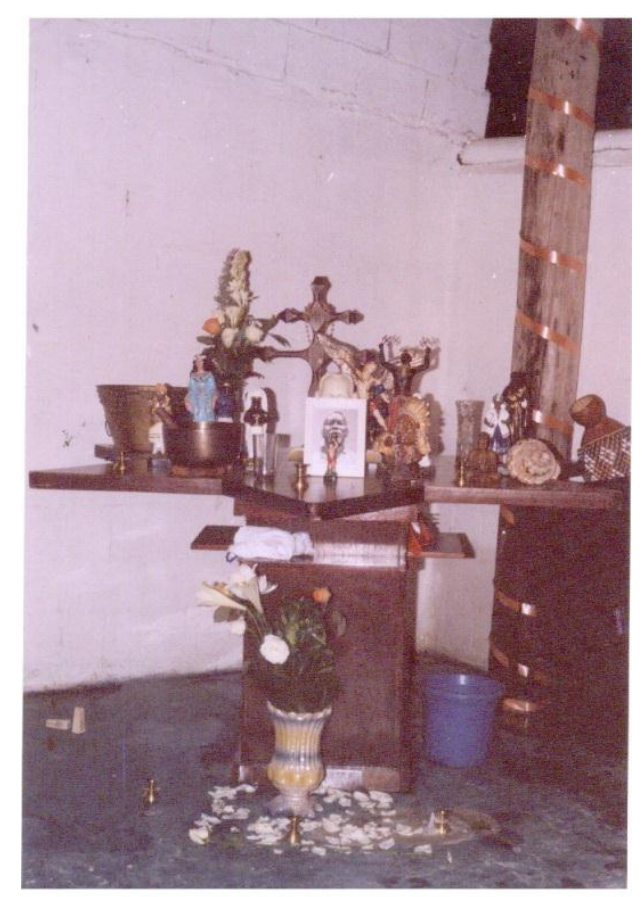

Figura 4 - Estrela do Reino do Sol colocada no canto do salão para a realização da gira. Alvaro Russo, 2013. Reino do Sol 
Ocorre um trânsito espacial entre fixidez e movimento quando olhamos para o terreiro e para a igreja. No modelo espacial do terreiro, o umbandaime possui uma centralidade estruturante na estrela e a fluidez do movimento ao redor desse elemento.

$\mathrm{Na}$ igreja, o que observamos é a fluidez do movimento se manifestando no centro do espaço ritual. A estrela, enquanto elemento estruturante, oferece o parâmetro hexagonal na disposição dos participantes. Podemos dessa maneira abstrair um modelo cujo polo umbandista é caracterizado por uma solidez central e um entorno fluido e, por sua vez, o polo daimista apresenta uma fluidez central e um entorno sólido.

Nesse caso, a fluidez está sendo admitida como mais próxima do sistema umbandista e, a solidez, como possuidora de uma maior afinidade ao sistema religioso do santo daime. A afinidade do sistema daimista à ordem e à disciplina são mencionados de forma recorrente na bibliografia havendo, inclusive, a constatação de alguns termos militares em seu vocabulário ${ }^{23}$. A fluide $z$ do sistema umbandista estaria essencialmente ligada a maior amplitude dada ao movimento corporal, à ginga, à incorporação e ao deslocamento na gira.

A existência de uma oposição entre movimento/perfilamento e fluidez/solidez, na questão espacial, encontrou uma resolução harmônica nas diferentes formas adotadas tanto pelo terreiro quanto pela igreja. As combinações dos dois sistemas em espaços distintos ocorrem com lógicas que traduzem e relacionam o dualismo existente entre centro e entorno. Os dois modelos apresentam como elementos recorrentes o ordenamento daimista, com sua estrutura organizacional de um lado e, de outro, a fluidez do movimento umbandista, com a amplitude da manifestação corporal.

\section{O centro é livre}

O fio condutor da leitura espacial pelos dois sistemas, apesar de distintas em termos estruturais, permanece muito próximo em termos ontológicos. O que ocorre nos dois espaços é a incorporação do outro, se considerarmos incorporação no sentido de agregação de um elemento exógeno. Nesse sentido, o elemento do sistema exógeno,

\footnotetext{
23 Por exemplo: Perfilamento, Farda, Fardamento, Soldados da Rainha da Floresta, entre outros. O imaginário militar é presente na doutrina do Santo daime onde a ordem e a disciplina se manifestam através da estrutura do ritual.
} 
seja no terreiro ou na igreja, assume a centralidade do espaço ritual.

A saída da estrela para que no seu lugar ocorram as incorporações implica, na organização do espaço, que o elemento exógeno assume o centro da gira no Reino do Sol. Assumindo-se a perspectiva do terreiro verifica-se, em movimento análogo, que a estrela daimista assume a posição central no umbandaime de madrinha Natalina. Essa adequação do espaço em que o sistema exógeno assume a posição central demonstra muito mais que uma simples adequação estrutural entre os dois sistemas.

O que o espaço diz através da representação espacial central de um sistema religioso exógeno trata-se de uma postura ontológica de abertura em que os sistemas englobam, de forma análoga, muito mais que elementos aparentemente centrais do Outro, mas, ao invés disso, trata-se de uma abertura à própria transformação ontológica que o outro possibilita.

Colocar o exógeno no centro do espaço ritual ao mesmo tempo em que se evidencia uma abertura estrutural entre os dois sistemas também demonstra uma concepção do ser que engloba o outro não como mera agregação de atributos, mas como uma busca pela transformação que esse contato proporciona. Com isso os sistemas religiosos não buscam uma imitação mútua, não se pretende ser como o outro, mas, ao contrário, evidencia-se a necessidade do outro como força motriz para a produção de seu próprio conhecimento sobre o cosmo.

Centro livre, nesse sentido, implica uma concepção do ser no sistema religioso do santo daime. Essa concepção, presente na doutrina daimista e bastante enfatizada pelo CEFLURIS, sobretudo através dos ensinamentos de Padrinho Sebastião, é uma postura ontológica que transmite um refinamento metafísico a buscar justamente na prática religiosa a transformação e a produção de conhecimento no sistema religioso através da incorporação do elemento exógeno.

O que se buscou aqui foi justamente demostrar como esse princípio ontológico da religião daimista foi traduzido em termos espaciais pelos dois sistemas e, dessa forma, questionar até que ponto esse posicionamento ontológico também não estaria alinhado a visão de mundo umbandista, apesar de não ser enunciado da mesma forma como ocorre no sistema religioso do santo daime. 


\title{
Santo daime e umbanda para trabalhar ${ }^{24}$ - uma análise dos ritos
}

\author{
Senhora da Paz, Senhora da Paz \\ Senhora da Paz, vem ver \\ Os teus filhos sobre a terra \\ Os teus filhos sobre a terra
}
Todos são iguais, Todas são iguais
Todos são iguais ao Pai
Quem trabalha é ema estrela
Verde, Azul e branca
Firmada no Astral
Reinado do Sol venha nos curar
Santo Daime e Umbanda para trabalhar
Jagube, Rainha, Homem, Fogo, Água
Sol, Lua, Estrela para se firmar

(Senhora da Paz, Sérgio Correa)

No umbandaime, além da utilização dos elementos litúrgicos recorrentes aos rituais de umbanda, apesar das idiossincrasias que os diferenciam, alguns elementos do santo daime adentram ao espaço ritual coexistindo e integrando-se ao já vasto inventário de objetos existente. Tal coexistência se faz possível por uma relação dupla de sentido em que os elementos litúrgicos umbandistas são lidos à luz da cosmologia daimista e os elementos característicos ao culto do santo daime encontram espaço simbólico no terreiro com o compartilhamento de alguns significados, mas também com a criação de novos dentro da cosmologia do umbandaime.

Um exemplo nessa direção são as ervas utilizadas na defumação, bastante utilizadas no santo daime, mas que nas giras do Reino do Sol ganham outro significado, sendo também utilizadas pelas entidades para a realização do atendimento espiritual.

\footnotetext{
24 Trecho do hino do santo daime "Senhora da paz", de autoria de Sérgio Correia, é uma referência exemplar do diálogo entre os dois sistemas religiosos.
} 
Arruda, manjericão, alecrim e alfazema são deixadas de molho em pratos de barro e utilizadas para aspergir água aromática nos consulentes.

Os elementos litúrgicos empregados no umbandaime variam em cada terreiro e igreja, mas servem sempre como suporte pela ambivalência simbólica adquirida em relação aos dois sistemas. Partindo do compartilhamento de algumas matrizes formadoras como o catolicismo popular e práticas que remontam a rituais indígenas, o ajuste desses elementos litúrgicos dentro da cosmologia do umbandaime se faz por um processo harmonioso, segundo alguns participantes ouvidos, por não se tratarem de coisas distintas, mas sim de um mesmo estudo, algo que possui uma abrangência que transcende as duas religiões.

A defumação possui um papel extremamente importante no umbandaime, ocorrendo diversas vezes em um mesmo ritual. Gê Marques ressalta a existência dessa prática já nas primeiras igrejas do santo daime em São Paulo, que vinha tradicionalmente acompanhada de um ponto de umbanda que ainda hoje é cantado em muitas igrejas:

\author{
Defuma esta casa \\ Bem defumada \\ Com a cruz de Deus \\ Ela vai ser rezada \\ Sou rezador \\ Sou filho de umbanda \\ Com a cruz de Deus \\ Todo mal se abranda
}

O sacerdote ressalta a preocupação existente no Reino do Sol com esse ato, evidenciado através de uma seleção cuidadosa das ervas e do momento mais indicado para a utilização de cada uma. Os momentos de defumação ficam à critério de cada casa, mas no caso do Reino do Sol eles remetem às mudanças de hinário, à abertura da banca ou à algum hino especial de chamada das entidades espirituais. Ainda assim, existe certo consenso entre os centros religiosos sobre a realização de uma defumação inicial, que visa o descarrego do espaço ritual, e a defumação final, que serviria para a 
limpeza espiritual de todas as energias que foram trabalhadas ali.

O critério utilizado para a defumação no terreiro Sete Pedreiras é bastante subjetivo, recaindo quase sempre sobre o comando da entidade espiritual que estiver no comando da sessão. Madrinha Natalina considera como uma das principais características da defumação sua capacidade de afastar espíritos ruins, ou seja, aqueles que na escala evolutiva da espiritualidade umbandista ainda não alcançaram a luz.

\begin{abstract}
ALVARO: E quando ela [a defumação] é realizada?
NATALINA: Quando a gente vê que está pesado. Quando vê que está muito pesado então vai um menino lá, vai uma pessoa lá, defuma tudo e fica mais leve[...]A defumação para nós ela se dá no intervalo, na metade dos trabalhos, quando o trabalho está muito pesado[...]A defumação é muito importante para afastar os maus fluídos, afastar as coisas ruins, afastar os zombeteiros ${ }^{25}$. Aí é fácil, eles não gostam[...]A defumação é muito importante.
\end{abstract}

A defumação faz parte da abertura das giras de umbandaime, habitualmente realizada após serem cantados os pontos de Exu e outros pontos de abertura que serão apresentados mais adiante. Essa defumação inicial remete ao modelo de culto umbandista ocorrendo também em mais dois ou três momentos no decorrer do ritual, como foi registrado no terreiro de Jorge Scritori.

No umbandaime de madrinha Natalina, essa prática ritual resulta na experiência de um culto feito na fumaça. Mais intensamente do que o observável em qualquer igreja do santo daime. Manifestações religiosas que constituem as matrizes formadoras do santo daime como a pajelança, e da umbanda, como a jurema, possuem a defumação ritual fortemente acentuada, o que lança luz sobre uma face desse diálogo.

Nas giras do Reino do Sol, o defumador não fica restrito ao salão. Ele circula pelo terreiro em frente à igreja no intuito de defumar os participantes do trabalho que estiverem em processo de limpeza espiritual - colocando as impurezas fora do corpo sobretudo através do vômito, ou mesmo descansando sentados nos troncos de árvore.

O defumador circula também em diversos momentos, não apenas quando são tocados os pontos específicos de defumação - como ocorre nos terreiros de umbanda do Pai Jamil e Sete Porteiras. Sempre respeitando o comando do sacerdote responsável

25 Categoria de espíritos não evoluídos que atrapalham o desenvolvimento do médium no trabalho. 
pelo culto que pode também ser o comando da entidade espiritual responsável por presidir o trabalho.

No momento em que o adepto se prepara para o início da sessão de umbandaime existe uma prática relativamente comum, que também é bastante difundida em rituais do santo daime, em que o participante se dirige ao Cruzeiro ${ }^{26}$ para firmar seu pensamento e, sobretudo no umbandaime, foi observado que alguns médiuns optam por colocar suas guias $^{27}$ no pescoço nesse local. Esse rito de se firmar ao pé do Cruzeiro possui grande importância dentro da doutrina daimista e constitui o início de uma transição para se acessar o mundo espiritual.

Faz parte da vestimenta ritual a cor branca, ou de tons claros como o algodão cru. Os homens usam calça e as mulheres saias compridas e largas. Todos participam do ritual descalços, na igreja, ou com os sapatos desamarrados, no terreiro. Essa atenção aos pés está ligada à uma concepção de "desprendimento" que busca facilitar a fluidez do corpo ou, em outras palavras, a "soltura do aparelho".

\footnotetext{
${ }^{26}$ O Cruzeiro é a classificação dada pela doutrina daimista à cruz de caravaca, cuja presença é obrigatória em todas as igrejas do santo daime, possuindo idiossincrasias variáveis dependendo do local de culto. É uma cruz semelhante à cruz católica, porém com um "braço" horizontal a mais, que simboliza o retorno de Cristo.

${ }^{27}$ Guias são os colares de contas que representam as principais entidades relacionada ao médium.
} 


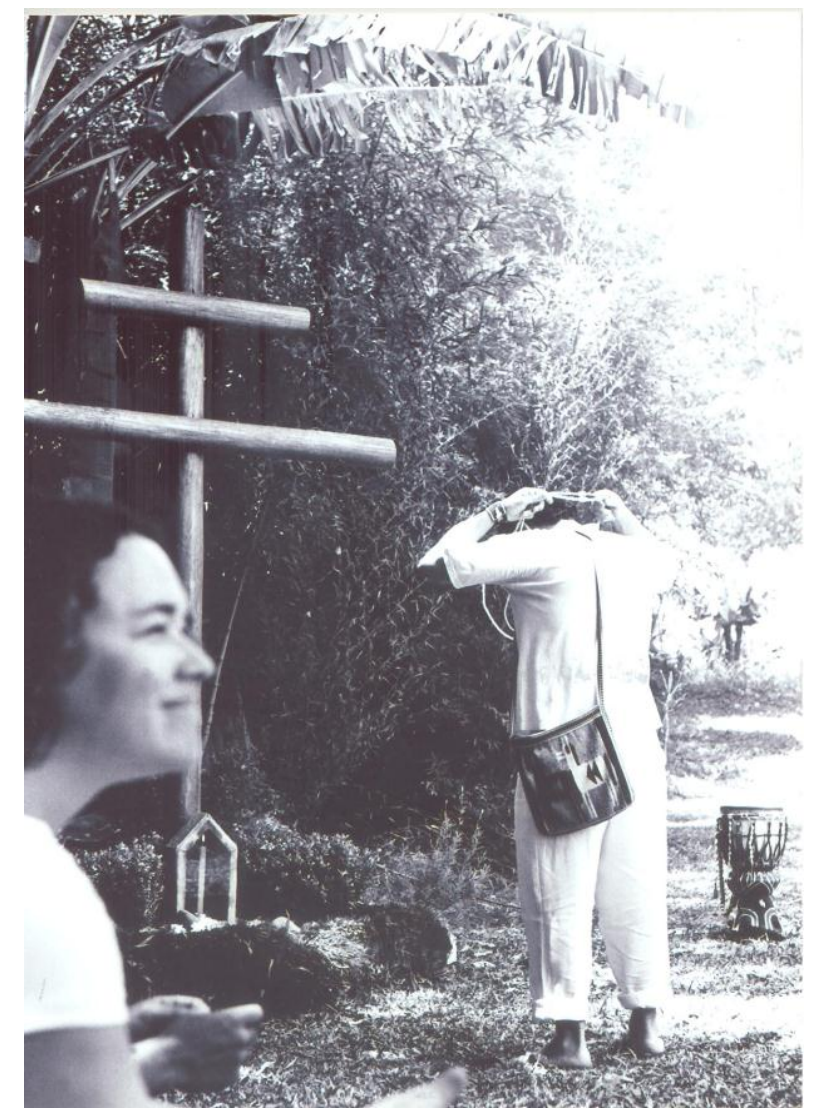

Figura 5 - Adepto inicia o rito de transição antes de entrar na igreja. Alvaro Russo, 2012. Reino do Sol

Os ritos de abertura no umbandaime seguem uma rotina bastante difundida nos cultos do santo daime. Após todos terem adentrado ao salão, onde será realizado o ritual, tem início a seguinte sequência:

\section{A forma tradicional com que se abre a maioria dos nossos trabalhos espirituais consta do sinal da cruz seguido[...] de três Pai Nossos e três Ave Marias no caso de hinários oficiais. Em seguida[...] lêe-se a Consagração do Aposento. ${ }^{28}$}

O sinal da cruz e as orações representam o encerramento do rito de transição, e a consequente entrada do participante num regime em que o cosmo seria transformado. O primeiro elemento seria o rito daimista de se firmar ao pé do Cruzeiro, situado do lado de fora da igreja. Em seguida, o rito de colocação das guias faria a conexão entre o

\footnotetext{
${ }^{28}$ CEFLURIS. Normas de Rituais. Disponível em <http://www.santodaime.it/Library/DOCTRINE/cefluris97_normas_portuguese.html>. Acesso em 09/2015.
} 
adepto e seus guias, através do sistema umbandista. O terceiro e último rito dessa transição para o espaço ritual e, note-se, espaço espiritual aqui faz referência ao espaço ritual no mundo ordinário e no astral, simultaneamente, trata-se do sinal da cruz seguido das orações católicas e espíritas, realizado com o adepto já posicionado no salão.

Após os ritos de transição que envolvem os sistemas daimista, umbandista, católico e espírita, passamos aos ritos de abertura, que iniciam o trabalho espiritual ou, em outras palavras, o ritual passaria a operar em dois mundos simultaneamente, no mundo ordinário e no astral. O primeiro rito de abertura consiste em comungar a bebida sacramental, o daime. Faz-se o sinal da cruz, recebe-se o copo e toma-se a dose oferecida até o final.

Os ritos de abertura são compostos fazendo-se referência aos mesmos sistemas religiosos mobilizados nos ritos de transição. $\mathrm{O}$ sinal da cruz marca o início dos ritos de abertura, articulando com o catolicismo. $\mathrm{O}$ rito de comungar a bebida representa, de forma bastante pronunciada, o sistema daimista. Após todos terem voltado a seus lugares é realizado o rito espírita, através das preces de abertura ${ }^{29}$. Os ritos de abertura terminam com os pontos de abertura da umbanda, que marcam a presença do sistema umbandista nos ritos de abertura. A partir desse momento a gira é considerada aberta, ou seja, o salão é defumado e começa-se a cantar para as entidades.

No desenvolvimento do ritual de umbandaime, a chamada das entidades segue uma estruturação que marca a mudança das $\operatorname{linhas}^{30}$ que estão sendo trabalhadas. Uma linha é iniciada através de um ou mais pontos de chamada em que é anunciada, ou provocada, a "descida" da entidade correspondente. Após o início da linha, pode ser feita a transição para outras entidades relacionadas. A linha aberta opera como parâmetro que dá suporte para diferentes diálogos, por exemplo, ao iniciar-se a linha de Oxalá pode ocorrer o trânsito para os Caboclos de Oxalá. O final de cada linha é marcado pelos pontos de subida como, por exemplo, nesse ponto de subida dos caboclos:

\footnotetext{
${ }^{29}$ Ver mais detalhadamente as preces espíritas de abertura no próximo capítulo.

${ }^{30}$ A umbanda é dividida em 7 linhas: Xangô, Ogum, Oxalá, Iemanjá, Oxum, Oxóssi e Obaluaê.
} 
É na boca da mata

É na boca da mata

Que eles moram

Quando os caboclos se despedem

E vão embora

Os rituais de umbandaime operam um trânsito por todas as 7 linhas da umbanda através dessa mesma estrutura de chamada, transições e subida das entidades. Não existe uma sequência de linhas pré-estabelecida nos rituais de umbandaime, de acordo com os 4 sacerdotes entrevistados. Não há sequência, mas foi constatado nas observações a proeminência da linha de Oxóssi e dos caboclos nos rituais. Isso pôde ser constatado de diferentes formas, em alguns casos é notável a recorrência da entidade ao longo do ritual, quando canta-se para os caboclos em diversos momentos, ou como ocorre em outros casos, essa inclinação ao culto do caboclo é perceptível sobretudo devido ao momento de chamada dessa linha no desenvolvimento da gira, que coincide normalmente com o meio do trabalho que pode também ser interpretado como clímax do ritual.

O fechamento da gira, assim como a abertura, é marcado por uma série estabelecida de ritos que visam a separação dos mundos distintos que foram aproximados durante o trabalho. Inicia-se com um ou mais pontos umbandistas de encerramento e, dependendo do local, pode haver também alguns hinos daimistas. Fazse então a prece espírita para o encerramento seguida das orações católicas, três paisnossos, três aves-marias, um salve-rainha e, em alguns casos, a Prece de Cáritas. É mantido também o rito daimista seguindo-se o encerramento da sessão por Juramidam $^{31}$.

Nesse momento, com a sessão já encerrada, consolida-se o afastamento entre mundo astral e mundo terreno com uma sequência de vivas, característicos do encerramento dos trabalhos da doutrina daimista, com algumas poucas exceções ${ }^{32}$.

\footnotetext{
${ }^{31}$ Ver o encerramento da sessão por Juramidam com maior detalhamento no próximo capítulo.

${ }^{32}$ Os vivas sempre são dados pelo presidente da mesa, comandante do trabalho ou pessoa previamente designada para tal. Quem os dá deve estar de pé, preferencialmente de frente ao Cruzeiro. Com ele saudase o festejo do dia. (Todos podem responder aos vivas, especialmente o lado masculino). Devem ser evitados: nos trabalhos de cura e Concentração, durante os hinários antes de ser cantada a Confissão e na Quinta-feira Santa e Dia de Finados. Pode-se saudar os elementos da natureza, o dono do hinário que
} 
Existe uma sequência de "vivas" considerada obrigatória: Ao Divino Pai Eterno, a Rainha da Floresta, Jesus Cristo Redentor, o Patriarca São José, todos os Seres Divinos, o Nosso Mestre Império, toda a Irmandade, o Santo Cruzeiro.

Podemos analisar o fechamento da sessão através de uma transição gradual, que começa com a subida da última linha trabalhada na sessão, que normalmente é uma linha fria $^{33}$. Após a subida dessa linha da umbanda, que habitualmente são os Erês ou então Oxalá, vem o rito de encerramento umbandista, com um ponto de encerramento. É nesse momento que os médiuns retiram suas guias do pescoço, marcando o rito de fechamento umbandista. Segue-se para o encerramento daimista, com os hinos, quando é o caso. Completam o rito de encerramento da sessão a prece de encerramento, referente ao sistema espírita, que vem acompanhada das orações católicas completando, assim, o rito de encerramento da sessão.

Realiza-se, dessa forma, a consolidaćão da boa distância entre mundo astral e mundo ordinário, nem próximos nem distantes demais, que culmina em uma manifestacão de alegria generalizada através dos vivas, seguido das palmas dos participantes, e terminando com os abraços das pessoas que estão mais próximas. A atmosfera leve e alegre que toma conta do ambiente após o ritual deve-se, ao menos em parte, a sensacão de ter-se aproximado o suficente do mundo astral para saber que sua existência afetou diretamente a ordem desse mundo e, ao mesmo tempo, ter-se reaproximado do mundo ordinário, sabendo-se agora que o mundo astral não está tão distante quanto estava antes da gira e nem tão perto quanto esteve durante o ritual.

esteja sendo cantado, igrejas ou comunidades, visitantes e aniversariantes.
(fonte:http://www.santodaime.it/Library/DOCTRINE/cefluris97_normas_portuguese.html)
33 Linhas frias como Oxalá e Iemanjá devem ser pensadas em oposição às linhas quentes, como Xangô e
Iansâ. Tal classificação se deve a própria natureza dos orixás onde é possível dividi-los em mais e menos efusivos. 


\section{Capítulo II - A chamada das Linhas}

\section{O dono do ponto é o guia, o hino tem autoria - uma análise da música e da dança}

Nos rituais de umbandaime os pontos e os hinos do santo daime possuem um papel central no que se refere à estrutura ritual. É através dos pontos e dos hinos, mas principalmente dos pontos, que as entidades são chamadas e as incorporações são contextualizadas. A musicalidade compõe a estrutura essencial do umbandaime, pois o ritual é inteiramente cantado e tocado, com exceções muito pontuais ${ }^{34}$.

As giras de umbandaime são iniciadas com orações, três pais-nossos e três avemarias seguidos, na maioria dos casos, pela oração daimista "Chave de Harmonia":

"Desejo Harmonia, Amor, Verdade e Justiça a todos os meus irmãos. Com as forças reunidas das silenciosas vibrações dos nossos pensamentos, somos fortes, sadios e felizes, formando assim um elo de fraternidade universal.

Estou satisfeito e em paz com o universo inteiro e desejo que todos os seres realizem as suas aspirações mais íntimas. Dou graças ao Pai invisível por ter estabelecido a Harmonia, o Amor, a Verdade e a Justiça entre todos os seus filhos. Assim seja. Amém.”

Após essas orações iniciais ocorre o "despacho",35 de daime, momento em que todos são convidados a comungar o daime. Realizado o despacho, pode ou não ser feita mais uma oração, a Prece para o começo da reunião, ficando ao critério de cada centro a sua realização e que, aparentemente, não é muito executada nos centros visitados nessa pesquisa.

Ao Senhor Deus Todo Poderoso pedimos que envie bons espíritos

\footnotetext{
${ }^{34}$ A essas exceções à regra da musicalidade cito alguns exercícios que presenciei no Reino do Sol em que diferentes dinâmicas que envolviam o silêncio por vezes intercalavam-se à música e ao canto.

${ }^{35}$ Despacho, no sistema religioso daimista, nomeia o momento em que a bebida sacramental é servida durante o ritual quando o despacho é anunciado aberto pelo comando espiritual da sessão.
} 
para nos assistirem, que afaste os que puderem induzir-nos ao erro, e que nos dê a Luz de que precisamos para distinguir a verdade da impostura.

Afastai de nós também, Senhor, os espíritos malévolos, encarnados ou desencarnados, que tentem lançar a desunião entre nós e, bem assim, desviar-nos da caridade e do amor do próximo. Se alguns procurarem introduzir-se aqui, fazei Senhor, que não achem acesso em nossos corações.

Bons espíritos que vos dignais vir instruir-nos, tornai-nos dóceis aos vossos conselhos, isentai-nos de qualquer pensamento de egoísmo, de orgulho, de inveja e de ciúme; inspirai-nos indulgência e benevolência para com os nossos semelhantes, presentes ou ausentes, amigos ou inimigos; fazei, enfim, que pelos sentimentos que nos animam reconheçamos a vossa salutar influência.

Dai aos médiuns que encarregardes de nos transmitir os vossos ensinamentos, consciência da santidade do mandato que lhes é confiado e da gravidade do ato que vão desempenhar, a fim de que o pratiquem com fervor e reconhecimento necessário.

Se entre nós se encontrarem pessoas dominadas por sentimentos que não sejam do bem, abrir-lhes os olhos à Luz e perdoai-lhes como the perdoamos, se por ventura trazem malévolas intenções.

Pedimos especialmente a nosso guia espiritual São João Batista que nos assista e por nós vele.

(Alan Kardec)

E da mesma forma pode ocorrer ou não a execução de alguns poucos hinos daimistas para serem bailados, seguidos de outra prece espírita intitulada "Prece para os médiuns" presente na estrutura dos cultos daimistas de um modo geral.

Deus Onipotente, permiti que os bons espíritos me assistam na comunicação que solicito. Preservai-me da presunção de me acreditar ao abrigo dos maus espíritos, do orgulho que poderia induzir-me ao erro acerca do valor que obtenho, de todo sentimento contrário à caridade para com os outros médiuns.

Se for levado ao erro, inspirai a alguém o pensamento de advertir-me, e dai-me humildade para receber, cheio de reconhecimento, a crítica que me 
façam, para tomar por dados a mim mesmo, e não os outros, os conselhos que os bons espíritos hajam por bem ditar-me. Se me vir tentado a abusar, seja no que for, ou me envaidecer da faculdade que vos aprouve concederme, eu vos peço que me retireis antes que consintais se afaste ela do seu fim providencial, que é o bem de todos e o meu próprio adiantamento moral"

Todo ritual de umbandaime possui um ponto ou curimba que marca a abertura. O que não é fixo é a entidade a quem se dedica esse primeiro ponto de abertura, podendo ser Exu, o que ocorre na maioria dos rituais observados, mas pode ser também dedicado à Oxalá. Citarei alguns que foram utilizados nos rituais observados sendo os dois primeiros dedicados a Exu, o mensageiro das religiões afro-brasileiras, e o último dedicado a Oxalá que na umbanda também pode ser representado como Jesus Cristo, o mensageiro do catolicismo:

O sino da igrejinha faz belém blem blem

O sino da igrejinha faz belém blem blem

Deu meia-noite o galo já cantou

Séo Tranca Rua que é dono da gira

Oh corre gira que Ogum mandou

Santo Antônio é pequenino

amansador de burro bravo.

Quem mexer com tranca-rua

vai mexer com o diabo

(alternando para Maria Padilha)

"Senhor do mundo

Oxalá meu pai

Baixai, baixai na umbanda meu senhor

E a nossa terra iluminai 


\section{Vamos pedir licença a Deus \\ Nosso Senhor \\ Para os trabalhos começar}

Note-se que a dupla possibilidade para o ponto de abertura faz-se viável pois, dependendo do sistema religioso a partir do qual se organiza os pontos de abertura, é possível que o mensageiro afro-brasileiro seja intercambiado com o mensageiro cristão. Esse ponto de abertura é habitualmente seguido de outros dois ou três pontos de umbanda que compõem o que chamarei de pontos de abertura como, por exemplo:

Pai vou pedir licença a Deus

E meio mundo governar

Ou meio Sol, ou meia Lua

Ou meia Terra, ou meio Mar

Pai vou pedir licença a Deus

E meio mundo governar

Ou meio Sol, ou meia Lua

Ou meia Terra, ou meio Mar

Os pretos-velhos e os caboclos

Vamos todos Saravá

Vamos pedir licença a deus nosso Senhor

Para os trabalhos começar

Vou abrir minha Jurema

Vou abrir meu Juremá

Com a licença de Mamãe Oxum

E do meu Pai Oxalá 
Refletiu a luz divina

Com todo seu esplendor

Vem do Reino de Oxalá

Onde há paz e o amor

Luz que refletiu na terra

Luz que refletiu no ar

Luz que veio de Aruanda

Para tudo iluminar

A umbanda é paz e amor

Um mundo cheio de luz

É força que nos dá vida

E a bandeira que conduz

Avante filhos de fé

Como nossa lei não há

Levando ao mundo inteiro

A bandeira de Oxalá

(hino da umbanda)

Essa sequência de abertura característica dos rituais umbandistas é seguida da defumação, que ocorre no momento de abertura em todos rituais de umbandaime observados. O momento da defumação é marcado pelo início de algum ponto de defumação como, por exemplo:

Corre gira pai Ogum

Filho quer se defumar

Umbanda tem fundamento

É preciso preparar

Com incenso e benjoim

Alecrim e alfazema

Filho quer se defumar

Com as ervas da Jurema 
Defuma, defumador

Essa casa de nosso senhor

Leva pras ondas do mar

O mal que aqui possa estar

O umbandaime realizado na igreja de santo daime, adota uma abertura estruturada dos ritos daimistas, em geral através das preces espíritas seguidas do que chamaria de uma síntese dos bailados. Os bailados são trabalhos daimistas caracterizados como de banca fechada, ou seja, não visam a incorporação. Existem trabalhos do santo daime em que a incorporação é permitida, caracterizados como de banca aberta, como os trabalhos de São Miguel, de mesa-branca e as giras ${ }^{36}$.

No terreiro de umbanda de madrinha Natalina a abertura não conta com os hinos bailados e as preces não são realizadas de forma sistemática, porém a estrutura dos pontos de abertura é recorrente tanto nesse terreiro quanto na igreja de santo daime. Quando é feita uma comparação entre a gira no terreiro e a gira realizada na igreja de santo daime, notamos algumas semelhanças entre as aberturas dos trabalhos, que aqui considero como todas as práticas rituais que antecedem o chamado das linhas da umbanda.

Podem ser adicionados pontos dedicados a outros orixás que assumem a responsabilidade espiritual do trabalho e são louvados entre os primeiros cânticos, como forma de reverência. Entre os rituais observados, os orixás Oxóssi e Oxalá e a cabocla Jurema receberam atenção especial durante o processo de abertura dos trabalhos, pois eles estariam mais relacionados a chefia espiritual da casa ou também a contextos específicos do calendário dos santos, quando ocorrem giras dedicadas a determinadas entidades.

Após a abertura, encontramos um novo contraste entre o terreiro e a igreja. Nas giras com daime que ocorrem no Reino do Sol, inicia-se o chamado das entidades

\footnotetext{
${ }^{36}$ Mesmo sendo um trabalho daimista introduzido pelo Padrinho Sebastião em intercâmbio com um terreiro carioca da mãe de santo Baixinha do Lumiar, são poucas igrejas que realizam as giras. As giras não possuem uma data específica no calendário oficial e nem uma obrigatoriedade, pelo contrário, encontram uma considerável resistência por grande parte das igrejas do CEFLURIS.
} 
habitualmente cantando-se para Oxalá enquanto que no Sete Pedreiras encerra-se a gira com esse orixá. No desenvolvimento da gira não é possível falar em uma sequência préestabelecida de entidades, mas alguns traços mais marcantes podem ser mencionados.

No panteão mobilizado durante as giras que envolve orixás, santos católicos, entidades da umbanda, seres da natureza além da devoção a mestre Irineu e padrinho Sebastião, é significativa a relevância e a saliência ritual dos caboclos. Nas giras com daime observadas no Reino do Sol, os pontos de caboclo são cantados em diversos momentos do ritual. Essa entidade irrompe em praticamente todas as linhas de forma dualista ou, usando uma categoria nativa, cruzada $^{37}$.

A linha de Oxalá possui seus caboclos como, por exemplo, Pena Branca, que é chamado logo após cantar-se para Oxalá. Da mesma forma, Sete Flechas que pertence à linha de Oxóssi vem imediatamente após a chamada desse orixá. O mesmo ocorre com os orixás das outras linhas, Ogum, Xangô, Oxum, Iemanjá, todos eles possuindo seus caboclos específicos que são chamados no momento de culto das respectivas linhas.

No templo Sete Pedreiras, porém, não ocorre esse livre trânsito empreendido pela categoria caboclo entre as diversas linhas da umbanda que são evocadas durante o ritual. Mas é possível verificar que os caboclos são chamados exatamente na metade da gira, logo após o $3^{\circ}$ despacho de daime. É um momento em que o ritual atinge seu ponto máximo, marcado pelo último despacho de daime da sessão.

O encerramento também possui alguns elementos invariáveis quando comparamos a gira com daime no terreiro Sete Pedreiras e a gira do Reino do Sol. No terreiro existe uma sequência de pontos bastante característica dos fechamentos de trabalhos umbandistas, enquanto que a igreja daimista adota uma sequência de hinos bailados que fazem parte de uma estrutura de encerramento bastante particular.

A parcela recorrente nos dois modelos rituais com relação ao encerramento fica por conta das orações realizadas; três pais-nossos, três aves-marias e um salve-rainha, que são invariáveis tanto no terreiro quanto na igreja. A prece espírita denominada Prece para o encerramento da reunião pode ou não ser realizada, dependendo do centro e do ritual:

${ }^{37}$ Um exemplo de entidade cruzada é Ogum-Xoroquê, metade Exu e metade Ogum. 
Agradecemos aos bons espíritos que anuíram em vir comunicar-se conosco e lhes pedimos que nos ajudem a pôr em prática as instruções que nos deram e façam com que ao sairmos daqui cada um de nós se sinta fortalecido na prática do bem e do amor ao próximo.

Desejamos igualmente que as instruções que recebemos sejam proveitosas aos espíritos sofredores, ignorantes ou viciosos, que hajam assistido à nossa reunião, espíritos esses para os quais imploramos misericórdia de Deus.

O encerramento da sessão por Juramidam, que é uma oração estruturante da doutrina daimista, faz parte do fechamento de todos os trabalhos do santo daime, assim como integra também o encerramento dos rituais de umbandaime observados:

Em nome de Deus Pai Todo Poderoso, da Virgem Soberana. Mãe, do Patriarca São José e de todos os Seres Divinos da Corte Celestial e com a Ordem do nosso Mestre Império Juramidam está encerrado o nosso trabalho, meus irmãos e minhas irmãs. Louvado seja Deus nas alturas."

[E todos respondem]: Para que sempre seja louvada a Nossa Mãe Maria Santíssima sobre toda a humanidade. Amém. ${ }^{38}$

Uma questão enfatizada por pai Dalmo, e que aqui tomo liberdade de reproduzir, diz respeito à autoria dos hinos daimistas. Diferentemente dos pontos de umbanda que não teriam a autoria de um indivíduo, pertencendo ao domínio público do conhecimento popular, estaria ainda assim sujeito às idiossincrasias correspondentes ao terreiro onde é cantado. O que pode ser entendido como uma espécie de timbre local em que cada centro religioso imprimi sua personalidade tanto na melodia como na poesia do ponto.

No santo daime ocorre que os padrinhos, as madrinhas ou alguns frequentadores recebem hinos ou até mesmo hinários completos do astral através de revelações. No culto umbandista entretanto um ponto não adquire relevância por ter sido recebido por alguém específico, o autor ou os autores são objetos dos pontos e não

38 fonte:http://www.santodaime.it/Library/DOCTRINE/cefluris97_normas_portuguese.html 
sujeitos. O que se observa é que a importância ressaltada pelos adeptos está na antiguidade da utilização do ponto, como se o tempo nesse caso fosse o principal artista responsável sobretudo pela validação através da prática ritual.

Essa valorização da antiguidade dos pontos como forma até mesmo de prestígio aparece de forma contrastiva com a questão autoral que envolve os hinos daimistas, como foi enunciado durante uma das entrevistas por pai Dalmo. O sacerdote também aponta para o prestígio contido na antiguidade dos pontos mencionando que um dos pontos de abertura das giras do Reino do Sol era cantado em terreiros pioneiros da religião umbandista, como o terreiro de pai Jaú que se encontrava em atividade já na década de 1930, considerado um grande legitimador dessa ancestralidade musical.

No relato de pai Dalmo:

...A umbanda é mais presa ao que já foi cantado [...] ninguém tem ousadia de chegar e falar: esse hino foi eu quem recebi. [O que é dito é:] Canta-se [este ponto] na casa de fulano, canta-se na casa de ciclano. Mas é universal, não tem dono. O que ocorre é que o dono do ponto é o guia.

Uma diferença marcante do umbandaime em relação à umbanda se refere aos ogãs ou alabês. Tradicionalmente nos terreiros de candomblé o atabaque é um instrumento exclusivamente masculino, representando um tabu para as mulheres. Porém na umbanda e também nas giras de umbandaime, as mulheres assumem os atabaques, tanto no Sete Pedreiras quanto no Reino do Sol. Essa equivalência dos gêneros na questão musical estende-se para outros instrumentos utilizados nos rituais.

Essa maior abertura musical da umbanda pode ser notada de outras maneiras como, por exemplo, na existência de uma aceitação de diferentes instrumentos, o que proporciona uma extensa lista contendo uma imensa diversidade de timbres. Apesar dos atabaques constituírem o pilar musical das giras com daime, outros instrumentos são utilizados para compor a musicalidade ritual. Acordeon, agogô, violão, pandeiro e maracá fazem parte dessa orquestra diversificada, o que demonstra também sua abertura do espectro musical no acolhimento de instrumentos utilizados no santo daime, na umbanda e em outras manifestações populares como, por exemplo, as alfaias do maracatu e os berimbaus da capoeira.

A expressão corporal realizada nos rituais de umbandaime possui um papel 
fundamental, segundo os entrevistados, para compor ou até mesmo protagonizar a experiência da incorporação. A ginga ${ }^{39}$, expressão corporal característica dos rituais de umbanda, apesar de não ser obrigatória como é a dança em um bailado do santo daime, é enfaticamente recomendada nos centros religiosos por proporcionar uma soltura do aparelho, de acordo com Gê Marques, que pode estar relacionada a uma alteração de consciência que compreende uma nova consciência corporal com outras possibilidades gestuais, conforme relatou pai Dalmo.

De acordo com o relato de Gê Marques:

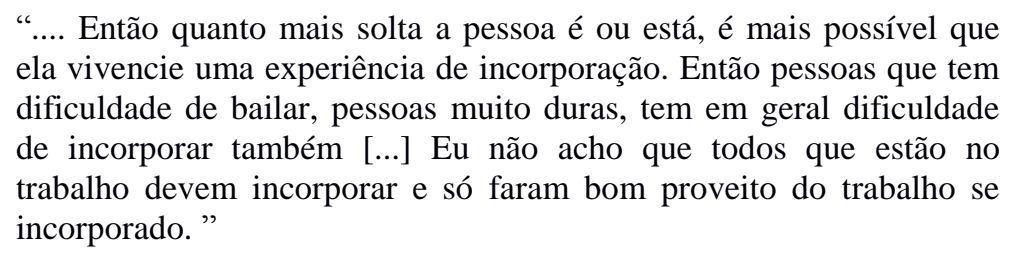

A dança não só viabiliza a incorporação como também constitui a manifestação de algumas entidades. A dança como expressão corporal de algumas entidades surge no discurso de Jorge Scritori, onde ressalta que essa expressão pode se dar de duas formas distintas. A primeira seria a manifestação de forças que falam, e uma outra forma de expressão seria aquela que envolve as forças que não tem o hábito de falar o que, de acordo com o pai de santo, implicaria no fato dessas forças possuírem um escopo de movimento maior que as outras.

\footnotetext{
${ }^{39}$ A ginga consiste em um passo de dança utilizado para acompanhar o ritmo dos pontos. Diferentemente do bailado, que seria um movimento mais marcado, a ginga estaria, de certa forma, mais próxima do movimento básico da capoeira, porém de forma mais contida.
} 


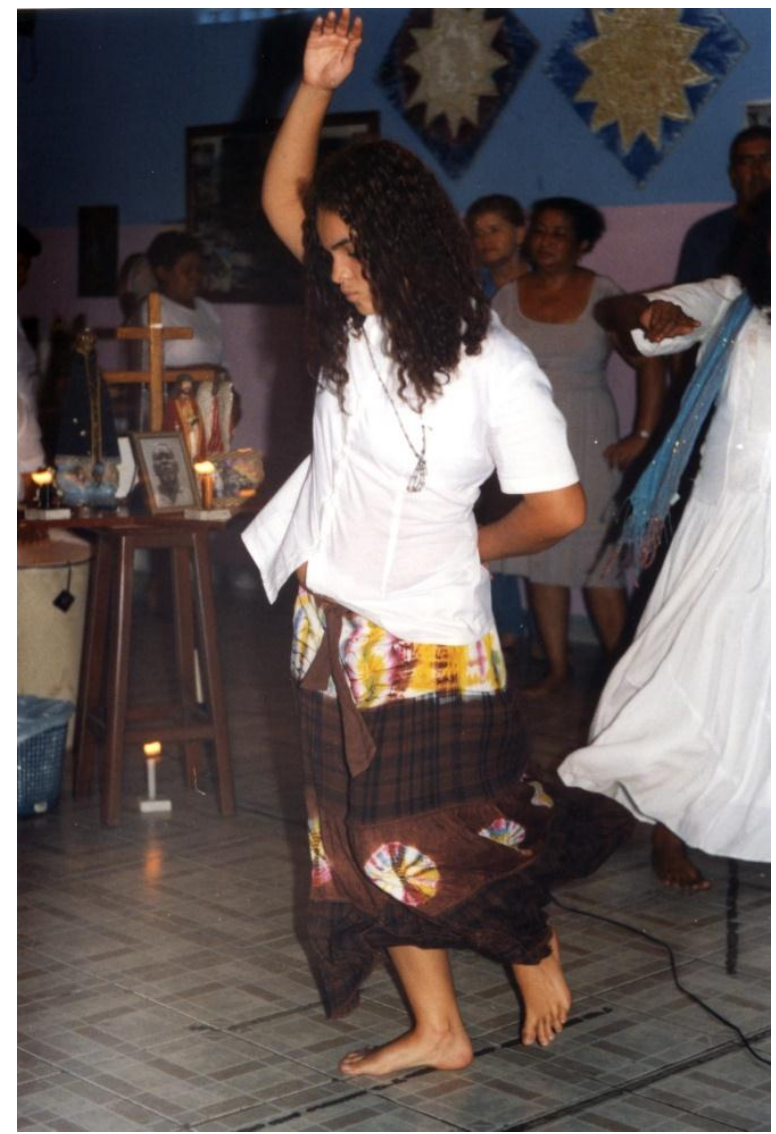

Figura 6 - Mulher gingando durante uma gira no 7 Pedreiras. Alvaro Russo, 2012. Sete Pedreiras

O caráter de limpeza e descarrego do aparelho também está associado à dança, ou à ginga. Madrinha Natalina ressalta essa dimensão afirmando que "a gente expulsa as coisas dançando". 


\section{Exus, pretos-velhos e caboclos: as linhas estão abertas}

As entidades espirituais da umbanda e do santo daime, agrupadas respectivamente nos dois sistemas religiosos, possuem em comum a característica de receberem contornos específicos de acordo com cada terreiro ou igreja onde os rituais ocorrem. Quando se transita de um lugar para outro, entidades surgem, desaparecem ou trocam de lugar na hierarquia.

A umbanda se manifesta no umbandaime através das principais categorias de entidades e orixás do seu panteão, tanto as da esquerda concebidas como entidades sem luz como as da direita tidas como iluminadas. Dentro deste vasto panteão umbandista os caboclos e os pretos-velhos assumem uma posição de grande destaque. Essa proeminente categoria se manifesta em diferentes esferas do culto do umbandaime que variam entre os locais de culto, mas mantem-se apesar das idiossincrasias uma ligação bastante forte com essas entidades, sobretudo com os caboclos.

No Reino do Sol é atribuído ao caboclo Águia Dourada o início das giras, antes mesmo da fundação da casa. Essa entidade esteve à frente dos trabalhos espirituais no Reino do Sol durante muitos anos, desde o início dos encontros para o desenvolvimento dos estudos umbandistas. Nas palavras de Gê Marques, a consolidação da igreja que se deu posteriormente consagrou-se como uma casa para viabilizar a manifestação dos caboclos. A igreja possui também afinidade com outros caboclos como Tupinambá e Pena Branca, ficando ao encargo deste último o atual comando espiritual do centro.

Essa afinidade se estende para a dinâmica ritual durante as giras, quando os caboclos são chamados em diversos momentos dentro de praticamente todas as linhas que se manifestam no salão. Nesse terreiro que me deparei com a maior variedade de caboclos entre os centros pesquisados chegando ao ponto de muitos deles se identificarem a partir dessa dualidade. Dessa forma, era algo relativamente comum nesse centro a autodefinição das entidades a partir de categorias como Caboclo de Oxumaré, Cabocla de Oxum etc.

No terreiro Sete Pedreiras, padrinho Sebastião também ocupa lugar de destaque no panteão, porém nesse terreiro ele é considerado como uma manifestação de Oxóssi, orixá que possui lugar de destaque na mesa em formato de estrela, sendo representado por uma imagem de São Sebastião com cerca de $40 \mathrm{~cm}$ de altura. 
Um dos contornos particulares que o panteão assume em cada centro religioso pode ser percebido através de uma entidade definida por Jorge Scritori como mestre da Jurema e que se manifesta no terreiro Sete Porteiras. Mestre Ladislau foi um ayahuasqueiro durante sua vida e inciou sua trajetória errante na América Central, passou pelo Tambor de Mina e pelo nordeste brasileiro, sempre carregando em suas manifestações todas essas características. Segundo o pai de santo Jorge Scritori, o daime possibilitou a ele a oportunidade de trabalhar com entidades da Jurema.

Essas entidades diversas convivem no panteão do umbandaime com outras que fazem parte do santo daime e da religiosidade ribeirinha, como os encantados, do mundo indígena, como os seres da natureza, além de mestre Irineu e padrinho Sebastião que representam forças às vezes classificadas como mentores espirituais, como ocorre no terreiro de madrinha Natalina. Na igreja do santo daime, mestre Irineu ocupa uma posição de regente da doutrina exercendo sua autoridade espiritual nos rituais.

O panteão do santo daime é constituído por elementos do catolicismo popular que se baseia em uma hierarquia onde o deus cristão ocupa o ponto mais alto com a Santíssima Trindade, Virgem Maria, Nossa Senhora da Conceição. Seguidos pela categoria dos santos, importantes mediadores entre os fiéis e o deus criador, assumem papel de destaque nesse sistema religioso onde são louvados sobretudo através nas datas festivas. Nessa categoria destacam-se São João, Santo Antônio, São José, São Sebastião, São Pedro. Também os anjos e arcanjos integram esse panteão, com destaque para os arcanjos São Miguel e Rafael, além dos anjos Gabriel, Ariel, Amael e Azael. Existe também uma parte do panteão composta por entidades advindas da religiosidade cabocla como Curupipipiraguá, Formosa e Tucum. Algumas entidades da religiosidade afro-brasileira também fazem parte da cosmologia daimista, sobretudo da linha do padrinho Sebastião onde destaca-se Ogum Beira-mar, Exu Tranca-Ruas e a orixá Iemanjá. Também fazem parte do panteão, figurando como comandantes espirituais da doutrina, mestre Irineu e padrinho Sebastião. Nessa hierarquia, advinda da lógica kardecista de evolução cármica, temos a seguinte estrutura do panteão, que mantêm uma lógica evolucionista que vai do mais ao menos evoluído: Santíssima Trindade / Santos e Anjos / Orixás - Encantados e Comandantes / Ogum Beira-mar / Exus.

A umbanda possui um panteão que, de forma similar ao santo daime, coloca os elementos católicos na posição mais elevada da hierarquia. Os orixás estão abaixo dos 
santos católicos seguidos das entidades, ou seja, dos espíritos desencarnados, dentre os quais os pretos-velhos e os caboclos são considerados mais evoluídos, portanto da direita e da luz, em contraposição aos Exus e Pombagiras, que compõe a esquerda e são considerados entidades sem luz. A escada evolutiva da umbanda figura da seguinte forma: Santíssima Trindade / Santos e Anjos / Orixás / Caboclos - Pretos-velhos / Exus / Eguns ${ }^{40}$.

O panteão do umbandaime envolveria elementos tanto da umbanda quanto do santo daime, aproximando termos dentro de um terceiro sistema. Essas aproximações são possibilitadas pelas analogias estruturais que envolvem tanto o panteão do santo daime quanto o panteão da umbanda. A relação de hierarquia das entidades no panteão do umbandaime seguiria o modelo: Santíssima Trindade/ Santos e Anjos / Orixás Encantados / Caboclos - Pretos-velhos - Ogum Beira-mar / Mestres / Exus.

Nesse panteão as entidades foram agrupadas em categorias, começando pela Santíssima Trindade, expoentes máximos do cristianismo, seguidos de Santos e Anjos, com destaque para Nossa Senhora da Conceição, que revelou a doutrina daimista para mestre Irineu sendo também conhecida como "Rainha da Floresta" ou "Rainha das Flores".

Os orixás, que passam a adentrar ao panteão do santo daime de forma significativa somente a partir do final da década de 60, compartilhando uma cosmologia que já abrigava os encantados e os elementos da natureza, que já haviam sido introduzidos por mestre Irineu na doutrina. O agrupamento dos Caboclos, Pretos-velhos e Ogum Beira-mar na mesma categoria é justificado por tratar-se de entidades que se utilizam da palavra como ferramenta da mediação quando incorporadas em seus médiuns. A palavra como mediação é verificada entre os Caboclos e Pretos-velhos através dos atendimentos aos consulentes e, no caso de Ogum Beira-mar, pela doutrinação do Exu Tranca-ruas, que em determinada passagem, narrada em seus mínimos detalhes no trabalho de Marques Júnior (2007) estabelece um pacto com padrinho Sebastião que o coloca como guardião da doutrina e das igrejas.

Mestre Irineu e Padrinho Sebastião assumem o papel de mestres espirituais da doutrina e exercem seu comando do astral. São considerados seres de muita luz e, como

\footnotetext{
${ }^{40}$ Eguns, nesse caso, faz referência aos espíritos dos mortos que representam o ponto menos evoluído na divisão do panteão umbandista
} 
será demonstrado, são considerados próximos aos Caboclos e Pretos-velhos. Os Exus, apesar de serem Exus doutrinados, ou seja, não são mais Exus pagãos, ainda constituem a esquerda e, portanto, a categoria menos evoluída espiritualmente.

Quando nos aproximamos do sistema simbólico umbandista, mestre Irineu assume um papel semelhante ao das entidades, porém em alguns casos sua classificação no panteão é imprecisa. O principal fator que o aproxima das entidades umbandistas é sua manifestação através da incorporação, o que não ocorre quando nos aproximamos do sistema simbólico do santo daime.

O sistema umbandista possui essa capacidade extremamente plástica, no que diz respeito a englobar novos elementos que são remetidos à estrutura existente transformando-a. Em algumas entrevistas com pais e mães de santo é nítida e, às vezes até mesmo explícita, a aproximação do mestre Irineu com entidades umbandistas, no caso os pretos-velhos.

Vale ressaltar que os pretos-velhos na umbanda possuem temperamento oposto aos caboclos, pois enquanto estes são demandeiros e voluntariosos, aqueles são pacíficos e humildes. Dentro de seu estilo, o preto-velho faz tudo o que o caboclo faz, inclusive e principalmente curas, pois também conhece o segredo das matas (Negrão, 1996; p. 213, 214).

O pai de santo Jorge Scritori nos fornece o relato de sua primeira miração em que transparece essa analogia:

[...]eu tive uma sensação estranha no corpo e de repente vi um senhor entrando na sala onde nós estávamos. Um senhor negro, muito grande. $\mathrm{E}$ aquilo me assustou muito porque ele estava com uma vestimenta que não era branca. Era aquela cor de uniforme...de raspa, que a gente fala. E ele estendeu o braço na minha direção e a mão lembrava uma pá, de tão grande que era. E ele passava a mão na minha cabeça e falava assim: eu te perdoo pela sua ignorância e eu vou te aceitar no meu caminho. E aquilo mexeu tanto comigo que eu passei horas chorando naquele trabalho só com aquela imagem [...]. [Um amigo] falou, olha: você teve uma miração aparentemente com o mestre Irineu que é um dos precursores, um dos organizadores... 
Uma aproximação às categorias existentes na umbanda também se manifesta entre o padrinho Sebastião e o caboclo umbandista. Essa analogia com o caboclo é devedora em parte do pertencimento de padrinho Sebastião aos ditos "povos da floresta" através do imaginário criado ao redor dos ex-seringueiros fundadores da doutrina daimista.

É comum fazer-se referência aos povos da floresta enquanto caboclos. A figura do caboclo amazônico remete, em grande medida, às populações ribeirinhas e extrativistas que habitam os distantes igarapés ou, através de contínuos movimentos migratórios desde o fim do ciclo da borracha, instalaram-se na periferia de Rio Branco e de outras cidades.

O caboclo que o adepto da doutrina daimista passa ter contato ao visitar o Céu do Mapiá, considerada a igreja-mãe do CEFLURIS, ou a qualquer outra comunidade religiosa ayahuasqueira nos inúmeros igarapés da região do piemonte amazônico, irá se deparar com um caboclo distinto do caboclo romantizado bastante difundido na umbanda.

E, ao que parece, essa especulação reverbera quando nos debruçamos sobre a manifestação da entidade caboclo nos rituais de umbandaime. Diferente do caboclo umbandista registrado na bibliografia, o caboclo do umbandaime não utiliza adereços plumários, não fuma charutos e não bebe nenhuma bebida alcóolica, além de possuir uma linguagem corporal distinta do arquétipo umbandista. Temos como exemplo o Mestre Ladislau, entidade que Jorge recebe e que não se encaixa em nenhuma categoria da umbanda. Mestre Irineu e Padrinho Sebastião também são alheios a qualquer categoria preexistente da parte de quem os recebe.

Padrinho Sebastião foi o responsável pelo desenvolvimento dos estudos umbandistas dentro da doutrina do santo daime. Foi através de seu aparelho ${ }^{41}$ que Ogum Beira-mar doutrinou o Exu Tranca-rua, que passou a beber daime e se tornou o guardião da doutrina e das igrejas do santo daime (Marques Junior, 2007).

O dia em que padrinho Sebastião fez sua passagem, ou seja, veio a falecer, coincidiu com o dia de São Sebastião logo após a realização da festa em homenagem ao

\footnotetext{
${ }^{41}$ Aparelho na concepção tanto do santo daime quanto da umbanda, é uma das formas de se referir ao membro da religião que recebe entidades em seu corpo físico, incorporando-as. Cavalo, aparelho e médium são sinônimos.
} 
santo. O fato de padrinho Sebastião ter de certa forma democratizado o santo daime, ou seja, levado a doutrina e a bebida sacramental a regiões muito distantes da floresta amazônica, contribuiu, entre outras coisas, para a consolidação de sua atribuição como um mensageiro da cura.

O Padrinho partiu exatamente na hora em que eram encerrados os trabalhos do dia de São Sebastião, na Igreja Rainha do Mar, diante das águas de Iemanjá, ao som dos violões e dos hinos do Santo daime e, ao longe, o dos atabaques de Umbanda e dos fogos de artifício que os devotos de São Sebastião ofereciam ao seu Padroeiro e seus Caboclos. (Marques Junior, 2007)

Mestre Irineu, ou Juramidam, e o padrinho Sebastião são considerados mestres curadores na doutrina do santo daime. Essa concepção de cura possui uma analogia estrutural com a concepção de cura umbandista que prescreve remédios através da mobilização do conhecimento de ervas, folhas e raízes. Esse imaginário da cura advinda dos conhecimentos da floresta está arraigado ao imaginário tanto do santo daime como da umbanda.

O daime, a bebida sacramental, carrega consigo essa essência de uma cura advinda da floresta, sendo inclusive indicada para diversos males do corpo e do espírito. Dentro da umbanda, se faz necessário encontrar um lugar no sistema simbólico que faça o diálogo com essa estrutura.

O que possibilitou a aproximação entre o orixá Oxóssi, habilidoso caçador com seu arco e flecha, e o santo católico São Sebastião, que possui flechas encravadas em seu corpo, possui como uma das respostas possíveis o fato de dois sistemas distintos terem encontrado no diálogo uma ponte de significado entre o orixá e o santo católico através da flecha. Essa mesma ambição pela aproximação estrutural através de elementos que falam, ao mesmo tempo, para lugares distintos, também pode ser verificada na aproximação realizada entre Padrinho Sebastião e os caboclos umbandistas que por correspondência também estabeleceria relação com Oxóssi e São Sebastião.

O elemento que possibilitaria a ponte de significado entre o sistema umbandista e o sistema daimista residiria sobre o fato de Padrinho Sebastião ser um reconhecido curador e, sobretudo, por curar e ser o difusor de uma bebida da floresta 
através da expansão do sistema religioso do santo daime. Nesse ponto o caboclo ribeirinho se mescla ao caboclo umbandista. Nos dois casos temos o profundo conhecimento na utilização das medicinas da floresta como uma das pontes de significado privilegiadas em que os dois sistemas religiosos encontraram para estabelecer diálogo.

Ele vem do alto

Destas matas brasileiras

É o caboclo

Pena-verde

Que vem aqui se apresentar

É o caboclo

Pena-verde

Que vem aqui para trabalhar

Ele vem balançando

Ele vem chacoalhando

$\mathrm{Na}$ força de cura de Juramidam ${ }^{42}$

Os conhecedores das curas e remédios da floresta no sistema daimista são, além dos comandantes espirituais reconhecidos como afamados curadores, os caboclos e os pretos-velhos. Dessa forma, é possível verificar uma analogia estrutural latente entre os dois sistemas religiosos em que transparece um ethos da floresta, como é evidenciado no ponto transcrito acima.

Uma analogia estrutural também é verificada entre a posição ocupada por Exu nas religiões afro-brasileiras e na doutrina daimista. Após a doutrinação do Exu Trancarua, este torna-se o guardião das igrejas, possuindo em muitos centros daimistas um ponto firmado à esquerda da porteira.

Sua presença nos cantos de abertura das giras com daime também reforça esse diálogo com o sistema afro-brasileiro. Exu representa no umbandaime uma entidade que transitou entre os dois sistemas simbólicos com bastante dinamismo, pois troca a cachaça da umbanda pelo chá do santo daime.

\footnotetext{
42 Ponto Caboclo Pena-Verde, de autoria de Nayana.
} 


\section{Capítulo III - O transe entre mundos}

\section{As interpretações acerca do transe nas religiões afro-brasileiras: breve panorama}

Passarei então, de agora em diante, a tratar do fenômeno do transe religioso que, sem dúvida alguma, é uma das manifestações considerada como pilar dos rituais que compõem este estudo, posto que, os frequentadores buscam nesses rituais justamente diferentes estados de transe que, como será discutido, podem assumir diferentes modalidades. Inicialmente, pretende-se apresentar brevemente a forma como esse fenômeno do transe tem sido abordado pela antropologia das religiões afro brasileiras ${ }^{43}$ e ayahuasqueiras. Posteriormente, a apresentação do que é entendido como transe pelo grupo e no que consistem tais manifestações para então buscar-se elementos que permitam a comparação da experiência do transe nas giras de umbanda com daime com diferentes análises e experiências de outras etnografias do campo religioso.

Faz-se necessário, porém, uma rápida delimitação do fenômeno que a literatura antropológica tratou como transe, possessão ou êxtase e, a partir dessas noções, inúmeras variações e combinações entre esses termos na tentativa de se construir durante muito tempo uma verdadeira taxonomia dessas experiências. Salvo raras exceções, tais tentativas reverberam quando confrontadas com o que é vivido pelos praticantes das religiões cotidianamente.

Entre os adeptos dos rituais que articulam os sistemas do santo daime e da umbanda é bastante raro ouvir o termo transe para definir suas experiências. As categorias utilizadas pelos frequentadores para definir experiências que a literatura antropológica classificou de diferentes formas são, de forma mais usual, a miração e a incorporação ${ }^{44}$.

A nomenclatura e a abordagem desses fenômenos variaram consideravelmente

\footnotetext{
${ }^{43}$ Para um amplo e detalhado levantamento bibliográfico da temática do transe nas religiões afrobrasileiras ver Goldman (1984)

${ }^{44} \mathrm{O}$ fenômeno também recebe outras nomenclaturas como, por exemplo, receber, baixar ou descer o santo. Santo, nesse caso, pode também ser substituído por entidade, em uma forma também genérica, ou ainda, em formas mais específicas, pode ser enfatizada a linha ou o próprio nome da entidade ou do espírito que se manifesta.
} 
nos estudos afro-brasileiros desde os estudos pioneiros de Nina Rodrigues, representando um paradigma médico na análise do fenômeno do êxtase religioso nos cultos afro-brasileiros. A abordagem feita pelo autor lança mão de uma linguagem retirada da psiquiatria para analisar e classificar as manifestações consideradas patológicas e derivadas, sobretudo de crises histéricas. Segundo Nina Rodrigues, os negros estariam mais sujeitos ao fenômeno da possessão, pois, na esfera individual, a manifestação da histeria estaria em relação ao fraco desenvolvimento mental do grupo enquanto raça que, associado aos impulsos sociais do meio, definiriam a forma que essa manifestação patológica assumiria.

Esses distúrbios mentais estariam relacionados a diferentes elementos que estariam presentes no ritual e contribuiriam para o afloramento dessa patologia como, por exemplo, a dança, a música, a ingestão de substâncias alucinógenas entre outros. $\mathrm{O}$ autor buscaria, dessa forma, explicações para dar conta do fenômeno do êxtase em áreas como a psiquiatria, biologia e a antropologia recorrendo em grande parte de sua análise em um reducionismo psicobiológico do fenômeno. Esse caminho explicativo, mais tarde também trilhado por Arthur Ramos, dedicou-se a compor e classificar o fenômeno da possessão através de certas variantes patológicas advindas do léxico das perturbações mentais.

Esses dois autores contribuíram para a instauração de uma corrente teórica que enxergava na possessão apenas a vestimenta cultural fornecida pelo contexto social que visava conduzir um fenômeno psicobiológico. A delimitação desse campo teórico e a abordagem proposta por esses dois autores exerceu durante muito tempo uma influência que Goldman (1984) classificou como locus clássico no estudo das religiões afrobrasileiras. Esse locus, como veremos, persiste parcialmente em muitos estudos contemporâneos, não só das religiões afro-brasileiras, mas também no campo das religiões ayahuasqueiras onde, de certa forma, adota-se muitas vezes um viés teórico apoiado no protagonismo psicobiológico do daime.

Uma grande ruptura em relação a esse modelo explicativo ocorre na década de 1950 com os estudos de Roger Bastide que, ao contrário dos dois autores citados anteriormente, propõe uma abordagem das religiões afro-brasileiras que se baseia em seu aspecto de realidade vivida, inseridas em uma sociedade brasileira envolvente. Bastide considera em sua análise da integração das religiões africanas a realidade 
brasileira o que ele denomina "princípio de corte". Segundo o autor, nas sociedades africanas a vida religiosa ou a "superestrutura" que continha os valores culturais estaria extremamente arraigada à morfologia social. Haveria, portanto confrarias de iniciados e sacerdotes que realizariam atividades religiosas que visassem o benefício do grupo como um todo, além de existir, em alguns casos, divindades consideradas antepassados de clãs e grupos familiares que, por sua vez, seriam responsáveis por render-lhes culto.

A escravidão surge então como uma violenta e avassaladora destruição das estruturas familiares, mas que aparentemente não possuiu o mesmo efeito sobre os valores culturais que, entre outras coisas, apesar do abismo instaurado entre estrutura e superestrutura se manteve e, de certa forma, orientou a construção de uma nova base social através das comunidades religiosas. Esses grupos de culto instaurados no Brasil seriam vividos por seus adeptos como plenamente separados da sociedade inclusiva, o que possibilitaria que os membros do Candomblé vivessem a vida religiosa completamente separada da vida cotidiana, separação essa que representaria o que Bastide chamou de "princípio de corte".

A exemplo do que ocorreria na África, essas religiões, e sobretudo o êxtase religioso, poderiam ser entendidos na chave de uma mediação entre sagrado e profano que, no Brasil, seria acrescido de uma dimensão compensatória em relação às baixas posições sociais ocupadas pelos adeptos, que seriam "compensados" ao atuarem como divindades místicas em contraposição aos seus papéis sociais assumidos na vida cotidiana. O ritual extático seria então um ritual-experiência-vivida e a possessão, não uma simples substituição, mas uma verdadeira metamorfose da personalidade. Essa mudança de perspectiva representou uma ruptura em relação à abordagem psicobiológica anterior, colocando em cena uma interpretação da possessão como fato social que deveria, portanto, ser explicada em relação ao contexto sociológico e não através da importação de conceitos da psicopatologia individual (Goldman, 1984).

Se de um lado encontramos esse abismo entre o enfoque teórico de Bastide e as abordagens evolucionistas e psiquiátricas, por outro e, sobretudo com relação ao tratamento dedicado à umbanda, vemos uma relativa aproximação com as teorias clássicas. Essa aproximação torna-se evidente quando Bastide se apoia em Arthur Ramos para comparar o transe na umbanda carioca e no candomblé baiano, este último tido como um processo relativamente calmo e controlado pelo grupo, contrastando com 
uma tendência a histeria existente na umbanda carioca. $\mathrm{O}$ autor aparentemente entende que essa tendência seria compreensível, pois os médiuns não teriam uma mitologia para regrar o transe e fazer dele uma imitação dos gestos divinos, o que levaria os indivíduos a uma gesticulação apaixonada, fruto da desorganização interior provocada pela passagem do estado normal para o segundo estado (Bastide, 1960 pp. 409).

O trabalho de Camargo (1961) representa certa continuidade em relação a abordagem do período anterior onde predominaram as abordagens funcionalistas e culturalistas de notável influência sociológica, mas também uma notável ruptura, pois é a partir da década de 1960 que o enfoque dos estudos nos cultos tidos como mais puros perde força e surge então uma nova ênfase nos cultos tidos como mais sincréticos. Uma das maiores contribuições de Camargo para os estudos afro brasileiros foi a perspectiva assumida em relação à umbanda e ao kardecismo que passou a considerá-los como diferentes polos pertencentes a um mesmo espectro religioso havendo, todavia, entre esses dois polos, uma infinidade de variantes que pertenceriam ao que ele denominou de continuum mediúnico (Camargo, 1961).

Camargo adota também uma abordagem teórica do transe na umbanda que representa uma ruptura, ou melhor, uma inversão na forma como ele vinha sendo tratado por grande parte dos autores até o momento. $\mathrm{O}$ autor estabelece a relação entre "mediunidade mais ou menos consciente" e "desenvolvimento do aparelho" afirmando que, dependendo da posição que o médium ocupa nesse espectro, ocorrem modificações na voz, nos gestos e nas atitudes. A mediunidade consciente representa para o autor uma estreita ligação com a tradição Kardecista, e seria recorrente em todo o continuum até o polo oposto, no caso a umbanda. O conceito é traduzido como a capacidade do médium em "perceber a entidade que recebe e exercer sobre a mensagem transmitida um relativo controle emocional, lógico e ético" (Camargo, 1961, p. 20).

O trabalho de Concone (1987) sobre a umbanda ${ }^{45}$ possui uma longa discussão sobre a forma como o transe foi tratado pela antropologia que, a partir das diferentes tentativas de sistematização e definição do fenômeno, leva a autora a propor uma nova nomenclatura. Após demonstrar a maneira como diferentes autores definiram os conceitos de êxtase, possessão e transe, a autora constrói seu arcabouço conceitual que

\footnotetext{
${ }^{45}$ Trabalho apresentado originalmente como Tese de Doutorado à PUC/SP no ano de 1973.
} 
identifica no transe um estado alterado de consciência, seja ele total ou parcial, e passa a definir a possessão como uma explicação culturalmente atribuída a estados de transe ou não. No caso específico da umbanda, onde a crença na possessão estaria apoiada em alterações comportamentais, sensórias, perceptivas e mnemônicas evidentes, a possessão apareceria ligada ao transe, o que justificaria a adoção da nomenclatura "transe de possessão" (Concone, 1987 pp.102).

Apoiada sobretudo em categorizações de Lewis para a classificação do transe, a autora identifica a existência, na umbanda, de um transe "controlado" e outro "não controlado", que Bourguignon definiu como "positivo" e "negativo", respectivamente. $\mathrm{O}$ que se pretende destacar aqui é a constatação feita pela autora de que "mesmo o transe "controlado" ou "positivo" teria partido sempre de uma situação "não controlada", em maior ou menor grau”. (Concone, 1987 pp.101) A constatação de que o transe de possessão é um papel aprendido, formalmente ou não e, portanto, seu maior controle está diretamente relacionado ao aprendizado e à prática, levou a autora a concluir, provavelmente com base em sua verificação empírica, que "nas cerimônias afro-brasileiras o médium mais experiente é o que assume o transe mais rapidamente" (Concone, 1987 pp.101).

A mediunidade, segundo a autora, pode ainda ser dividida em três categorias de médiuns, de acordo com seus informantes. Existiria, segundo ela, o médium inconsciente, que entraria em estado de "transe total", e o médium consciente, que seria possuído sem o transe. Ela acrescentaria ainda uma terceira categoria, a de médium vidente e ouvinte, ou seja, aquele que não recebe o santo, mas pode vê-lo e falar com ele existindo sempre a ressalva de que em muitos momentos o médium também pode incorporá-lo. Essa experiência mediúnica é denominada pela autora como aparelhamento, que etimologicamente seria uma corruptela de emparelha, ou seja, estar próximo de algo, mas que poderia também se referir a "criar condições" para que o espírito se manifeste (Concone, 1987 pp. 120).

Contudo, ademais das categorizações, a autora chama a atenção para o fato de que o transe de possessão mediúnico mais comum para os umbandistas é aquele em que o médium não está inteiramente consciente e tampouco inconsciente, situando-se em uma “posição intermediária" entre esses dois polos (Concone, 1987 pp. 120). O transe de possessão pode ser entendido na chave de um processo que pode, e deve ser 
aprendido pelo médium. Essa interpretação é possível a partir da observação feita pela autora de que existiria um transe mais "violento" e um processo de incorporação e desincorporação mais demorado nos "médiuns novos". Isso se daria em contraposição ao transe de possessão dos médiuns mais experientes, considerado como uma "passagem natural" pela autora, ou seja, não seria possível notar o momento exato da incorporação (Concone, 1987, pp.126).

Outro importante trabalho que abordou a umbanda foi realizado por Ortiz (1991) que, apesar do transe possuir um aspecto secundário em sua obra, o fenômeno é analisado pontualmente, quase sempre de forma comparativa ao candomblé. $\mathrm{O}$ autor enxergava no transe do candomblé a repetição dos mitos, as aventuras e desventuras dos deuses, que na umbanda desapareceriam completamente. Segundo ele, as divindades negras não desceriam mais para dançar com os homens, em contrapartida, essas seriam substituídas por espíritos que cavalgariam o corpo dos médiuns. Aos deuses, na visão do autor, restaria apenas o papel de evocar o nome das diferentes linhagens nas quais os espíritos estariam divididos (Ortiz, 1991 pp.70).

Essa constatação, segundo Ortiz, implica em algumas consequências no comportamento mediúnico. O autor trabalha com a ideia de que os "esquemas motores", entendidos como significantes, da umbanda seriam muito genéricos, pois ao tratar de grupos de entidades o sistema os submeteria a categorias atribuídas vagamente. $\mathrm{O}$ exemplo utilizado pelo autor repousa no fato de se atribuir a ideia de força aos caboclos; a humildade aos pretos-velhos e a inocência às crianças. A ausência de uma trama mítica para articular os modos de possessão deixaria os significantes à disposição de qualquer significado. Isso, segundo o autor, conferiria à possessão uma parcela considerável de individualização, ao contrário do que aconteceria no candomblé em relação ao transe dos deuses africanos. Dessa forma, a personalidade das entidades na umbanda seria uma personalidade vazia, ou seja, nomes como Caboclo Roxo ou Pai Joaquim D'Angola representariam apenas uma "massa anônima de índios e negros que participaram da formação da sociedade brasileira" (Ortiz, 1991 pp.77).

Essa relativa indeterminação do modelo religioso cederia espaço a individualidade do adepto, recaindo sobre a personalidade do médium a definição da personalidade da entidade espiritual que ele encarna. $\mathrm{O}$ autor conclui que a partir de uma despersonalização do cosmo, mais precisamente a passagem de deuses 
individualizados para espíritos indeterminados, ocorreria concomitantemente uma personalização do transe, mais adaptada a uma sociedade onde o indivíduo é bastante valorizado. Dessa perspectiva adotada pelo autor, a umbanda estaria a meio caminho entre o transe mais próximo de uma "individualização total", manifestado no espiritismo de Allan Kardec, e uma medida menor de individualização encontrada dos cultos afro-brasileiros como o candomblé (Ortiz, 1991 pp. 77).

O campo de estudos sobre o transe religioso afro-brasileiro foi dividido, segundo a análise de Goldman (1984), em dois caminhos interpretativos. O primeiro deles, classificado pelo autor como "biopsicológico", tinha como característica teórica a busca de respostas para o fenômeno no campo médico, seja considerando as manifestações como doenças mentais ou encontrando no transe uma forma de terapia mais ou menos satisfatória para controlar essas doenças.

O outro caminho pode ser caracterizado como "sociopolítico", justamente por encontrar no transe uma manifestação ou até mesmo um mero reflexo da organização social envolvente, seja reforçando esse modelo ou invertendo-o. Tanto nas explicações biopsicológicas como nos modelos sociopolíticos, a argumentação do autor encontra um reducionismo do fenômeno em esferas explicativas que lhe são alheias, contrariando um pressuposto elementar da própria antropologia. A explicação, ou ao menos o fio condutor que pode levar a uma interpretação do fenômeno, repousa sobre o “desvendamento da estrutura lógica a eles subjacente" (Goldman, 1984).

O autor procura atingir seu objetivo através da investigação da noção de pessoa do grupo em questão, considerada intrinsecamente relacionada à manifestação do fenômeno da possessão. Em outras palavras, para compreendermos o transe é necessário antes compreender a construção da pessoa envolvida, algo que só pode ser realizado através de uma teoria da noção de pessoa do grupo em questão. O pressuposto de que existe uma coincidência sobreposta com exatidão entre indivíduo biológico e a noção de pessoa foi justamente o que levou, de forma implícita, muitos antropólogos a suporem que a noção ritual de pessoa seria uma espécie de máscara que estaria de certa forma ligada a compensações para o indivíduo advindo da sociedade abrangente (idem).

A noção de pessoa no candomblé envolve em sua construção uma síntese de elementos materiais e imateriais o que significa que para falarmos de um ser humano temos que necessariamente falar sobre o corpo (ara), o Ori, os orixás, o Erê, o Egum e o 
Exu. Todos esses elementos fazem parte da composição de todos os seres humanos e permaneceriam latentes até sua fixação dada pelos ritos iniciáticos. Tal processo só estaria completo, ou seja, a rigor só poderíamos falar em uma pessoa plena, passados 21 anos desde sua iniciação (idem).

Após esse período ocorre uma possível suspensão do transe, finalizando, de certa forma, um longo processo caracterizado pela redução da frequência e da intensidade da possessão desde a primeira experiência que seria a "bolação". Nesse momento o adepto é considerado "senhor de si", pois já é capaz de controlar os elementos que constituem a sua pessoa, o que proporcionaria uma estabilidade mais duradoura. A possessão teria então um papel na vida religiosa do adepto que seria o de aproximação entre o não ser da pessoa em construção e o ser pleno dos orixás, tendo em vista que é impossível para um ser humano tornar-se orixá, o mais próximo desse ser pleno a que se pode chegar é atingindo-se a categoria de Tata, após 21 anos de iniciado, quando então a possessão tenderia a cessar e a pessoa ritual passa a exercer seu controle sobre os próprios orixás (Goldman, 1984).

\section{Breve panorama sobre a abordagem do transe nas religiões ayahuasqueiras}

Aparentemente a discussão sobre o transe na bibliografia sobre as chamadas "religiões ayahuasqueiras", com destaque para o santo daime e para a barquinha, é bastante diversificada e nosso esforço no presente momento será na direção de identificar alguns movimentos distintos dentro dessa produção que, longe de ser tão vasta quanto das religiões afro-brasileiras, constitui-se enquanto campo de investigação relativamente recente da antropologia cujos primeiros trabalhos surgiram no início da década de 1980.

Dentre esses trabalhos pioneiros, dedicarei mais tempo àqueles que abordaram o transe de forma mais sistemática, como é o caso de Fernando de La Roque Couto (1989), que em sua dissertação de mestrado "Santos e Xamãs", argumenta sobre a utilização ritual da ayahuasca por caboclos da Amazônia, sobretudo voltado para a dimensão socioterapêutica da bebida dentro da doutrina do Santo Daime. O que se 
pretende ressaltar desse trabalho é o fato dele apresentar de forma pioneira uma análise do transe ritual no sistema religioso do Santo Daime, classificada pelo autor como "xamanismo coletivo".

O conceito de xamanismo coletivo cunhado pelo autor é apoiado, sobretudo em definições do xamanismo siberiano trabalhadas por Lewis (1971 apud La Roque Couto, 2002) e Eliade (1960 apud La Roque Couto, 2002) que enxergam nas práticas xamânicas dos povos da Sibéria, de acordo com La Roque Couto (2002), duas abordagens distintas para o fenômeno. Esses "dois lados do mesmo fenômeno" são representados, segundo o autor, por dois tipos diferentes de xamã, o viajante e o possesso (Baldus, 1965 apud La Roque Couto, 2002).

A principal argumentação do autor, que se afasta da concepção de xamanismo entendido por outros autores citados por ele como, por exemplo, Mircea Eliade (1998), repousa no fato de que no sistema religioso do Santo Daime todos os membros seriam xamãs potenciais. Ele aproximaria ainda a categoria de xamã viajante aos "voos astrais" realizados pelos adeptos do Santo Daime onde, segundo o autor, o espírito se separaria do corpo e viajaria pelo astral. O xamã possesso seria verificável nas experiências em que os membros serviriam como aparelhos para a recepção de seres.

O autor chegaria dessa forma a uma definição do xamã como um "especialista do trânsito entre o aqui e o lá, entre o corpo e o espírito". Esse transito seria definido como semelhante a uma viagem, onde haveria uma "ascensão a planos de harmonia e compreensão" que seriam também classificados como um "mundo simbólico povoado por entidades espirituais". Essas entidades por sua vez também seriam capazes de empreender uma viagem semelhante à viagem do xamã, porém cujo resultado seria a possessão (La Roque Coutro, 2002, p. 405).

Eventualmente pode-se questionar sobre o rendimento do conceito de xamanismo para caracterizar experiências religiosas que apresentam apenas uma semelhança superficial às atividades e atribuições de um xamã siberiano. O conceito de xamanismo quando utilizado como pressuposto autoexplicativo de fenômenos dessa ordem, prática essa bastante difundida entre os estudos do campo das religiões ayahuasqueiras, não fornece uma delimitação precisa do fenômeno e tampouco uma crítica teórica do conceito produzindo, dessa forma, uma contribuição teórica questionável para o estudo da incorporação e da miração. Faz-se necessário uma 
abordagem que adote uma perspectiva crítica sobre a própria viabilidade teórica de uma noção como a de xamanismo, amplamente difundida dentro e fora da academia e que congrega as mais variadas e díspares experiências, da Sibéria às religiões new-age das grandes metrópoles.

As próprias interpretações do xamanismo siberiano nas quais o autor se apoia são questionáveis, sobretudo por possuírem como ponto de partida uma cisão da pessoa do xamã expressa pelo par corpo e espírito. Essa dicotomia quando utilizada como pressuposto intrínseco nas interpretações e análises da incorporação e da miração, na umbanda e no santo daime, respectivamente, produz uma distorção desses fenômenos que acaba por colocar em xeque questões fundamentais relativas à cosmologia desses grupos.

É bastante significativo quando um frequentador do santo daime ao relatar sua experiência de miração enfatize o fato de que ele estava presente em determinado local e em determinada situação, formulações como "eu estava lá" também são notadas por Mercante (2012) e consideradas bastante recorrentes na Barquinha. Nesses relatos de miração, os frequentadores não costumam fazer menção a uma cisão entre o que seria seu corpo e o seu espírito, pois muito provavelmente essa cisão não faça o menor sentido e o estar presente nesses casos está justamente demonstrando uma concepção diferente de corpo envolvida na experiência.

Com relação a incorporação, é bastante recorrente na religião umbandista, conforme demonstrado anteriormente, uma notada recorrência das experiências que ficam a meio caminho entre o que o grupo define como consciência e inconsciência. $\mathrm{O}$ fato de serem menos recorrentes as experiências exclusivamente conscientes ou inconscientes e, talvez até mesmo ocorrendo raramente na prática, faz-se questionável concepções de "possessão" que considerem o corpo como um receptáculo, cindido do próprio espírito, que espera ser preenchido por uma entidade. De acordo com relatos de frequentadores da umbanda que passaram a participar de rituais com daime, essa dicotomia não faz muito sentido, pois as experiências de incorporação representam para esse grupo um complexo diálogo entre a pessoa e a entidade. As próprias entidades são constitutivas da noção de pessoa do grupo, sendo comum a identificação de determinada entidade com uma pessoa dizendo-se; o caboclo de alguém ou o preto-velho de outrem. Dessa forma, pretende-se mostrar que uma experiência de incorporação não remete a 
passividade de um corpo que é animado por outrem, mas, ao invés disso, trata-se de um processo de construção da pessoa que demanda necessariamente, de acordo com o grupo, um controle da experiência.

O antropólogo Clodomir Monteiro da Silva, apesar de ser considerado o pioneiro no estudo do santo daime não possui, em seu trabalho inaugural, o transe como foco principal de seus esforços. Contudo a temática foi abordada posteriormente pelo autor em um artigo publicado na coletânea organizada por Labate e Araújo (2002). Deste artigo cabe destacar a utilização da categoria irradiação, também utilizada pelo grupo daimista, e a articulação dessa experiência com as mirações, porém fica difícil avançar nesse sentido, pois as definições do autor a respeito dos dois fenômenos não são precisas. Na conclusão do artigo o autor chega a uma definição mais precisa sobre irradiação, que considera ser um "estágio do processo de incorporação, que se situaria entre esta e a miração enquanto trabalho no Astral" (Monteiro da Silva, 2002).

O autor aborda de forma rápida os "transes extáticos" na barquinha, uma das três religiões ayahuasqueiras brasileiras mais antigas, afirma que neste grupo poderiam ocorrer simultaneamente experiências de miração e de incorporação. A interpretação acerca da possessão leva em conta, em outra passagem, o fenômeno em questão como uma experiência inconsciente. No entanto, o autor parece considerar a miração como uma categoria abrangente do transe dentro da qual se acomodariam de alguma forma subdivisões como a possessão, a visão mística, a irradiação e o voo xamânico. A miração seria considerada enquanto "categoria inscrita como um dos estados alterados de consciência, interno ao corpo, desdobrando-se em ordens de realidades totais que são construídas e desconstruídas em dialogias com o físico, o químico, o biológico..." (Monteiro da Silva, 2002).

O antropólogo Edward MacRae, já no início dos anos 90, foi quem dedicou maior atenção ao estudo do transe no santo daime. A temática surge em seu trabalho Guiado pela Lua (MacRae, 1992) e adquiri posteriormente um corpus mais definido, sobretudo em seu livro El Santo Daime y la espiritualidade brasileña (MacRae, 2000). $\mathrm{Na}$ perspectiva assumida pelo autor, a religião daimista ocuparia uma posição mais próxima ao polo kardecista a partir da adoção da noção de continuum mediúnico utilizada por Camargo (1961) para o campo das religiões ayahuasqueiras.

Para o autor, na investigação do continuum existente entre kardecismo e 
umbanda, a determinação do que está mais próximo ao polo kardecista seria mais fácil, pois esse polo seria melhor codificado em relação a umbanda, essa última dotada de características como um "sincretismo dinâmico em fase de consolidação, de transmissão oral e com dificuldades em estabelecer estruturas institucionais de maior amplitude" (MacRae, 2000, p.68).

$\mathrm{O}$ autor indica uma nova continuidade, porém dessa vez entre os cultos africanos considerados mais puros, como o candomblé da Bahia e o tambor de mina do Maranhão, e os cultos considerados mistos. Esses últimos com marcada influência indígena que, de certa forma, remeteria a antigas práticas de pajés que recebiam espíritos guias para atenderem seus consulentes. As experiências de transe que ocorrem mais próximas ao polo africano são consideradas mais estilizadas e altamente controladas, seja pela tradição, seja pelo líder da cerimônia. Os cultos mistos por sua vez seriam caracterizados pelo fato do médium poder receber inúmeros espíritos guias e, mais especificamente na "pajelança ayahuasquera", ocorreria outro tipo de transe, o "vuelo shamánico", onde ao invés de ceder seu corpo para a atuação de outras entidades espirituais o indivíduo realizaria viagens ao mundo dos espíritos com interações que afetariam a vida do indivíduo e de seus clientes (MacRae, 2000, p. 74).

A pesquisa bibliográfica realizada pelo autor sobre o fenômeno da pajelança amazônica evidencia uma relativa cisão entre essas duas modalidades de transe nos modelos explicativos adotados pelos estudiosos do tema. Uma das hipóteses levantas pelo autor aponta para o fato desse parti pris ser um reflexo não apenas do próprio investigador, mas também, em parte, do próprio objeto de estudo. Situações vividas em campo pelo autor reforçariam essa hipótese, em que adeptos do voo xamânico criticaram episódios de possessão principalmente devido à exposição demasiada a que o médium estaria sujeito, correndo o sério risco de ser incorporado por espíritos inferiores.

Nesse mesmo capítulo o autor define o que entende por "estado alterado de consciência" através de uma série de características que podem ser verificadas em uma grande diversidade de situações e conclui que, apesar das diferenças, os "estados alterados de consciência" produzidos na umbanda e no santo daime fazem parte do mesmo continuиm. Esses estados tendem, segundo o autor, a confirmar as crenças e os valores do grupo e, portanto, existiria a intenção de se restringir a alteração da 
consciência tanto na umbanda quanto no santo daime a contextos cerimoniais. Evitando-se, dessa forma, através de uma série de prescrições, consequências indesejadas ao indivíduo que sofre o transe (MacRae, 2000, p.77-83).

O estudo comparativo do transe é desafiador ao ponto de fornecer fôlego para uma pesquisa dedicada exclusivamente a essa temática. Porém nesse momento cabe apenas alguns comentários a respeito da forma como esse fenômeno foi abordado no estudo das religiões ayahuasqueiras. Ao buscarmos uma unidade comparativa para o transe somos tentados a projetar sobre o objeto de nosso estudo nossas próprias impressões acerca do fenômeno e da pessoa envolvida na manifestação. Conforme demonstrou Goldman (1984) em seu estudo sobre o transe nas religiões afro-brasileiras, a pessoa do candomblé não coincide necessariamente com o indivíduo pensado na sociedade envolvente. A noção de pessoa varia, dessa forma, dependendo do grupo religioso que tomamos como referência. O trabalho pioneiro de Marcel Mauss (2003) demonstrou brilhantemente como a noção de indivíduo foi cunhada na sociedade ocidental ao longo dos tempos e, dessa forma, se constituindo como uma particularidade dessa, não condizendo, portanto, com uma categoria que possa ser tomada para abordagem de outros povos e grupos sociais. Dedicar-se ao estudo grupos religiosos como o santo daime e a umbanda implica na necessidade de se compreender primeiramente qual é a noção de pessoa adotada por esses grupos e, em um segundo momento, se existe algum sentido compará-las para, posteriormente, procurar quais seriam os critérios dessa comparação.

Ao admitir-se categorias como "voo xamânico", "possessão" e até mesmo o transe como um "estado alterado de consciência", conceitos adotados em larga escala por pesquisadores das religiões ayahuasqueiras até o final da década de 1990, parte-se implicitamente do pressuposto de que a base dessa comparação recai sobre uma unidade que, longe de levar em conta as noções de pessoa envolvidas em cada grupo, projeta apressadamente uma cisão entre corpo e espírito ou ainda entre corpo e consciência que se desdobra em explicações apoiadas em categorias que limitam o ganho teórico por se distanciarem da complexidade da noção de pessoa desses grupos.

A questão fundamental aqui é indagar-se sobre o quanto renderia do ponto de vista teórico uma comparação entre a pajelança indígena, a mirarão de um adepto de uma religião ayahuasqueira e a incorporarão de um frequentador da umbanda através do 
pressuposto de que em todos esses casos estaríamos diante de fenômenos de "estados alterados de consciência" que abarcaria experiências como o "voo xamânico" e a "possessão" do corpo por uma entidade, ou ainda, reformulando a questão de outra maneira, não seriam as próprias noções adotadas de consciência, corpo e espírito, unidades equivocadas para realizar essa comparação justamente por serem demasiado naturalizadas e por isso demandarem uma reflexão crítica cuidadosa?

Guimarães (1992) em seu estudo pioneiro sobre os diálogos entre santo daime e umbanda através do estudo de caso de um terreiro de umbanda no Rio de Janeiro possui uma abordagem sobre a incorporação em que considera essa situação como uma oportunidade que o indivíduo possui para vivenciar aspectos múltiplos e muitas vezes contraditórios de sua identidade pessoal. A autora chega a essa conclusão apoiando-se em parte na análise de Monteiro (1985 apud Guimarães, 1992) que considera que "todo indivíduo tem, e é ao mesmo tempo, seu caboclo, seu preto-velho, sua criança e seu exu” Monteiro (1985 apud Guimarães, 1992, p.150).

Essa individualização sugere, segundo a autora, que em contextos onde existiria apenas uma aparente desindividualização, como seria o caso da incorporação, existiriam instâncias individualizadoras operando em diferentes níveis. De acordo com as concepções do grupo estudado, Guimarães (1992) sugere a existência de dois tipos de incorporação, uma involuntária, que se subdividiria em obsessão e incorporações descontroladas provocadas por espíritos inferiores, e a segunda possibilidade que seria uma forma voluntária, em que o controle da experiência seria aliado ao fato do espírito incorporado já ser conhecido pelo médium. Seguindo o raciocínio da autora, pode-se concluir que uma incorporação controlada seria aquela em que a entidade se encontra individualizada em relação ao médium que a recebe, o que se torna ainda mais claro pelo fato dessa entidade já possuir, a essa altura, um nome próprio.

A dicotomia utilizada pela autora entre miração e incorporação caracterizando, respectivamente, a forma do transe no santo daime e na umbanda, estaria intimamente relacionada às diferentes concepções de mundo de cada um deles. No santo daime, segundo a autora, o mundo dos homens é uma ilusão e o mundo real e verdadeiro seria o mundo dos espíritos que seria acessado pela miração. Essa concepção daimista, de certa forma, implicaria no fato das incorporações não serem, via de regra, estimuladas pelo grupo, com exceção aos trabalhos de Estrela onde os participantes dariam 
passagem aos espíritos como forma de se exercer a caridade. A umbanda possuiria uma perspectiva diferente, pois a partir do mundo material ela buscaria demonstrar a existência de outros mundos astrais (Guimarães, 1992).

Posteriormente, a temática do transe volta a aparecer no trabalho de Marques Jr. (2007), porém, com o diferencial de possuir uma forte ênfase histórica em sua abordagem. Na perspectiva adotada pelo autor, o transe é tido como um dos elementos centrais no fenômeno de inserção da umbanda no santo daime. A extensa e esclarecedora pesquisa realizada pelo autor das matrizes religiosas e dos elementos fundantes da umbanda e do santo daime indica uma tentativa de se recuperar o cenário histórico de um período considerado fundante da lógica pela qual a aproximação entre santo daime e umbanda seria interpretada pelos seus integrantes (Marques Jr, 2007).

O autor, ao analisar o fenômeno do transe no kardecismo acaba por considerálo responsável, em certa medida, por informar a experiência de transe daimista que, através do paradigma da construção do sujeito em sua interioridade, se apoiaria na perspectiva de que seria esse mesmo sujeito, em última instância, o responsável por suas escolhas e por sua consequente graduação dentro da religião. (Marques Jr, 2007) Esse paradigma kardecista identificado pelo autor como uma das possíveis matrizes do fenômeno do transe no santo daime possibilitaria a "democratização do transe" (Goulart, 1996, apud Marques Jr., 2007) em um momento de transição das tradições vegetalista caracterizadas por um "xamanismo individual" para a forma do "xamanismo coletivo" recorrente no santo daime (Marques Jr., 2007), notadamente apoiado nos trabalhos de Monteiro (2002) e Couto (1989).

De forma semelhante a aproximação entre o kardecismo e o universo afrobrasileiro através da articulação da noção de mediunidade, o autor supõe que algo semelhante ocorra no culto do santo daime pois, aparentemente, haveria uma íntima relação entre a experiência obtida através da ingestão do chá que, aliada a noção de mediunidade, encontraria, de certa forma, reverberação na experiência umbandista. $\mathrm{O}$ kardecismo possuiria, de acordo com o autor, uma variedade de modelos de incorporação desde as mais mentais até aquelas consideradas inconscientes o que também, de certa forma, favoreceria sua receptividade no santo daime e que, posteriormente, se constituiria como um dos caminhos em que se daria a abertura para a umbanda (Marques Jr., 2007). 
Utilizando-se do conceito de gradiente mediúnico proposto por Camargo, o autor situa o santo daime, na ocasião de seu surgimento, mais próximo do polo "branco", pois identifica esforços para marcar-se um distanciamento entre a religião nascente e as religiões afro-brasileiras. Entre essas constatações é destacado o tratamento dado às entidades do panteão afro-brasileiro que, responsabilizadas pelas aflições dos adeptos, compunham os fenômenos passíveis de exorcismo. (Goulart, 1996, apud Marques Jr., 2007).

Sob uma perspectiva que foge à linha de desenvolvimento das abordagens do fenômeno do transe verificadas no campo de estudos das religiões ayahuasqueiras, Mercante (2012) propõe uma discussão sob o pano de fundo da interação entre consciência e matéria. Através do trabalho etnográfico realizado na Barquinha de Madrinha Chica ${ }^{46}$, em Rio Branco/AC, o autor aborda o fenômeno do transe da perspectiva de quem "experienciou" essa situação e a assumiu abertamente. A abordagem adotada estabelece o transe como peça fundamental para a construção da etnografia pois, para além da experiência individual, o autor realizou entrevistas com médiuns incorporados estabelecendo, dessa forma, seu acesso a cosmologia do grupo apoiado no fenômeno do transe.

O autor parte do conceito de miração definido como "imagem mental espontânea" para acessar concepções de doença e cura entre os participantes dos rituais do centro pesquisado. A definição de miração para o autor está ligada às experiências visionárias dos participantes durante o ritual, mas não se restringiria somente a elas, podendo envolver experiências sonoras, olfativas e gustativas. Seria, para, além disso, o momento em que os adeptos receberiam os ensinamentos dos seres espirituais. Receber, nesse caso, significa que a miração independe da vontade de cada participante para chegar até a pessoa que seria contemplada com essa experiência (Mercante, 2012).

$\mathrm{O}$ autor parte da premissa religiosa de que a dimensão espiritual ocupa um espaço que pode inclusive ser visitado pelos adeptos durante as mirações. A própria exploração desse espaço espiritual corresponderia ao desenvolvimento espiritual do participante. De acordo com a concepção nativa, o espaço físico, onde ocorreria a vida ordinária, seria o resultado da ação de inúmeras forças contidas no espaço espiritual, ou

\footnotetext{
${ }^{46}$ Fazer referência às diferentes barquinhas existentes em Rio Branco e à proximidade dessa religião com práticas mediúnicas características das religiões afro-brasileiras, mais especificamente a umbanda.
} 
seja, existiria a priori o espaço espiritual que se desdobraria em um espaço físico por meio de um regime de causalidade próprio (Mercante, 2012).

A incorporação seria a presença do outro mundo no indivíduo, seja através do axé de determinado orixá, de determinada entidade ou da própria Força. Para um filho de santo da umbanda, seu corpo é um canal de comunicação com o outro, um canal de manifestação do axé. A miração e a incorporação estariam, de certa forma, integradas e por isso mesmo deveriam ser pensadas em par, como se o balanço do pêndulo da experiência alternasse sua posição entre dois mundos, oscilando entre um movimento que permitiria que o outro mundo se manifestasse aqui através de uma força que lhe seria característica e, em um movimento complementar, possibilitaria que, durante as mirações, o próprio participante do ritual se manifeste nesse outro mundo denominado astral.

\section{A umbanda ensina abrir a porta, o daime abre - uma análise da experiência}

O discurso nativo sobre o transe religioso aponta para uma preocupação, às vezes mais ou menos evidente, que é da necessidade de contextualização das experiências dessa ordem. Conforme bem resumiu Gê Marques em entrevista:

.... Agora, ele[o transe] será tão mais benéfico, curador e equilibrado, quando o médium que experiência a incorporação também já consegue dominar a experiência com a alteração da força que o daime traz. E que possa incorporar sempre nos espaços adequados, assim como consegue ter um trabalho de contenção e viver a experiência do daime longe de incorporação nos outros trabalhos.

Ao mesmo tempo em que o transe é algo que precisa ser contextualizado através de um controle desenvolvido pelo médium, ele possui também uma dimensão que escapa, eventualmente, a qualquer tentativa de estabilização. O pai de santo Jorge Scritori evidencia essa dimensão arredia e volátil do transe quando afirma que ele “combate seu lado racional".

Outro ponto bastante recorrente nas falas dos adeptos, apesar das variadas nuances que essa questão possa assumir, é o fato de o transe ser considerado uma experiência transformadora. Madrinha Natalina define o transe como uma conversa com 
seus guias em que ela se encontra em um estado de dualidade sendo, em suas palavras, metade ela e metade não-ela.

Essa dualidade podia ser notada facilmente durante o ritual ou até mesmo em conversas realizadas após o ritual quando, sob influência da força, Madrinha Natalina tinha seu discurso atravessado por irrupções responsáveis por criar uma sequência não linear para a conversa. Essa aparentemente é a parte rompante dessa dualidade, mas de acordo com o discurso da mãe de santo existe uma parte da dualidade que não se externalizaria, no sentido de ser compreensível a outrem. Trata-se dessa conversa intimista com as entidades que envolvem o recebimento de recados e de instruções diretamente desses seres que povoam o cosmo, bem como a realização de perguntas e pedidos pela Madrinha a eles.

Os sacerdotes dos quatro centros que frequentei durante essa pesquisa também fizeram reflexões sobre a natureza do transe e das incorporações. Pai Dalmo, por exemplo, entende o transe como algo extensível a diferentes religiões e, mais ainda, à humanidade:

Eu acho que transe é tudo. Eu acho que o pessoal que está na igreja pentescostal Deus é amor conhece o transe. Quem está na Canção Nova da igreja carismática conhece o transe. É um dom que pode ser compartilhado por todas as pessoas...

Sua concepção de dom como algo que pode ser compartilhado por todas as pessoas se aproxima da própria concepção de Força, que é algo central para se compreender a dinâmica do transe e o próprio trânsito entre o Astral e o mundo ordinário. Da mesma forma que a concepção de dom, essa força existiria justamente para ser compartilhada nos dois sentidos que o termo pode assumir. Poderia, por exemplo, ser acessada pelas pessoas e, ao mesmo tempo, para ser acessada precisaria estar circunscrita dentro de uma experiência individual, ou seja, compartimentada. Essa Força de que nos falam os adeptos emana do Astral, que se constitui como um lugar distinto do mundo ordinário e, ao mesmo tempo, é a chave para acessá-lo.

Nos centros religiosos em que pude realizar esta pesquisa é notável o fato do termo Força aparecer de forma bastante recorrente nos discursos dos frequentadores que participam das sessões com daime. A Força, que em algumas oportunidades pude contemplar, trata-se de uma experiência extremamente complexa por tratar-se de um 
processo que envolve a presença simultânea de dois mundos e, consequentemente, isso a torna algo de difícil definição.

É possível, porém, uma abordagem sobre o seu papel central na comunicação com o plano astral. A Força, de certa forma, provém do próprio Astral e através do daime é transmitida aos médiuns que, ao mesmo tempo, precisam estar na força para efetivamente adentrar ao próprio Astral.

O conceito pode surgir em diferentes contextos no discurso dos frequentadores, sobretudo na forma das expressões "estar na Força", "sentir a Força" e "entrar na Força". A Força se caracterizaria como uma potência, ou para usar um termo caro a antropologia clássica, uma potencialidade mágico-religiosa, um estado tal que possibilitaria diferentes experiências através das possíveis realizações dessa potência latente.

O conceito de Força é recorrente em muitos hinos do santo daime desde os primeiros hinos recebidos por mestre Irineu. Gostaria de destacar a forma como o conceito é trabalhado no hino "Chamo a força" que pertence ao hinário denominado Hinos novos na doutrina do Alto Santo e Cruzeirinho junto ao grupo do CEFLURIS. Lembrando que o Santo Daime possui uma doutrina cantada onde os ensinamentos e os principais valores do grupo são transmitidos através dos hinos e, por essa razão, os hinários são considerados os pilares da doutrina daimista, sobretudo os hinos recebidos pelo fundador da doutrina.

Chamo a força, eu chamo a força

A força vem nos amostrar

Treme a terra e balanceia

E vós não sai do seu lugar

Treme a terra, Treme a terra

Treme a terra e geme o mar

Ainda tem gente que duvida

Do poder que vós me dá...

Como pode ser notado no trecho acima, a Força é evocada e juntamente com 
ela um mundo diferente passa a ser perceptível, a existir propriamente como experiência. A potência chamada passa a existir não apenas na pessoa que vive a experiência, mas também no novo mundo descortinado durante o ritual. $\mathrm{E}$ aos poucos a pessoa passa então a adentrar esse outro mundo sem, no entanto, sair deste, mantendose como diz o hino "no seu lugar".

A existência simultânea desses dois mundos, o ordinário e o Astral, não é algo que dependa da Força para ocorrer, mas dependemos da Força para experienciar essa coexistência. Esses dois mundos coexistem com ou sem a ação da Força, esta seria responsável, entre outras coisas, por colocar em evidência potencialidades desses mundos antes escamoteadas por um olhar desprevenido. Enquanto que de um lado a força nos permite acessar o astral, por outro permite que tenhamos uma perspectiva que passa a incluí-lo como lugar de onde se olha. $\mathrm{O}$ trecho a seguir retirado do hino "Confia", recebido por mestre Irineu e integrante do mesmo conjunto de hinos denominado Hinos novos ou Cruzeirinho, evidencia a característica do mundo astral em constituir-se como o outro lado, uma espécie de duplo do mundo ordinário:

\author{
Confia, confia, confia no poder \\ Confia no saber \\ Confia na força \\ Aonde pode ser
Esta força é muito simples
Todo mundo vê
Mas passa por ela \\ E não procura compreender
}

Estamos todos reunidos

Com nossa chave na mão

A limpar mentalidade

Para entrar neste salão

Este é o salão dourado

Do nosso pai verdadeiro 
Todos nós somos filhos

Todos nós somos herdeiros...

A chave de que o trecho fala seria a própria força que, entre outras coisas, permite o acesso ao salão dourado. A compreensão do astral como um lugar é trabalhada nesse hino através da ideia de se possuir uma chave para entrar em outro espaço, em outro lado. Nesse caso trata-se de visitar a própria morada do divino, de ir ao encontro do divino em outro lugar que não esse onde nos encontramos ordinariamente.

O astral constitui-se como um mundo paralelo onde os seres espirituais habitam e que o ritual, sobretudo através da bebida sacramental, tem como principal objetivo colocar os participantes em comunicação. A força é justamente a chave para que essa comunicação ocorra e encontra no daime um veículo privilegiado para sua realização. Nesses termos, o daime, entendido como um ser divino pela cosmologia do grupo pode também ser pensado através da definição elaborada por Marcel Mauss (2003) para a categoria mana:

Poder-se-ia dizer ainda, para exprimir melhor de que maneira o mundo da magia se sobrepõe ao outro [ordinário] sem separar-se dele, que tudo se passa como se ele estivesse construído numa quarta dimensão do espaço, cuja existência oculta seria expressa, por assim dizer, por uma noção como a de mana. (2003, p. 151).

A sobreposição de dimensões evidenciada por Mauss que a categoria mana teria como uma de suas atribuições, ou seja, realizar pontes ligando dois mundos, que apesar de possuir características distintas da força, sobretudo pelo fato de não possuir a característica distintiva de permitir o acesso de uma pessoa a outro mundo, pode ser utilizada como inspiração para se pensar a relação entre força e astral. A força, nesse caso, seria uma forma de manifestação oculta ou explícita desse mundo denominado astral e que o ritual teria como objetivo modular. Uma das características intrínsecas dessa força seria viabilizar o trânsito dos adeptos da doutrina daimista para esse outro lugar que se constitui como um mundo inseparável do mundo ordinário e, em outro sentido desse trânsito, bastante enfatizado pelo sistema umbandista, trazer as entidades e os seres de outro mundo para se manifestarem nesse mundo. 
O daime, do ponto de vista antropológico, seria o responsável por fornecer no plano metafísico a síntese dessa passagem, pois conteria em si a combinação da dimensão física e da força que emana do astral, constituindo assim uma potencialidade para o trânsito entre mundos que, em determinado momento do ritual, tornam-se um único mundo. A força latente presente na bebida, quando transferida a outro corpo torna-o sagrado, transferindo sua potencialidade e possibilitando que ele se manifeste no mundo astral e, de forma análoga, permitindo que os seres do outro mundo se manifestem nesse corpo sacralizado. A força é essa chave que, de forma análoga ao processo que transmuta a bebida de um chá para um ser divino, diviniza os corpos abrindo a passagem para essa outra dimensão do espaço. Passagem aqui assume um sentido não de caminho, mas sim de uma sobreposição que tenderia a uma unificação momentânea e passageira que tornaria a separação indiscernível.

É difícil conceber um trânsito onde se está na partida e no destino ao mesmo tempo, mas é exatamente disso que se trata experienciar um ritual que ocorre concomitantemente nesse plano da vida ordinária e no astral. Basicamente, entrar em contato com o astral não significa deixar de estar em contato com este mundo, mas, ao invés disso, trata-se antes de acessar um novo mundo que permitiria permutar-se a perspectiva em relação ao mundo habitual, mas sem abandoná-lo completamente.

Essa mudança de perspectiva que o acesso ao astral provoca é embasada em uma série de hinos daimistas que descrevem a capacidade que a bebida e a força têm em deslocar os participantes a outros lugares, coloca-los em contato com outros seres. Através de concepções como bebida professora, bastante presentes no discurso dos frequentadores, de onde surgem também relatos sobre novas formas de ver situações da vida cotidiana, é destacado o contato com uma nova perspectiva sobre o mundo que seria responsável por produzir um aprendizado por ter implicações permanentes na vida dos participantes. Essas implicações são mencionadas, sobretudo como o auxílio em encontrar alternativas para resolução de problemas pessoais, reavaliação de situações de contenda e de relações familiares, bem como na forma de insights de ordem mais geral. Essa mudança de olhar sobre a própria vida está intimamente ligada a uma mudança de abordagem em relação a concepções e pensamentos bastante condicionados pelo mundo ordinário, onde viveríamos e consequentemente estaríamos condicionados, pelo menos na maior parte do tempo. 
Estar em dois lugares ao mesmo tempo surge então como uma possibilidade que instiga a reflexão a respeito desse trânsito entre astral e mundo ordinário, sobretudo da relação entre a presença simultânea de uma pessoa em dois mundos e a relação disso com as incorporações. Foi justamente nesse trânsito entre mundos que ocasionalmente fui contemplado com minha primeira experiência classificada como uma incorporação em giras de umbanda com daime. Refiro-me a essa experiência como incorporação, sobretudo por entender que ela foi interpretada como tal no momento em que ocorreu e, de acordo com minha percepção acerca da compreensão de um médium, cheguei a essa classificação, porém discutirei mais adiante o contexto em que minha experiência se deu no ritual e a forma como encarei essa aproximação entre mundos.

Durante esse acontecimento eu participava de uma gira de umbanda com daime dedicada os Erês no mês de setembro de 2014, na igreja Flor da Montanha, em Lumiar/RJ. Essa igreja, contudo, não faz parte do campo declarado desta pesquisa que se limitou a alguns centros religiosos da cidade de São Paulo, apesar da igreja de Lumiar representar um pioneirismo bastante reconhecido pelos adeptos dos rituais que envolvem santo daime e umbanda. Porém tive o privilégio e a honra de participar de duas giras com daime junto a esse grupo que tiveram papel decisivo no desenrolar desta pesquisa.

Não me restam dúvidas de que rituais dessa ordem tendem a ser surpreendentes e transformadores de uma forma mais geral, porém isso ocorre numa perspectiva temporal em diferentes amplitudes. As experiências mais intensas tendem a serem cíclicas em sua intensidade, porém nunca replicadas, e com uma baixa frequência de repetições desses picos, pelo que pude constatar no decorrer de oito anos participando sazonalmente de rituais desse tipo.

Havia decidido há alguns anos visitar a Flor da Montanha para acompanhar uma gira com daime, porém só consegui participar efetivamente de um ritual nessa igreja em setembro de 2014. A Flor da Montanha é uma igreja que possui uma história bem particular, pois, entre outros fatores, tinha como liderança espiritual Mãe Gamo d'Oxum, carinhosamente conhecida como Baixinha pelos seus filhos e filhas de santo e integrantes do grupo religioso do qual estava à frente.

Baixinha era uma mãe de santo carioca que, entre outras coisas, foi responsável por firmar uma aliança com o Padrinho Sebastião Mota de Melo, o que proporcionou 
um intercâmbio intensivo entre um terreiro de umbanda carioca e os rituais de santo daime da comunidade amazônica do Céu do Mapiá, como bem tratado por Guimarães (1992) e posteriormente por Alves Júnior (2007). Ou seja, participar de um trabalho nesse terreiro era, para mim, acessar um capítulo importante da história do diálogo entre os dois sistemas religiosos.

Descrevo a seguir minha experiência de incorporação nesse terreiro, algo inédito desde que comecei a frequentar e posteriormente pesquisar em terreiros e igrejas de daime há oito anos e, ao mesmo tempo, inusitado, pelo fato dessa experiência ter ocorrido em um dos últimos rituais realizados pela Baixinha, antes de seu falecimento em novembro daquele mesmo ano.

Participava da gira no salão da igreja Flor da Montanha e estava nesse momento com os olhos fechados, porém esse estado foi interrompido por algo que chamou minha atenção. Tratava-se de uma melodia assoviada por alguém, cuja fonte produtora desse som se deslocava pelo ambiente e parava próxima ao lugar onde eu me encontrava. Aquele assovio se integrava de alguma forma a minha experiência e a modificava compondo-a de forma harmônica chegando a exercer até mesmo certo protagonismo sobre ela. Essa atração me fez virar até a fonte que produzia aquele assovio e a abrir os olhos, que até então estavam fechados. É nesse momento que noto que havia um médium incorporado que me fitava enquanto assoviava e, instantaneamente após eu notá-lo visualmente, ele começa a se deslocar em minha direção.

Naquele momento fui tomado por uma sensação de compreensão da situação. Entendi que havia uma conexão entre o que se manifestava no médium e o meu estado. O assovio foi uma manifestação que encontrou ressonância em mim, pois acredito que estávamos, nós dois, em estados muito similares, talvez tomados por uma força muito parecida. Foi então que, para minha surpresa, ele parou em minha frente e pegou em minha mão, conduzindo-me ao centro do salão.

Nesse momento apesar de estar em uma posição onde não gostaria de estar justamente por ter notado que não havia mais ninguém no centro do salão além do médium que me levou até lá e eu, assumi a postura de me abrir para a experiência como quem se abre para algo inédito, enfim, alguém que está disposto a surpreender-se. Uma das diretrizes que sempre havia procurado colocar em prática durante minha pesquisa e, 
sobretudo nos trabalhos de campo em rituais de umbanda com daime, foi justamente de tentar evitar situações como essa. Em contrapartida também sempre tive muita clareza na necessidade de me deixar ser conduzido pela experiência, assumindo uma postura de quem quer aprender de uma forma sincera. Foi isso que ocorreu nesse momento em que fui colocado na posição de um aprendiz por uma entidade espiritual.

Assim que cheguei ao centro do salão onde ocorria a gira recebi um passe da entidade que me conduzia, que consistiu basicamente de movimentos que a entidade fez com as mãos bem próximas ao meu corpo. A entidade circulava ao meu redor realizando essas manipulações quando, em determinado momento, parou e começou a estabelecer comunicação verbal comigo. A essa altura eu já tinha plena convicção de que algo inédito em termos de experiência mediúnica estava ocorrendo comigo. Sentia contrações em meu corpo, o que de certa forma contribuía para moldar minha postura corporal e minha expressão facial com certa rigidez, que ocorria acompanhado de minha plena consciência da transformação corporal a que estava imerso.

Enquanto a entidade falava comigo, discorrendo sobre o que seria o trabalho espiritual naquela casa e os principais valores que deveriam estar sempre no horizonte como o amor, a justiça, a paz e a harmonia, eu continuava com os olhos fechados ouvindo as orientações espirituais que eram dirigidas a mim, sobretudo à força que estava em mim e que também precisava receber instruções de uma conduta espiritual que deveria ser praticada naquele centro religioso. Foi nesse momento que a entidade toca delicadamente a palma de minha mão estendida e eu sou invadido por uma luz intensa, extremamente branca, que irradia de uma fonte difusa e que, mesmo estando de olhos fechados, tenho a experiência do espaço bem aguçada, mas trata-se de outro espaço, de outro ambiente, que me permite um deslocamento na direção dessa fonte luminosa até o momento em que não posso mais discernir o que é luz e o que não é. Noto que meu corpo nesse momento é o ancoradouro firme e sólido da experiência que, como uma árvore, lança suas raízes sobre um solo profundo ou um rochedo para garantir que suas folhas possam balançar suavemente ao capricho do vento.

Nesse momento tenho a impressão de ter atingido uma sintonia fina com a música, o canto e as palavras que a entidade à minha frente pronunciava. Apreciava e compreendia tudo como uma perfeita composição de elevado sentido do qual eu fazia parte, pois estaria também em ressonância com tudo que acontecia. Essa ressonância era 
composta de paradoxos como, por exemplo, o fato de quanto mais longe eu me projetava na experiência ou, para compartilhar da ontologia nativa, quanto mais eu adentrava no Astral, mais me aproximava do ritual no qual estava inserido e consequentemente mais reverberava em mim o discurso da entidade que me atendia.

Do que foi dito pela entidade, reproduzo um trecho que julgo imprescindível para a compreensão do que ocorria naquele momento. Momento esse em que eu estava submetido a uma experiência arrebatadora e lúcida, que permitiu a lembrança da seguinte fala: "Eu sei que não dá vontade de ir embora, mas nós temos que voltar. Nessa casa o tambor é a lei, e o tambor agora está tocando pra subida”.

Dito isso, fui conduzido até os atabaques num gesto executado pela entidade que ressaltava o que havia sido mencionado a pouco, ou seja, a importância de que a lei dos atabaques deveria ser seguida. Mas antes disso ela precisaria ser compreendida por mim e pela entidade que se manifestava em mim, coisas que eu não seria capaz de separar por serem elas mesmas inseparáveis nessa experiência. Fui colocado em uma posição bem próxima aos tambores para que não restasse qualquer dúvida de que o chamado e a subida das entidades eram regidos pelos mesmos, em outras palavras, eles conduziam esse processo e deveriam ser tomados como referência para o desencadeamento das ações de todos os seres engajados no ritual.

Estava claro que a entidade que se manifestava em mim estava sendo iniciada naquela casa, sobretudo pela apresentação de algumas diretrizes como as leis e os valores daquele centro através de outra entidade que depois tomei conhecimento tratarse do Caboclo Pena Branca. A experiência ocorreu concomitantemente em dois planos, fato esse que a própria entidade evidencia em sua fala. No momento em que o Caboclo Pena Branca diz: “... eu sei que não dá vontade de voltar, mas nós precisamos voltar...”, ele se dirigia à entidade espiritual que se manifestava em mim e que, oriunda desse mundo denominado Astral, estaria naquele momento se manifestando no plano da vida ordinária através daquele trabalho e deveria posteriormente "subir", ou seja, voltar para o mundo Astral através do toque dos tambores.

Ao mesmo tempo em que uma entidade do Astral se manifestava em mim, eu também estava em outro lugar. Percebi que a fala da entidade também poderia ser compreendida de outra perspectiva, pois confesso que sua interpretação a partir dessa situação passou a assumir essas duas possibilidades e, acima de tudo, a própria 
experiência naquele momento consistia nessas duas possibilidades imbricadas, ou seja, uma não separação, ou ausência de fronteiras nítidas, do par médium/entidade e tampouco do mundo ordinário/astral.

Eu estava no ritual e não estava. Ouvia as instruções do Caboclo Pena Branca e as compreendia muito bem. Elas faziam parte, assim como os sons dos atabaques e do canto, do lugar no qual eu me encontrava e que definitivamente era diferente do mundo ordinário. Durante essa experiência sentia a força do ritual propriamente dita, que emanava com mais intensidade naquela área central da gira, que me envolvia e arrebatava com sua potência.

O Caboclo Pena Branca ficou durante todo esse tempo ao meu lado, que não devem ter representado mais que alguns minutos, pronunciando alguns fundamentos do trabalho espiritual da casa e dessa forma conduzindo minha experiência. Isso durou até o momento em que ele tomou minhas mãos e me levou até os tambores, que eram os responsáveis por conduzir o ritual e constituíam o que foi denominado de "a lei do terreiro", no sentido de emanar deles a pulsação que orquestra as ações dos habitantes do plano terreno e do plano astral, imbricadas durante o ritual.

Fiz uma reverência aos tambores, demonstrando ter compreendido sua importância na cosmologia do grupo e ao mesmo tempo tentando entender o que esses instrumentos estavam dizendo naquele momento. O contexto demonstrava que o estado em que eu me encontrava deveria cessar, ou pelo menos ser atenuado, a partir daquele momento. Se minha incorporação continuasse eu não estaria levando a lei da casa à sério e isso poderia ser interpretado como uma atitude desrespeitosa. Isso me leva a concluir que, em última instância, eu deveria ter o controle sobre minha experiência, observando as leis do terreiro.

Voltei para o meu lugar tentando demonstrar algum controle sobre meu estado o que na verdade era uma tentativa frustrada, pois a experiência continuava rompante e qualquer tentativa de controlar meu estado era demasiado difícil. Realizava ali um esforço hercúleo para submeter minha experiência ao ritual, pois sabia que já havia saído dos parâmetros pelo simples fato de ter ocorrido uma experiência de incorporação num momento em que se cantava para a subida das entidades e, como se isso não bastasse, havia sido conduzido até o centro da gira e permanecido lá num momento em que não havia mais nenhum médium/entidade ocupando essa área. 
Diante do acontecimento de algo imprevisto que foge ligeiramente da sequência estabelecida pelo ritual, como foi essa experiência de incorporação num momento em que as entidades deveriam ir e não vir, mecanismos de rearranjo são colocados em ação para lidar com a excepcionalidade e retomar o bom andamento das coisas. Como se o bom andamento dependesse de um duplo controle, em instâncias diferentes, porém orquestradas em conjunto pela máquina ritual através da aproximação e do distanciamento do astral e consequentemente das próprias entidades.

Essa sequência de aproximações e distanciamentos realizada a cada ritual busca acima de tudo a manutenção de uma boa distância entre os dois mundos. A aproximação entre esses mundos que o ritual realiza, e que encontra na incorporação talvez sua expressão mais nítida, produz uma opacidade momentânea de suas fronteiras que não pode se estender para além do ritual, ainda que esses dois mundos coexistam o tempo todo.

A coexistência desses dois mundos muitas vezes é expressa através da tentativa de classificação do transe mediúnico como situado a meio caminho entre a experiência consciente e a inconsciente. Tal posicionamento sugere a existência de mundos não separados ou estanques, como se o fato de entrar em contato com outro mundo implicasse na ruptura, ainda que momentânea, das relações com esse mundo. A consciência enquanto processo contido na concepção de pessoa e responsável pela apreensão do mundo e de si mesmo existe para além dessas fronteiras sendo, sobretudo, modulada pela força que emana do astral, mas também pelas entidades que podem ser representadas como modulações dessa força.

A inconsciência seria, dessa forma, não uma ruptura com o mundo ordinário, mas, ao contrário, representaria um novo estado de conscientização ${ }^{47}$. Estar consciente de novas coisas a partir da experiência do astral representa muito mais um processo de transformação alimentado pela mudança de perspectiva resultante do diálogo entre dois mundos que por uma separação propriamente dita.

O fato de a consciência ser percebida como um processo suscetível a inúmeras variações, porém persistente enquanto fenômeno de apreensão do mundo possui implicações em outras esferas além das experiências de transe mediúnico e, de acordo

\footnotetext{
${ }^{47}$ Para uma discussão crítica acerca das antigas noções de estados alterados de consciência ver Mercante (2012).
} 
com o relato do pai de santo Jorge Scritori, pode ser percebida em situações como a que ele próprio vivenciou durante um estado de coma.

\footnotetext{
.... Eu fiquei trinta dias em coma, num quadro que o médico entendia que eu estava tetraplégico e se voltasse do coma, [ficaria em] estado vegetativo. Então quando a gente fala em transe existe um mito muito grande... é consciente, é inconsciente, é semiconsciente. Como uma pessoa que já entrou em coma eu entendo que a inconsciência total, ela não existe [...]Porque da minha experiência de coma eu tenho lembranças nítidas...
}

As reflexões sobre a própria abrangência da consciência são habitualmente acionadas para se falar sobre a diferença entre o transe da umbanda e o transe do santo daime, sobretudo entre os sacerdotes responsáveis pelos rituais que, de formas diferentes, chamam a atenção para a complexidade das experiências dessa ordem, descartando, no geral, polarizações e oposições com base em categorias estanques. Jorge Scritori ressalta que para se atingir o transe sem o uso do daime o processo envolvido é mais difícil, pois, segundo ele, para se desenvolver a passividade necessária para conseguir se entregar a uma experiência dessa ordem é preciso confrontar-se com sólidas barreiras impostas pelo nosso modelo social.

Gê Marques questiona a concepção do voo xamânico entendida como a viagem a outros mundos como algo restrito a xamãs e considera que existe uma tendência em colocar esse tipo de transe em oposição a outras experiências como as incorporações, em que ao invés de se visitar outros mundos seriam seres de outros mundos que visitariam o corpo do praticante. Ele define a miração como uma experiência sem nenhuma manifestação física, enquanto que a incorporação se manifestaria no corpo, porém sua fala incita a reflexão sobre a existência de um vasto espectro entre esses estados abarcando inúmeras possibilidades de combinações entre eles.

O desenvolvimento mediúnico consiste basicamente em um processo onde o adepto aprende a controlar seu transe e a conhecer as forças envolvidas nesse tipo de trabalho espiritual. Controlar o transe nesse contexto significa realizar uma modulação na força manipulada pelo ritual que, caso contrário, devido a sua intensidade pode facilmente imprimir rumos indesejáveis nas experiências individuais quando acessada por pessoas inexperientes. $\mathrm{O}$ fato de uma pessoa tomar o daime, que pode proporcionar uma experiência de transe intensa, não significa que essa pessoa terá acessado o astral, 
tampouco vivido uma experiência mediúnica.

Jorge afirma que existem muitos daimistas, ou seja, que já tem experiências de transe em rituais do santo daime, mas que chegam ao terreiro sem ter a mediunidade desenvolvida. O desenvolvimento mediúnico nas giras de umbanda com daime envolve um processo de aprendizado e controle definido de uma forma bastante sofisticada por Jorge:

[...] É como se a mediunidade fosse a porta que num primeiro momento está fechada e o santo daime fosse a chave. Então ele se torna o que? O próprio desenvolvimento mediúnico tem essa proposta de abrir a porta. O santo daime, pelas suas propriedades, abre essa porta rápido. Ele abre essa porta de uma vez.

Essa abertura abrupta ao outro lado, ou seja, ao mundo astral, que o daime possibilita, tende a realizar um movimento de ruptura mais pronunciada que quando esse acesso é feito através de um processo de desenvolvimento mediúnico que se realiza gradativamente. Esse acesso repentino ao outro lado pode desencadear situações em que a perda do controle sobre a experiência por parte dos adeptos torna-se evidente podendo até assemelhar-se, em alguns casos, ao transe repentino que incide sobre indivíduos despreparados e que realizam seu primeiro contato com o transe, que no candomblé denomina-se também como santo bruto.

Não creio tratar-se do mesmo fenômeno, obviamente. O que costuma chamarse de santo bruto está diretamente relacionado a um fenômeno de incorporação em que o orixá demonstra possuir uma relação com determina pessoa e isso muitas vezes pode significar a necessidade de se realizar a iniciação daquele indivíduo, ou seja, lapidar ou fazer o santo daquela pessoa e, dessa forma, modular a força que se manifesta numa tentativa quase sempre bem sucedida de controla-la.

Nas giras com daime as manifestações de incorporação necessitam de um desenvolvimento do médium para ocorrer. Esse processo pode vir acompanhado de instruções de outros médiuns e/ou entidades, mas no geral depende muito mais da pessoa que pretende se desenvolver. Trata-se de adquirir a capacidade de exercer uma modulação sobre a força que se manifesta, mas ao mesmo tempo de corresponder corporalmente a ela.

Em todos os terreiros visitados durante a pesquisa, bem como na igreja de santo daime, não encontrei ritos iniciáticos específicos para as giras de umbanda com 
daime. A iniciação nesses rituais é atrelada à ideia do desenvolvimento mediúnico que ocorre através de um processo onde o controle da experiência é um dos principais objetivos, conforme descrito por Gê Marques:

[...] Não existe uma iniciação como na umbanda, uma camarinha, aonde a pessoa vai lá e fica lá[...]mas existe o processo de desenvolvimento mediúnico em que a pessoa vai se capacitando, entrando em contato com a força, vai conseguindo dominar mais a força. E depois de um tempo começa a incorporar, depois começa entrar em contato com seus caboclos, vai sabendo seu nome, vai aprendendo lidar com aquilo. Até o momento que é autorizada a atender. Isso não quer dizer que o desenvolvimento terminou.

É digno de observação o fato do processo de iniciação ser sempre incompleto, ou seja, o controle da força e as aproximações com o astral operam com uma boa parcela de imprevisíveis, ou seja, fenômenos que tendem a escapar do controle e, portanto, estão sujeitos a reveses permanentemente. Essa instabilidade inerente a esse tipo de experiência está relacionada primeiramente ao fato da força, apesar de aceitar e operar bem em certos níveis de modulação controlada, é uma potência arredia por excelência que, através de descontroles sazonais, mantêm a sua essência transformadora.

O desenvolvimento mediúnico seria então saber lidar com esses imprevisíveis da força e os respectivos descontroles que eles acarretam. O descontrole, caso construíssemos um espectro entre controle e descontrole, seria uma manifestação mais próxima do bruto, tomando de empréstimo a terminologia aplicada ao candomblé, porém com significado e implicações bastante diversas. O bruto aqui designa aquilo que escapa ao controle, mas ao contrário do candomblé, não se trata de uma experiência imatura, mas uma constante no seio da maturidade e, talvez por isso mesmo, represente uma forma de conduzir a experiência e de produzir um tipo de conhecimento através do inesperado. Em outras palavras, trata-se de um aprendizado transformador justamente por ter como natureza o estado de fuga constante das sucessivas tentativas de enquadramento através do controle do transe.

Portanto, se a iniciação representa o controle da incorporação e, de forma mais geral do transe, o desenvolvimento mediúnico é um processo sempre inacabado e o médium jamais atingirá o controle pleno da experiência. Desse modo, talvez o ponto chave do processo de iniciação resida justamente em compreender a natureza instável e 
em estado de permanente negociação existente na relação entre mundo ordinário e astral, cuja potência transformadora que resulta dessa aproximação manifesta na força sua essência não controlável.

Isso nos leva a um deslocamento de fronteira no que diz respeito à inserção do antropólogo. Recai agora sobre o antropólogo a necessidade de controlar a própria experiência do transe, visto que é vetada a participação nos rituais para quem não se dispõe a comungar o enteógeno. $\mathrm{O}$ antropólogo se depara com a necessidade de controlar a experiência para realizar a observação, ou seja, se submeter ao processo de desenvolvimento mediúnico, como apontado por Gê Marques. 


\section{Conclusão}

A partir dos dados apresentados pretende-se buscar um possível arranjo em que o material possa ser disposto, porém sempre com a possiblidade de novas configurações. Não está se buscando, dessa forma, uma conclusão da pesquisa propriamente dita, mas ao contrário, abre-se uma trilha analítica nas matas da religião que representa não o melhor e tampouco o mais bem marcado caminho, mas apenas uma trilha fina e discreta de existência insistente entre a floresta e a metrópole.

Pretende-se neste momento demonstrar a partir da análise de uma manifestação religiosa que se situa na intersecção entre dois sistemas religiosos, que apesar do sincretismo estar sujeito a uma grande variação de manifestações apreensíveis, uma lógica coerente e de certa forma recorrente pode ser identificada em diferentes sistemas religiosos. Nos sistemas religiosos aqui tratados podem ser identificadas versões de uma forma de relação do cosmo mais abrangente e que possuem zonas de transformação e produção de conhecimento em diferentes planos no ritual.

Através da análise do espaço ritual buscou-se uma abordagem que levasse em conta duas formas distintas de concepções de espaço na realização das giras com daime. Tais concepções representam diferentes transformações resultantes do diálogo dos dois sistemas religiosos abordados nesse estudo que conforme se pretendeu demonstrar, ocorre de formas distintas dependendo da perspectiva que é assumida.

O sistema religioso que se reproduz através da realização de ritos transforma-se à medida que passa a dialogar com outro sistema religioso. Esse diálogo não representa uma anexação do outro, mas, ao contrário, uma transformação ontológica que o sistema passa a consolidar através de suas práticas rituais. Destaca-se, dessa forma, a maneira como essas transformações ocorreram de forma análoga no terreiro e na igreja, sobretudo quando nos atentamos às estruturas de reprodução das práticas rituais no espaço.

Nas práticas rituais encontradas nas giras de umbanda com daime ressalta-se de que maneira, através de sucessivos ritos de aproximação e afastamento entre mundo astral e mundo terreno, essas práticas buscam justamente o estabelecimento de uma zona de transformação em que os elementos que compõe o ritual passam a não operar mais ao mundo astral ou ao mundo terreno, mas assumem um duplo pertencimento. 
Essa aproximação entre os dois mundos que foi obtida através de uma série de práticas e ritos que ocorrem durante o ritual tende a amenizar-se gradativamente até que possa se estabelecer uma boa distância entre eles ao término do ritual.

Dessa forma pretendeu-se demonstrar como a aproximação entre mundo astral e mundo terreno possibilita transformações ontológicas no plano das práticas rituais e que encontra de certa forma, analogia com o diálogo que ocorre entre as Linhas das entidades invocadas onde se evidenciou a existência de uma transição entre elas que também pode ser lida na chave da transformação de uma Linha em outra.

A abertura das Linhas pode ser apreendida como a possibilidade de se circular entre as diversas linhas chamadas durante o ritual através das zonas liminares entre uma linha e outra que podem ser representadas por entidades que pertencem simultaneamente a duas linhas ou, de outro ponto de vista, pode-se abordar a abertura das linhas como uma abertura do próprio panteão, muito bem representada pela doutrinação de Tranca-rua realizada por Ogum Beira-mar através do aparelho de Padrinho Sebastião. A transformação ontológica decorrente dessa abertura do santo daime para as entidades afro-brasileiras não ocorre, porém sem que o Exu aceite beber o daime, ou seja, ele mesmo precisa ser antes transformado para só então passar a integrar o panteão.

Esse princípio ontológico transformador também se fez presente na discussão sobre o transe como uma experiência situada entre mundos. Não se tratando dessa forma de uma experiência que proporciona o deslocamento do participante para outro mundo ou ainda a recepção do outro em sim mesmo. Trata-se de uma experiência que não é situada nem no mundo terreno e tampouco no mundo astral, mas, ao mesmo tempo ocorre simultaneamente nos dois mundos. Dessa forma, chama-se atenção justamente para o lugar da experiência do transe que ocorre em um entre lugar, em uma zona de transformação que, entre outras coisas, é o lugar privilegiado para a produção do conhecimento sobre si e sobre o outro sendo, nesse caso, a Boca da Mata um princípio ontológico constitutivo da noção de pessoa do grupo. 
Bibliografia

ALVERGA, Alex Polari de. Viagem ao Santo Daime: o livro das mirações. RJ, Rocco, 1984.

BASTIDE, Roger. As Religiões Africanas no Brasil. São Paulo, Pioneira-Edusp, 1989. Estudos Afro-brasileiros. São Paulo, Ed. Perspectiva, 1983.

. Imagens do Nordeste Místico em Branco e Preto. Rio de Janeiro, O Cruzeiro, 1945.

BROWN, Diana. “Uma História da Umbanda no Rio”. In: ISER (org.). Umbanda e Política. Rio de Janeiro, Iser-Marco Zero, 1985.

CAMARGO, Cândido Procópio Ferreira de. Kardecismo e Umbanda. São Paulo, Pioneira-Edusp, 1961.

CONCONE, Maria Helena Villa Boas. Umbanda: Uma Religião Brasileira. São Paulo, CER-FFLCH/USP [col. Religião e Sociedade Brasileira, vol.4], 1987.

COUTO, Fernando de La Rocque. Santos e Xamãs: estudo do uso ritualizado da ayahuasca por caboclos da amazônia e, em particular, no que concerne sua utilização sócio-terapêutica na doutrina do Santo Daime. Brasília, UnB, 1988, tese de mestrado.

DANTAS, Beatriz G. Vovó nagô e papai branco: usos e abusos da África no Brasil. Rio de Janeiro: Graal, 1988.

ELIADE, Mircea. O xamanismo e as técnicas arcaicas do êxtase. São Paulo, Martins Editora, 1998.

FAVRET-SAADA, Jeanne. “Ser afetado”. In: Revista Cadernos de campo n. 13: 155$161,2005$.

FERRETTI, Sergio F. Repensando o Sincretismo. São Paulo. EDUSP/Arché editora, 2013.

GEERTZ, Clifford. A interpretação das culturas. Rio de Janeiro: ed. Guanabara,1982. GOldMAn, Marcio. A Possessão e a Construção Ritual da Pessoa no Candomblé Dissertação de Mestrado em Antropologia Social. Universidade Federal do Rio de Janeiro, UFRJ, Brasil. Ano de Obtenção: 1984.

GOULART, Sandra Lúcia. As raízes culturais do santo daime. Dissertação de mestrado em antropologia social. Universidade de São Paulo. FFLCH-USP. São Paulo, 
1996.

Contrastes e Continuidades em uma Tradição Amazõnica: As

Religiões da Ayahuasca. Tese de Doutorado em Antropologia Social. IFCHUNICAMP. Campinas, 2004.

GREENFIELD, Sydnei M. “The Reinterpretation of Africa: Convergence and Syncretism in Brazilian Candomblé”. In GREENFIELD, Sydnei M. \& DROOGERS, André. Reinventing Religions: Syncretism and transformation in Africa and the Americas. Rowman \& Littlefield Publishers. 2001.

GUimarães, Maria Beatriz Lisboa. A "Lua Branca" de Seu Tupinambá e de Mestre Irineu: Estudo de Caso de Um Terreiro de Umbanda. Dissertação de mestrado em Ciências Sociais, UFRJ, 1992.

LABATE, Beatriz Caiuby e ARAUJO, Wladimiyr (orgs.). O uso ritual da Ayahuasca. Campinas, SP: Mercado de Letras; São Paulo: Fapesp, 2002.

A reinvenção do uso da ayahuasca nos centros urbanos. Campinas: Mercado de Letras: FAPESP, 2004.

LABATE, B.C., Santos, R.G., Anderson, B., Mercante, M., Barbosa, P.C.R. “Considerações sobre o tratamento da dependência por meio da ayahuasca". Núcleo de Estudos Interdisciplinares sobre Psicoativos (NEIP), 2009. Disponível em: www.neip.info.

.ROSE, I. S. ; SANTOS, R. G. . Religiões ayahuasqueiras: um balanço bibliográfico. 1. ed. Campinas: Mercado de Letras, 2008.

LA ROQUE COUTO, Fernando de. Santos e Xamãs. Dissertação de mestrado em Antropologia Social, UNB, Brasília, 1989.

LÉVI-STRAUSS, Claude. L'homme nu. Plon. Paris, 1971.

MACRAE, Edward J. B. N. Guiado pela Lua: Xamanismo e uso ritual da Ayahuasca no culto do Santo Daime. São Paulo: Editora Brasiliense, 1992.

El Santo Daime y la Espiritualidad Brasileña. 1. ed. Quito: Ediones Abya_Yala, 2000.

MARQUES JUNIOR, Antonio Alves. Tambores para a Rainha da Floresta: a inserção da Umbanda no Santo Daime. Tese de mestrado em Ciência da Religião, PUC-SP, 2007. 
O encontro da Umbanda com o Santo Daime. $26^{\mathrm{a}}$ Reunião Brasileira de Antropologia - Grupo de Trabalho Substâncias Psicoativas: Cultura e Política, 2008, Porto Seguro - BA. Anais da $26^{a}$ Reunião Brasileira de Antropologia. Distrito Federal: Associação Brasileira de Antropologia, 2008.

MAUSS, Marcel. Sociologia e Antropologia. São Paulo. Cosac Naify, 2003.

MERCANTE, M. S. .Ayahuasca, Imaginação, Saúde e Doença na Barquinha. Rio de Janeiro: Editora Fiocruz, 2012.

MONTEIRO, Clodomir da Silva, "O uso ritual da ayahuasca e o reencontro de duas tradições. A miração e a incorporação no culto do santo Daime”, In: LABATE, Beatriz Caiuby e ARAUJO, Wladimiyr (orgs.), O uso ritual da ayahuasca, São Paulo: Mercado de Letras, 2002, p. 413-444.

MOREIRA, Paulo; MACRAE, Edward J. B. N. Eu venho de longe: Mestre Irineu e seus companheiros. Salvador: Editora da Universidade Federal da Bahia - EDUFBA, 2011.

NEGRÃO, Lísias. Entre a cruz e a encruzilhada: formação do campo umbandista em São Paulo. São Paulo, Edusp, 1996.

ORTIZ, Renato. A morte branca do feiticeiro negro. São Paulo: Brasiliense, 1991.

POLARI, Alex. O guia da floresta. Rio de Janeiro. Record/Nova Era.1992.

ROSE, Isabel Santana de; SANTOS, Rafael Guimarães dos e LABATE, Beatriz Caiuby. "Panorama da bibliografia sobre as religiões ayahuasqueiras". 26a Reunião Brasileira de Antropologia - Grupo de Trabalho Substâncias Psicoativas: Cultura e Política, 2008, Porto Seguro - BA. Anais da $26^{\mathrm{a}}$ Reunião Brasileira de Antropologia. Distrito Federal: Associação Brasileira de Antropologia, 2008.

ROSE, Isabel Santana de. Espiritualidade, terapia e cura. Um estudo sobre a expressão da experiência no Santo Daime. Dissertação de Mestrado em Antropologia Social, Universidade Federal de Santa Catarina, Florianópolis, 2005.

SILVA, Vagner Gonçalves da. Candomblé e Umbanda - Caminhos da Devoção Brasileira. São Paulo: Ática, 1994.

O Antropólogo e sua Magia. São Paulo: EDUSP, 2006.

VELHO, Yvonne Maggie Alves. Guerra de orixá: Um Estudo de Ritual e Conflito. Rio de Janeiro, Zahar, 1975. 